
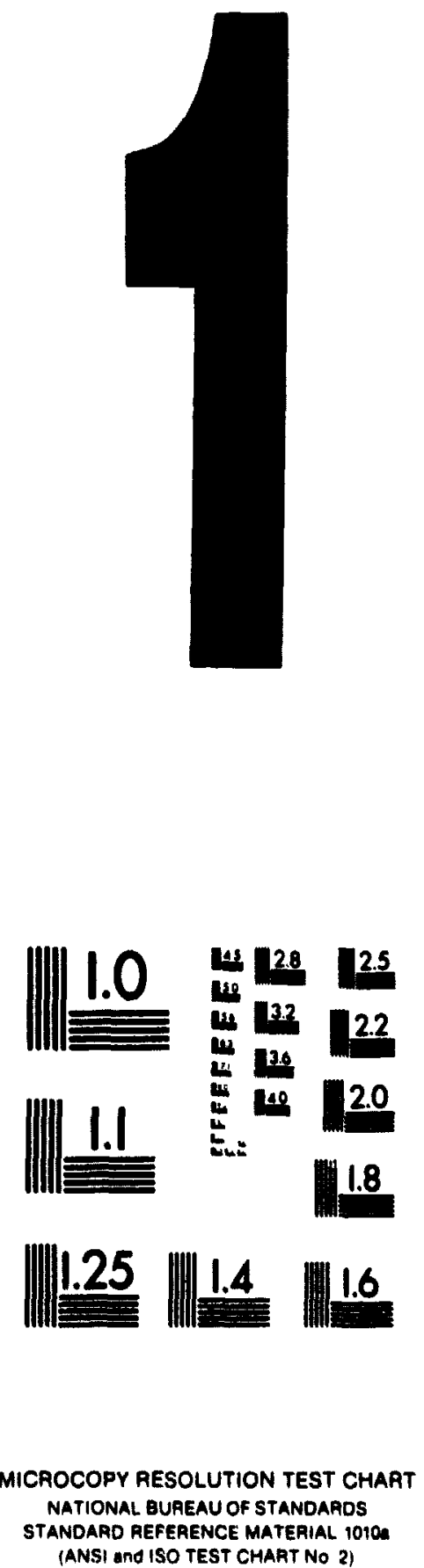
National Library

of Canada

Canadian Theses Service

Onome cenede

K1A ONA

\section{Brbliotheque nationale}

du Canada

\section{Service des theses canadiennes}

NOTICE

The quality of this microform is heavily dependent upon the quality of the original thesis submitted for microfilming. Every effort has been made to ensure the highest quality of reproduction possible.

If pages are missing, contact the university which granted the degree.

Some pages may have indistinct print especially if the original pages were typed with a poor typewriter ribbon or it the university sent us an inferior photocopy.

Reproduction in full or in part of this microform is governed by the Canadian Copyright ACt, R.S.C. 1970, C. C-30, and subsequent amendments.

\begin{abstract}
AVIS
La qualité de cette microforme dépend grandement de la qualité de la thèse soumise au microfilmage. Nous avons tout tait pour assurer une qualité supérieure de reproduction.

Sil manque des pages, veuillez communiquer avec Puniversité qui a contéré le grade.

La qualité d'impression de centaines pages peut laisser à désirer, surtout si ies pages originales ont été dactylogra. phiées à laide d'un ruban usé ou si luniversité nous a fait parvenir une photocopie de qualité inférieure.
\end{abstract}

La reproduction, méme partielle, de cefte microforme est soumise a la Lol canadienne sur le droit d'auteur, SRC 1970, c. C-30, et ses amendements subséquents. 
THE PRESENTATION OF NEWS ON CBC TELEVISION, 1953-1988

\author{
by \\ ROSEMARY BERGERON, B.J. \\ A thesis submitted to \\ the Faculty of Graduate studies and Research \\ in partial fulfilment of \\ the requirements for the degree of \\ Master of Arts \\ in Canadian studies
}
Carleton University
OTTAWA, Ontario

May 7, 1990

(c) copyright

1990, Rosemary Bergeron 
National Library

of Canada

Canadian Theses Service

Bibliotheque nationale du Canada

Service des theses canadiennes

Ottawa. Canada

KIA ON4

The author has granted an irrevocable nonexclusive licence allowing the National Library of Canada to reproduce, loan, distribute or sell copies of his/her thesis by any means and in any form or format, making this thesis avalable to interested persons.

The author retains ownership of the copyright in his/her thesis. Neither the thesis nor substantial extracts from it may be printed or otherwise reproduced without his/her permission.
L'auteur a accordé une licence irrévocable et non exclusive permettant à la Bibliotheque nationale du Canada de reproduire, preter, distribuer ou vendre des copies de sa these de quelque maniere et sous quelque forme que ce soit pour mettre des exemplaires de cette thèse à la disposition des personnes intéressées.

L'auteur conserve la propriété du droit d'auteur qui protège sa these. Ni la these ni des extraits substantiels de celle-ci ne doivent etre imprimés ou autrement reproduits sans son autorisation. 
The undersigned recommend to the Faculty of Graduate Studies and Research acceptance of the thesis

"The Presentation of News on CBC Television, 1953-1988"

submitted by Rosemary Bergeron, Hons. B.J.

in partial fulfilment of the requirements for

the degree of Master of Arts

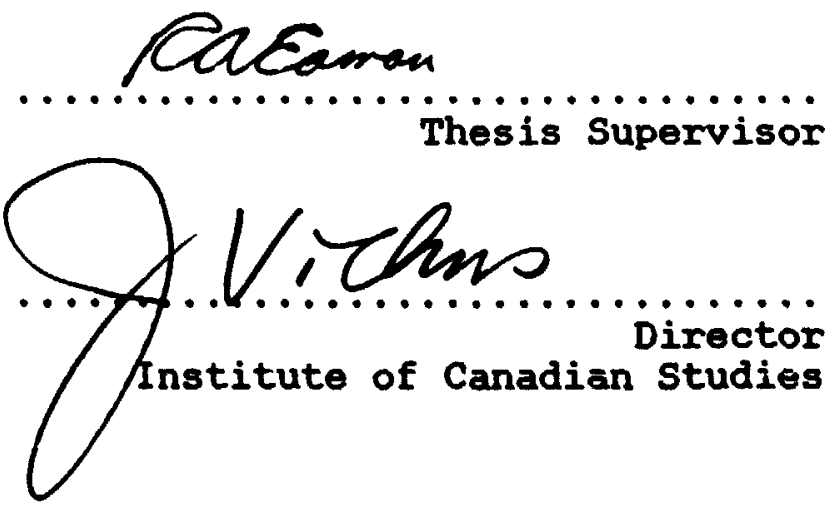

Carleton University

Ottawa, Ontario

May 1990 


\section{ABSTRACT}

This study examines the development of presentation styles in television news programs produced by the Canadian Broadcasting Corporation from 1953 to 1988 , to assess significant developments in television news and the cause of such changes. It attempts to isolate various factors which shape television news, notably the impact of news gathering technology and decision-making by journalists.

The study is carried out in the context of a provisional set of time frames marking different stages of development. The provisional periodization is used to chart the extent to which television news has developed its own story-reporting methr i, rather than merely borrowing presentation styles from the print media, newsreels and radio. The usefulness of the provisional periodization is tested by means of the detailed analysis of 996 news stories in $72 \mathrm{CBC}$ newscasts. The news reports are analyzed according to such presentation elements as story subjects, the use of interview clips, the use of film and videotape, and the role of the anchor and reporter. 
THE PRESENTATION OF NEWS ON CBC TELEVISION FROM 1953 TO 1988 TABLE OF CONTENTS

Abstract ... . . . . . . . . . . . . . . . ii Table of Contents . . . . . . . . . . . . . . . iil List of Tables . . . . . . . . . . . . . . . . iv List of Figures . . . . . . . . . . . . . . . . . vi Introduction . . . . . . . . . . . . . . . . . 1 Chapter 1 A Provisional Periodization of the Development of CBC Television News . . . . . . . . 7

Chapter 2 Making Choices: Story Subjects and PseudoEvents . . . . . . . . . . . . . 28

Chapter 3 Accessing Voices: Who Gets to speak on the News? .. . . . . . . . . . . . 49 Chapter 4 Film, Video and Graphics: Story-Telling Tools or Attention-Getters? . . . . . . . 73 Chapter 5 The Roles of the Anchor and Reporter . . 102 Chapter 6 The Television News Story as a Genre: From Mirror to Mediation . . . . . . . . 135 Conclusion. . . . . . . . . . . . . . . . . . 155 Bibliography. . . . . . . . . . . . . . . . . 168 


\section{LIST OF TABLES}

1. News stories Coded by Subject, 1956-1988 . . . . . 33

2. Stories about political subjects . . . . . . . 34

3. Stories about Canadian Politics . . . . . . . 35

4. Political stories Focused on the Political Process . . . . . . . . . . . . . . . 37

5. Stories about Spontaneously-occurring Events . . . 43

6. Use of Interview clips . . . . . . . . . . . 53

7. Types of Interviews in Newscasts, 1956-1988 . . . 54

8. Interviews of Canadian Politicians . . . . . . . 55

9. Interviews of Non-Canadian Politicians . . . . . . 56

10. Stories that Include Reporters Questioning Interviewees . . . . . . . . . . . . . 58

11. Stories with No Attribution or Interviews . . . . 62

12. Types of Attribution in Newscasts, 1956-1988 . . 65

13. Stories with No Graphics, Film or video . . . . 75

14. Stories with No Graphics . . . . . . . . . . 76

15. Use of Film or Video . . . . . . . . . . . 76

16. Stories Using Film/Video of Talking Heads . . . 79

17. Stories Using Spontaneous Film/Video . . . . . . 80

18. Stories Using Silustrative Film/Video . . . . . 82

19. Types of Graphics in Newscasts, 1956-1988 . . . . 84

20. Stories Showing Anchors on Screen or Doing Volceover . . . . . . . . . . . . . 104 
21. Stories with Anchor on screen for at Least Part of the

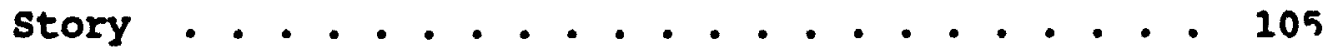

22. Stories with Voiceover by Anchor . . . . . . . 105

23. Stories with Anchor on Screen for Entire story . 107

24. Stories Showing CBC Reporters on Screen or Doing voiceover . . . . . . . . . . . . . 110

25. Stories Showing CBC Reporters on Screen . . . . . 111

26. Stories with Voiceover by CBC Reporters . . . . . 112

27. Stories for which No Source Indicated . . . . . 115

28. Stories Identified in Newscasts as CBC Stories . . 116

29. Stories Showing CBC Reporters in the studio . . . 119

30. Stories Showing СBC Reporters in the Field . . . 121

31. Basic Report3 . . . . . . . . . . . . . . 338

32. Eyewitness Reports . . . . . . . . . . . 140

33. Inferential Reports . . . . . . . . . . . . 148 


\section{LIST OF FIGURES}

1. Provisional Periodization... . . . . . . 155

2. Revised Periodization . . . . . . . . . . 158 


\section{INTRODUCTION}

The blitz of information that is the television

newscast, with its drama of unresolved conflict, sometimes startling visuals and quick pace, is constantly changing as the events reported also change. Even though the news changes each day, television presents news in a standardized form, making the television newscast significant both as a form of television and as a form of journalism. This study examines the development of presentation styles in television news programs produced by the Canadian Broadcasting Corporation from 1953 to 1988.

It has been argued that presentation styles set. television news apart from the surrounding television programs which compete with news for the viewer's attention. According to Justin Lewis, "the news is made up of a whole series of stylistic conventions that shape and structure the news so that we immediately distinguish it from other forms of television." 1

The standardized form of the television newscast helps the viewer to make sense not only of the rush of information and chaotic happenings of the world but also to do so in the context of the multiple messages throughout the television broadcast schedule. Peter Dahlgren has written:

1. Justin Lewis, "Decoding Television News," in eds. P. Drummond and $R$. Paterson, Television in Transition, (London: British Film Institute, 1985), 223. 
[The] production conventions of the [program], with their repetitive narrative structures, limited repertoire of verbal and visual symbols, [standardized] dramatic motifs, and thematic contents, create an easily graspable and unambiguous "Image world".?

This study analyzes changes over time in CBC television news presentation style, to measure the extent to which they can be explained by attitudes about television news held by news workers such as reporters, editors and managers, by the medium's role as a provider of entertainment and information and by technology.

This thesis does not argue that technology is the strongest factor determining television news presentation style, but seeks to develop a better understanding of the role technology has played. Apart from highly specialized articles in technical journals, little information has been published on the history of television news technology. If technological determinism is considered a too simplistic explanation for the development of television news presentation, there is nonetheless a need to identify those aspects of television news that can be satisfactorily explained by technology. It may be that the choice of whether to use an available technology is rooted in the

2. Peter Dahlgren, "The Modes of Reception: For a Hermeneutics of TV News," in Television in Transition, Ibid. 238. 
organizations. Broadcasting institutions, as loci of power in society, may themselves broadcast news programs that perpetuate the social order. Graham knight has defined news as a type of knowledge that tends to reproduce, in an uncritical fashion, relations of power and domination in society. ${ }^{3}$ This reproduction is structurally determined because journalists use conventional forms and methods of news reporting. In knight's analysis, therefore, news cannot be a critical, coherent and couprehensive representation of reality. Ironically, efforts by television news to seem more real and thus more authentic by such means as interview clips and emphasis on the roles of anchors and reporters con increase the degree to which the information on the newscast is mediated or shaped for the viewer.

Ideology implicit in news values may be acting to shape television news and ideological content may very well be a consequence of presentation style, but this study does not attempt to examine the role of ideology. Such an evaluation would require not only detailed content analysis of the ideas expressed in news stories, but also a study of the values in Canadian society and their development over time.

3. Graham Knight, "News and Ideology," Canadian Journal of communication, 8 (No. 4, September 1982), 15-41. 
Whethar these changes have affected the role of television news in society is not immediately clear. It may be that Knight's definition applies to television news at all stages of its development. This study does not offer definitive explanations for television news presentation style and its development over time, but it seeks to identify the extent to which technical, administrative and other factors have operated at a various periods in the history of CBC television news.

Any effort to explain the presentation style of CBC television news must at present take place without the help of a comprehensive history of the CBC, its television news service, institutional and economic structure, technological capabilities and programing. No such history has been written, but this study, drawing upon elements of social science and history, attempts to contribute to the small but growing body of work on various aspects of the CBC's development.

Information about CBC television news department operations, CBC news programs and news personalities over the years appear in Knowlton Nash's two-volume autoblography, in books by television broadcasters Peter Trueman and Warner Troyer, and in general histories of Canadian television by Sandy stewart and E. Austin Weir, but such works tend to be anecdotal rather than scholarly. The 
few studies that have been done on the institutional

structure of the CBC, such as The public Eye: Teleyision and the Politics of Canadian Broadcasting, 1952-1968, by Frank Peers, make little attempt to relate institutional or administrative history to the CBC's television programs. When broadcasters write their memoirs, they fondly recall the pioneering development of methods to combine silent visuals, voiceover and sound-on-film interviews, for example, using complicated but ingenious multiple-projector systems. The overwhelming sense they give, however, is that television news now is undoubtedly better, more technically sophisticated, more immediate, with more expertise on the part of the reporters, more in-depth stories and more catchy visuals.

But the theory of television news in general and most bosks and articles about Canadian television news treat the news as a static entity. This makes it difficult to assess significant developments in television news and the cause of such changes." without an ... orical perspective, the theoretical analysis of television news risks being mired in presentism, a too-narrow concentration on the present with

4. The work of theorists such as John Fiske, John Hartley, Gaye Tuchman, Peter Dahlgren, Justin Lewis, Robert Rutherford Smith, Graham Knight, Gertrude Robinson and Steven Kline, for example, concentrates on present-day television news. 
too little reference to the past or the future, as critics find in television news. In The Yedia Society, Ross A. Eaman writes:

We cannot, in fact, understand what news is simply by examining it in its present form. We need to know how news today differs from news a century or more ago. Otherwise, we run the risk of mistaking attributes of news that are merely temporary for those that are universal.5

One of the most visible indicators of change in television news presentation style over time is technology. This study tracks changes in CBC television newscasts in relation to developments in technology. When technology cannot explain a shift in presentation style or there is little change despite developments in technology, it is probable that other forces are at work, such as the attitudes news workers have about their roles and the choices a news organization makes. Some aspects of presentation style, notably the on-camera roles of anchors and reporters, do not change drastically over time. This study examines technological factors governing how anchors and reporters are shown on television news, but looks at such other factors as CBC's attitudes about journalism and its labour-management relations for fuller explanations.

5. Ross A. Eaman, The Media Society: Bestc Irsues and controversies, (Toronto: Butterworths, 1987), 33. 
CHAPTER 1: A PROVISIONAL PERIODIZATION OF THE DEVELOPLENT OF CBC TELEVISION NEWS

In order to analyze the nature and significance of the changes that have taken place in CBC television news, this study uses a provisional set of time frames marking different stages of development. In broad terms, technology and journalistic conventions such as the role of reporters and anchors are factors used to differentiate the provisional periods of television news development at the CBC. The broad time frames are used to chart the extent to which television news has developed its own story-reporting methods, such as the use of film and graphics, on-camera reporters, and interviews with people in the news. The time frames are based on a preliminary screening of CBC television news programs from 1953 to 1988 , to identify obvious changes in presentation style. Descriptions of television news formats in the biographies of Canadian broadcasters, CBC television schedules, newspaper clippings, anecdotal histories of Canadian television and oral history interviews of Canadian television journalists have also provided a basis for the definition of the provisional periods.

The provisional time periods group key factors expected to cause change. At the conclusion, the provisional time periods will be reassessed in view of the analysis of a 
representative sample of $\mathrm{CBC}$ television newscasts. The provisional periods define developmental boundaries that represent periods of the greatest change in television news style and seek to explain this change.

\section{Period One: Gestation (1952-1954)}

For the first couple of years of CBC television, the network's news service struggled to provide news items for television programs. It seemed to lack a sure sense of television news as either a unique form of television program or of journalism. It was a period when audiences, intrigued by the new medium, could be expected to find even dull programs entertaining.

Broadcasters were experimenting with television news, trying to determine the most appropriate form it should take. In a 1950 article in Journalism Ouarterly, Harry $E$. Heath Jr. described different ways American broadcasters were considering to present the news on television. 6 The methods then in use on American television were: remote (outside the studio) coverage; national or local newsreel programs; newscasts consisting solely of still pictures with volceover narration; headline shows; television

"newspapers"; and ticker tape programs. Headline programs

6. Harry $\mathrm{E}$. Heath Jr. "News by Television: A Review of Practices and Possibilities," Journalism Quarterly, 27 (Fall 1950), 404-418. 
consisted of a series of brief news bulletins with text of their headlines on screen and volceover by a news reater. News programs consisting of film of spot news done by studio remotes or outside broadcasts were most popular with viewers. Least popular were ticker-tape programs. They presented text of the temperature, time, and the weather forecast on the screen. The news was printed in a horizontal band running from right to left across the screen or scrolling up the screen. This style survives in the form of cable television news and program schedule chanrels.

As dull as some of the formats seem in hindsight, they were practical ways for cash-strapped television news operations to get onto the air. In fact, broadcasters put news on the air mostly to gain prestige. Television news was decades away from being a money maker.

In the 1950s, television news struggled for credibility as a journalistic form. In an assessment of the state of television news in the 1950s, Sig Mickelson stated that critics "talk in terms of television as a hybrid monstrosity derived from newspapers, radio news and the newsreels, which inherited none of the merits of its ancestors." 7

If the CBC was uncertain about the importance of news on television and the way it should be presented, the radio 
newscast and the theatre newsreel provided models for the broadcasting of news and its pictorial presentation. The newsreels typically shown to motion plcture audiences were noteworthy for fast-paced volceover and editing of the standard fare of scenes of aviation daredevils, beauty contests and propagandistic war footage. The newsreels were dogged by a reputation for being entertaining but journalistically suspect. They provided audiences in pretelevision days with visuals of people and places in the news, but did not supplant newspapers and radio news. The CBC's radio news service, by contrast, won respect from the time of its establishment in 1941. By 1952, when CBC television went on the air, the radio news service had a team of experienced broadcast journalists reporting for regularly-scheduled daily national, regional and local newscasts.

Preoccupied, perhaps, with the technical demands of the new medium of television, $C B C$ television did not immediately schedule television news as a distinct program in a time slot of its own, in the same way that CBC radio provided daily newscasts. CBC television news during this early period made little more than a token appearance, giving audiences grainy visuals of primarily show-and-tell soft news stories rather than the hard news stories now customary on television newscasts. The capacity to provide daily 
pictorial news reports was the one aspect of the new medium that gave television an advantage over newspapers, radio and newsreels. There were no on-camera reporters, 11kely because the theatre newsreel had not used any, but also because the CBC initially saw its role as a disseminator of news gathered by print and radio. Getting news film on the air was a feat in itself, making the task of obtaining clips of interviewees all the more difficult and thus all the more rare.

When the television service of the CBC first went on the air, the programs most resembling newscasts were a weekly half-hour program entitled "Newsmagazine" and a biweekly television newsreel program, "CBC Newsreel", with French and English editions. The first listing for "CBC Newsreel" appeared in the CBC's program guide, CBC Times, on September 11, 1952, from 8 to $8: 15$ p.m. The listing for September 22, 1952 briefly explained that the program consisted of international, national and local news. CBC cameramen filmed stories in Montreal and Toronto. The CBC relied on freelancers to film stories elsewhere in Canada and other organizations such as Gaumont and the British Broadcasting Corporation for film of international events. "CBC Newsreel" lasted only for several months. No recordings of "CBC Newsreel" are known to exist, but an extensive collection of "Newsmagazine" fllms have survived, 
starting with the september 14, 1952 edition. It looks very much like the movie newsreels that were fust going out of fashion as television broadcasting began. It consists of a number of short 1tems, mixing hard news and some lighthearted human interest features, all with music and an everpresent voiceover narration which sounds ponderous to present-day ears. Until 1957, the program largely retained this newsreel format, providing viewers with a wide range of visuals, with little attempt at in-depth coverage of the hard news issues of the period.

Heath pointed out that the main disadvantage of such newsreel programs was their lack of timeliness in relation to other types of programs. News programs using only a news anchor or still pictures could get a news item on the air much faster than it took to film and edit a news story for a newsreel program.

Gordon sinclair announced the start of a new CBC television news program, one that would use an anchor reading news stories as well as filmed items, in his radio and television column in The Toronte star:

CBIT is streamlining its early evening stuff from Monday on, with the idea of inserting a news slot. TV News, up to now, has been slightly more desirable than a migraine headache, but not much. No show I have seen has been much brighter than dishwater. . . There will be interviews that shape up in advance a bit dullish, atill pictures, and the holp of assorted experts. Anything but that ireary news reading given by WBEN [a Buffalo 
television atation]. ${ }^{8}$

The program about which sinclair wrote was "Tabloid", a half-hour mix of news, weather, interviews and light entertainment, broadcast Monday to Saturday from Toronto. The news, lasting approximately 10 minutes, appeared at the beginning of the program. There are only three recordings of "Tabloid" that include the news, for February 27, March 18 and March 31, 1953. The February 27 recording is apparently a rehearsal program, perhaps a preview for Sinclair and his fellow television critics, since it predates "Tabloid's" first broadcast on March 9, 1953.

Gunnar Rugheimer, ther, the CBC's television news manager, was in charge of the newscast on "Tabloid". In an article in CBC Times, Rugheimer explained that he and his staff of four editors selected news film from 12 to 15 stories each day, usually keeping each story to a maximum length of between one minute and one minute forty-five seconds. The CBC obtained news footage from freelance photographers in cities across canada and elsewhere in the world, from United Press, the BBC and the Canadian armed forces. Transporting the film from the locations of the

8. Gordon Sinclair, "Radio and Television," The Toronto Star, February 28, 1953, 5.

9. "Tabloid: Daily Actualities on CBC-TV," CBC Times, (July 5-11, 1953), 3-4. 
storles and between the stations of the CBC's limited network depended largely on air and ground transportation. As the CBC added stations to its inaugural service in Montreal and Toronto, the microwave network permitting the station-to-station transmission of broadcast signals was gradually extended. It was only in 1958 that coast-to-coast microwave service went into operation, with the addition of St. John's, Newfoundland in 1959. In the 1950s, the only way to get film from overseas was by air, meaning that Ilimed stories from overseas were several days old before Canadians got to see them. Examination of the film used on "Tabloid" and "Newsmagazine" reveals that news stories of the Gestation Period tended to depict events simply, using few edits, shots or changes of camera angle, confining stories to the role of an eyewitness. This suggests that the sheer effort involved in obtaining timely news film left little time for the development of more complex film narrative styles and prompted the CBC to rely on coverage of preplanned events such as news conferences and army training exercises filmed by the Canadian Army. The "Tabloid" newscasts had simple studio settings. The February 27 program shows anchor Gil Christie reading the news while seated at a desk on which there is a large microphone and a telephone. A television monitor mounted in the wall over his shoulder is apparently just for decoration as it is 
never used in the newscast. On the March 18 and March 31 editions of "Tabloid", Christie delivers the nowscast while standing up, script in hand. A clock on the wall behind him is the only feature of the set. One camera ls used in the programs, only varying the distance of the straight-ahead shot of Christie.

Like "Newsmagazine", the "Tabloid" newscasts reveal little attempt at innovative presentation. There are only two instances in which "Tabloid" departs from the standard use of a news anchor on-camera or doing voiceover to film. The February 27 program uses several still photographs with the anchor's voiceover, interspersed with shots of Christie reading the news items. The March 31 program shows the anchor answering the telephone on his desk during the newscast, intently listening, and then imparting the details of the late-breaking story to the viewers. The "Tabloid" recordings suggest that the CBC television news presentation style during the 1952 to 1954 period was based on making do with the limited technology, no doubt failing to impress critics such as Gordon sinclair, rather than experimenting with a variety of formats. 
Period Two: Legitimation and Experimentation (1954-1966)

The provisional periodization used in this study identifies 1954 as the beginning of a new stage in the development of the CBC television news service because it was in that year that the CBC began broadcasting a daily television newscast recognizable by today's standards as a newscast, with filmed stories and an anchor shown reading the news from a studio. The CBC's experience with "Tabloid" 1llustrated that neither the producers of news nor the producers of light information and entertainment shows such as "Tabloid" were satisfied with the inclusion of newscasts in other types of programs. This was largely because the news producers wanted more air time for the news. The CBC began broadcasting an 11 p.m. newseast on May 31, 1954. The newscast began as a 10-minute program, increasing to 15 minutes by september of 1954. The early-evening news was removed from "Tabloid" and given its own 6:45 to $7 \mathrm{p} . \mathrm{m}$. place in the schedule on December 28, 1954. This indicated a commitment on the part of the CBC to the development of newscasts as separate television programs. As of January 1956, the CBC news service was putting out 13 daily newscasts for television, including national and regional editions. 
During this period, the CBC continued work on the setting up of the transmission system needed to gather and broadcast news film. The CBC concentrated 1ts efforts on improving ways of tilming news, particularly with actuality sound, and of quickly getting the film from the location of the story to the television studio. The completion of the const-to-coast microwave relay system was important to the reporting of breaking news storles and the live transmission of network news specials. The launch of trans-Atlantic satellites in 1962 and 1965 gave television news producers a means of transmitting international news that was faster than the transport of film by aircraft. The CBC's pioneering television reporters, many from the print media and others from CBC Radio, were learning how to handle technological demands of television news. This study hypothesizes that the first generation of canadian television fournalists felt they could win professional credibility only by using the same kinds of journalistic tools used in radio and print. This meant that showing viewers visuals of events and people in the news was not considered sufficient. If television news was to be taken seriously as a form of journalism able to compete with radio and print, it had to report on the same range of hard nows subjects. It also had to place the information in a context 
for viewers, using source attribution and interviews both to enable viewers to assess the reliablifty of the information and to distance the CBC from opinions expressed. In the 1954 to 1966 perlod, the role of the reporter and anchor became more defined. The CBC restricted its television news anchors to being news readers, in order to preserve the anchors' reputation for objectivity. It conceded, however, that the anchor had an important role in inspiring viewer confidence, and had the same news anchor read the daily newscast rather than using several anchors on a rotating basis. As film recording and transmission technology improved, it became easier for newscasts to incorporate filmed reports by reporters on location. Television news thus further distanced itself from the style of the theatre newsreels, which relied on cameramen to shoot the stories and on strident narrators to tell the stories, never shsking a reporter. The technology made it possible for newscasts of the 1954 to 1966 period to show reporters with increasing frequency. The increase in the number of news stories showing CBC television reporters may be only partly due to an improved technological capacity to show their reports on the air. By showing more CBC reporters, the CBC was beginning to admit that its television service was gathering news and not merely translating into television news style stories already reported by newspapers and radio. Although 
reporters were getting a more visible role on CBC television, the manner in which they presented news stories is expected to have remained descriptive rather than analytical or interpretive. The increased use of reporters and filmed news storles, as well as improved technology, suggests that the newscasts would begin to cover more subject areas and use more interview clips by different people in the news.

Period Three: Expansion (1966-1980)

The next period of development in this provisional periodization starts in 1966. In that year, the CBC began to reorganize the format of its television news programs in response to criticism by CBC journalists and media critics. They felt that although the network's television news service provided reliable reporting, the presentation of the news was dull and uninspired. There was also a feeling that the roles of anchors and reporters needed to be expanded. Anchors and reporters belonged to different unions, which jealously protected exclusive spheres of responsibility for their members. Anchors were not allowed to write the stories they read on the air or to go out in the field to gather news. Reporters were not allowed to serve as news anchors. 
$A$ CBC reporter became the anchor of the national 11 p.m. newscast in an effort to give the news more credibility than that ostensibly provided by news anchors, who only read the news and did not play a part in reporting it. During this period, there was an effort to develop a team of specialist reporters in such fields as science and labour. In addition, the $C B C$ began to place correspondents reporting for the national network news in different cities in Canada. The development of a team of specialist reporters and regionally-based network correspondents was designed to lessen the concentration of the newscast on political news, particularly reports of federal events occurring in ottawa. If the proposed reforms were effective, the newscasts of the perioà should be characterized by greater use of visuals, making use of the domestic communications satellite launched in Canada in 1972. In addition, subject specialization by reporters and the establishment of a team of network reporters in the regions should have contributed to a greater range of story subjects. With efforts to get more CBC reporters into the field, it is expected that television news became less reliant on news supplied by other organizations and better able to cover breaking news stories. 
Period Four: Maturation (1980-1988)

This provisional period is expected to indicate change in the presentation style of CBC television newscasts because the network was beginning to make the transition from shooting news on film to videotape, which required less processing time and less cumbersome recording equipment. The number of communications satellites increased, making it easier to provide news footage. It is also expected that videotape made television news stories better able to cover breaking news stories and less dependent on pre-scheduled events. In the 1980s, the $\mathrm{CBC}$ began to call its anchors "chief correspondents", which suggests a broadening of the role of news anchors, to allow them to do more reporting and interviewing. During this period the CBC also gave more air time to news backgrounders and analysis. Analysis of $C B C$ television newscasts for the 1980-1988 period is expected to show that reporters began to do more interpretation of the news, rather than simply acting as eyewitnesses.

This study examines 996 news stories in 72 CBC television newscasts from 1956 to 1988 in order to assess the nature and degree of change that has occurred within the provisional periodization. The sample of CBC television newscasts analyzed in this study in effect selected itself for the period prior to 1978. The CBC did not keep a 
comprehensive collection of recordings of complete newscasts until 1978.

The study does not include the gestation period of 1952 to 1954 in the statistical analysis of CBC television news to 1988 because there are only three "Tabloid" newscasts to represent the manner in which the CBC presented daily news. Hence, the first period does not appear on the statistical charts. References to "Tabloid" in the text are intended to provide a general basis for comparison with the study findings for the other provisional periods.

The "Tabloid" programs, two broadcasts from the "CBC Television News" from 1956 and 1957, and 24 newscasts from 1960 to 1966 in the study sample are the only complete newscasts known to exist for the period before 1969. There are only four examples of the national network late-evening newscast, called the "CBC National News" in 1969 and renamed "The National" in 1970. Because of the small. number of ners programs preserved on film or videotape, the sample also includes a random selection of six newscasts aired as part of the series "Weekday" in 1969 and 1970, and of 16 newscasts that were part of the CBC network news and current affairs series "Weekend", also in 1969 and 1970. The newscasts of March 19, 1974, November 20, 1975, January 14, 1977 and May 19, 1977 are the only complete national network 
newscasts from 1971 to 1977. It is thus not possible to assemble a collection of recordings based on principles of statistical probability. The CBC and the National Archives of Canada have recordings of almost all editions of "The National" since 1978, from which an additional 16 programs are analyzed. Also included are a 1988 program from the weekly supper-hour network newscast, the "CBC News Saturday Report" and one from the $10 \mathrm{p} . \mathrm{m}$. weekly network newscast, the "CBC News sunday Report", also from 1988. Because it is not possible to obtain the same number of newscasts for each provisional period, the sample is random when a number of newscasts exist. The selection includes programs for different days of the week and different times of the year, to take into account possible variations in news content and presentation style due to less-heavy weekend or summertime news periods. With the exception of the 1950 s newscasts and the Toronto-area news program "Weekday", all newscasts in the sample are netw $k$ newscasts, to reduce possible variations in presentation, resources and style in CBC regional and local newscasts. "Tablold" was broadcast only in the Montreal, ottawa and Toronto regions, the only areas receiving CBC television signals in 1953. The "CBC Television News" broadcasts of 1956 and 1957 were shown only in ontario. They were broadcast from 6:45 to $7 \mathrm{p} . \mathrm{m}$. on 
weeknights. The sample of newscasts between 1960 and 1966 Includes examples of both the early evening edition of the "CBC Television News" and the national edition, broadcast at 11 p.m.

This sample includes different news programs from various periods of time in order to examine if change can be attributed to the different aims and formats of the programs. The "CBC Television News", "CBC National News" and "The National" are standard newscasts in their own time slots, reporting a variety of stories. "Weekend", "Weekday" and "CBC News Sunday Report" amalgamate newscasts and other program components, although only the newscast portion of the programs are analyzed in this study.

In the case of "Weekend", like "Tabloid", there were conflicts between the producers of the news portions of the programs and the people responsible for the current affairs or light information content, particularly over the amount of air time allotted to each segment. When "Weekend" went on the air in the fall of 1969, it incorporated the network's Saturday and Sunday 11 p.m. newscasts. The Saturday $11 \mathrm{p} . \mathrm{m}$. news returned to its separate time slot upon the cancellation of the Saturday "Weekend" edition in the winter of 1970. The sunday late-evening news remained part of "Weekend" until the fall of 1970, when it returned 
to the sole control of the CBC news department and regained its identity as "The National". The sample includer. three editions of "The National" that followed "Weekend" programs in september and october of 1970. On the september 27 and October 4, 1970 programs the news is titled "The National", but it is introduced as the "Weekend National" and the "Weekend" hosts sign-off after it. "Weekend", thereafter solely a current affairs program, remained on the CBC schedule until 1973.

"Weekday" was broadcast from 6:31 to 7:30 p.m. Monday to Friday in the Toronto area only. It replaced the network supper-hour newscast that the CBC stopped producing in June of 1969. "Weekday" featured a mix of national, international and local news, weather, sports, current affairs interviews and documentaries, and was on the air from the fall of 1969 to 1974.

The "CBC News Saturday Report" first broadcast in 1982 , is the most recent in a line of saturday network newscasts broadcast from 6 to $6: 30 \mathrm{p} . \mathrm{m}$., replacing the "saturday Evening News". It incorporates news reports from the previous week, with emphasis on stories prepared for the regions.

The "CBC News Sunday Report", broadcast from 10 to 10:25 p.m., began on October 13, 1985. The CBC program 
schedule described it at that time as a "program tailored to feature Peter Mansbridge at the things he does best -- news anchor, interview and host." ${ }^{10}$ The program differs from a standard newscast in that it includes interviews and a regular panel discussion. Mansbridge hosted a similar program of the same title from 1982 to 1985 , broadcast from 5 to $5: 30 \mathrm{p} . \mathrm{m}$. Before the program moved to $10 \mathrm{p.m}$., the CBC also broadcast a sunday-evening edition of "The National", at $11 \mathrm{p.m}$.

The sample is divided into groups according to programs and provisional periods of development. The analysis groups the "CBC Television News" broadcasts of 1956 and 1957 and 1960 to 1966, to represent the second period covering 1954 to 1966. The next period, up to 1980 , is represented by "Weekend", "Weekday", the "CBC National News" and "The National" programs broadcast in 1969 and 1970, as well as "The National" newscasts from 1974 to 1979. The sample studied for the fourth and final period consists of "CBC News Saturday Report" and "CBC News Sunday Report" programs broadcast in March of 1988 and "The National" between 1980 and 1988 .

10. CBC Television Advance Program Information, (No. 328 , october 12-19, 1985), 4. 
This study examines the content of the newscasts first in terms of the components of news stories, such as the use of interviews and attribution, story subjects, the coverage of preplanned or spontaneous events, and the use of film and graphics. The categories are designed to assess the development of television news as a narrative or journalistic form and the extent to which the use of storytelling tools such as interviews and film inserts are dependont on the evolution of technology. Secondly, it analyzes the stories in terms of the roles of anchors and reporters. 
CHAPTER 2: MAKING CHOICES -- STORY SUBJECTS AND PSEUDOEVENTS

To begin examining the historical development of CBC television news, this chapter looks at two aspects of how television has defined information as news: the choice of subjects reported and the degree to which news events are spontaneous or planned. The range of story subjects and their spontaneity are significant because they indicate the extent to which television news reflects reality.

People in the news business have tended to favour the theory of news as an unmediated reflection of reality, in effect downplaying the extent to which news stories are the result of choices made by editors, producers, reporters and other news workers. At the same time, moreover, the range of choices available to news workers is determined in part by the extent to which people who carry out activities deemed newsworthy, such as news conferences and carefullyorchestrated political leadership campaigns, plan such events with media coverage in mind. But academics such as Graham knight have written that the limited repertoire of story subjects considered newsworthy by all news media routinizes the news:

strikes, crime, and politics, in particular, have been standard news fare since the permanent advent of the daily press in the last century. This stability pinpoints something of a contradiction whose ideological value is important. While 
controversy and extraordinariness may be the principle ways in which newsworthiness is defined, the concrete types of controversial or extraordinary event that conetitute news copy are themselves routine and predictable."

Based on the supposition that the subjects of news stories are indicators of newsworthiness, this study codes the news stories in the sample in order to determine if there has been a change over time in the range of subjects covered by television news. The selection of events for coverage on television is governed by a complex set of factors: the traditional and routine areas of subject interest of the press that Graham Knight describes; the subjects customarily covered by other forms of the news media, such as radio and the theatrical newsreel; and changes in the values of society.

stories are coded under the following subjects: politics; military news; crime and the law; disasters and accidents; human interest; natural resources; science and health; the economy; labour; sports; social justice; the arts; industry; religion and education. Political stories include those about the political process and the work of politicians and legislatures, on the international, national, regional and local levels. International political stories include those about the United Nations,

11. Knight, op. cit., 27-28. 
the North Atlantic Treaty Organization and other international political organizations such as the Commonwealth. The category is defined broadly, coding a news report about a government's education policy under politics rather than education. A story about an IsraeliEgyptian ceasefire is coded as political when it concerns the activities of politicians or governments negotiating for peace.

This is not intended to be an exhaustive study of the presence of political content in television news, there being broader interpretations of politics that could be considered. The political category is not designed to pay specific attention to the development since the 19508 of quasi-governmental or political entities such as regulatory boards and groups created by government legislation such as the National Action Committee for the status of Women. Such development points to changes in the structure of political action in society and, with more players on the political field, it is reasonable to expect an increase in the coverage of political stories on television news. Since the subject category is designed to track the range of different story subjects covered, the interpretation of what makes a story political is confined to the activities of politicians and legislatures, a definition which includes the work of government-appointed bodies without making specific 
reference to them.

Military subjects are defined as armed conflicts between nations and between warring groups within nations. The crime category includes otories about the justice system. Upbeat or offbeat stories about ordinary people and their activities, leisure activities and other items about Iffestyles are coded as human interest. To take into account presumed changes in socletal values over time, the social justice category measures the occurrence of stories about such issues as human rights, desegregation, apartheid, and the living conditions on Indian reserves and in prisons. A greater awareness of the environment and the need to protect it is another measure of changing values in society. stories about pollution and other environmental issues are included in the natural resources category.

This study considers two hypotheses. First, if the newsreel, with its emphasis on visual interest and entertainment, has served as an influence on television news, then the activities of important people, notably politicians, should appear frequently as the subject of television news. Television news lineups should be characterized by human interest stories and sensational storles about crime and war. Secondly, if there has been a broadening of the subjects judged to be worthy of news coverage, there should be an increase in coverage of the 
arte, religion, education, science, health, and labour unions, subjecte traditionally given scant attention in the newe media. 12

Taking the period from 1956 to 1988 as a whole, this study found that only a limited number of story subjects are likely to be reported and that the general range of subjects has changed little over time (see Table 1). Storles about politics invariably cone itute the largest percentage of any single subject, both in terms of the number of stories and their liuration. Taken individually, the other subjects each colstitute 1 ess than 12 percent of the total number of stories and less than 10 percent of the duration of the newscasts. Stories about the economy, industry, natural resources, science and health, labour, sports, social justice, the arts, religion and education show particularly low results, tending to fall below five percent of the durations of the sample periods.

12. Research conducted for the National Archives of Canada exhibition "Beyond the Printed Word: Newsreel and Broadcast Reporting in Canada" uncovered gaps in newsreel and radio news coverage of twentieth century history that are surprising in view of present-day news values. The Depression of the 19308 , labour union unrest, the conscription crisis during the Second World War, the Gouzenko spy revelations of 1945 , and the 1956 Pipeline debate are events that would be headline news today, but such events seem to have recelved little or no mention, if one can judge by surviving newsreels and radio news recordings. 
TABLE 1

NEWS STORIES CODED BY SUBJECT, 1956-1988

\begin{tabular}{|c|c|c|}
\hline SUBJECT & STORIES & $\begin{array}{l}\text { \& OF TOTAL } \\
\text { DURATION }\end{array}$ \\
\hline Politics & $40.7(406)$ & 46.8 \\
\hline Military & 11.5 (115) & 8.2 \\
\hline Crime/Law & $10.0(100)$ & 8.2 \\
\hline Disasters/Accidents & $9.7(97)$ & 7.1 \\
\hline Human Interest & $5.3(53)$ & 4.7 \\
\hline Natural Resources & $2.4(24)$ & 3.8 \\
\hline Science/Health & $2.4(26)$ & 3.6 \\
\hline Economy & $4.5(45)$ & 3.5 \\
\hline Labour & $3.2(34)$ & 3.0 \\
\hline Sports & 2.7 (27) & 2.7 \\
\hline Social Justice & $1.9(20)$ & 2.2 \\
\hline Arts & $1.8(18)$ & 1.7 \\
\hline Industry & $1.2(12)$ & 1.5 \\
\hline Religion & $1.3(13)$ & 1.1 \\
\hline Education & $0.57(6)$ & 1.0 \\
\hline
\end{tabular}

Numbers in parentheses indicate the number of stories.

Some of the above percentages have varied, however, over the time period examined. The results show a fairly consistent increase in the number 0 duration devoted to political stories (see Table 2). 
TABLE 2

STORIES ABOUT POLITICAL SUBJECTS

\begin{tabular}{|c|c|c|c|}
\hline \multicolumn{2}{|c|}{ PERIOD/SAMPLE } & $\begin{array}{l}\text { \& OF NUMBER } \\
\text { OF STORIES }\end{array}$ & \multirow{2}{*}{$\begin{array}{l}\text { \%F TOTAL } \\
\text { DURATION } \\
\begin{array}{l}i 1.3 \\
52.6\end{array}\end{array}$} \\
\hline II & $\begin{array}{l}1956-57 \\
1960-66\end{array}$ & $\begin{array}{ll}40.6 & (13) \\
42.1 & (123)\end{array}$ & \\
\hline III & $\begin{array}{l}1969-70 a \\
1969-70 b \\
1974-79\end{array}$ & $\begin{array}{ll}31.6 & (88) \\
43.7 & (28) \\
52.8 & (47)\end{array}$ & $\begin{array}{l}36.2 \\
45.5 \\
49.0\end{array}$ \\
\hline IV & $\begin{array}{l}1980-88 \\
1988 c\end{array}$ & $\begin{array}{ll}41.2 & (85) \\
62.8 & (22)\end{array}$ & $\begin{array}{l}46.0 \\
77.5\end{array}$ \\
\hline
\end{tabular}

a = "Weekday" and "Weekend".

$b=$ "CBC Television News" and "The National".

$c$ = "CBC News Saturday Report" and "CBC News sunday Report". The numbers in parentheses are the number of stories in this coding category per time period. The "a", "b" and " $c$ " references are repeated only in the first chart in each chapter.

News reports about politics account for only one-fifth of the duration of "Tabloid" stories. The percentage of newscast time devoted to political stories doubles in the 1956 and 1957 newscasts, and increases to more than 50 percent during the 1960 to 1966 newscasts. The increase during the 1960 to 1966 period can be explained by the establishment by the early 1960 s of CBC parliamentary correspondents covering events in the House of Commons and the admission of broadcast journalists to the Parliamentary Press Gallery. The relatively stable percentage of political stories in the "CBC National News" and "The National" from 1969 to 1988 indicates consensus by CBC news 
producers that political reporting is a legitimate and important part of the CBC's role. The panel discussion about politics on "CBC News Sunday Report" accounts for the largest percentage of political stories, during the "CBC News Saturday Report" and "CBC News sunday Report" programs. There is evidence of an increase during the second provisional period, from 1956 to 1966 , in the number of stories and time devoted to news reports about Canadian politics (see Table 3).

TABLE 3

STORIES ABOUT CANADIAN POLITICS

\begin{tabular}{|c|c|c|c|}
\hline \multicolumn{2}{|c|}{ PERIOD/SAMPIE } & $\begin{array}{l}\text { \% OF NUMBER } \\
\text { OF STORIES }\end{array}$ & $\begin{array}{l}\text { \& OF TOTAL } \\
\text { DURATION }\end{array}$ \\
\hline II & $\begin{array}{l}1956-57 \\
1960-66\end{array}$ & $\begin{array}{ll}12.5 & (4) \\
20.8 & (61)\end{array}$ & $\begin{array}{l}10.2 \\
32.5\end{array}$ \\
\hline III & $\begin{array}{l}1969-70 a \\
1969-70 b \\
1974-79\end{array}$ & $\begin{array}{ll}17.9 & (50) \\
23.4 & (15) \\
33.7 & (30)\end{array}$ & $\begin{array}{l}27.8 \\
26.1 \\
36.9\end{array}$ \\
\hline IV & $\begin{array}{l}1980-88 \\
1988 \mathrm{C}\end{array}$ & $\begin{array}{ll}26.6 & (55) \\
28.5 & (10)\end{array}$ & $\begin{array}{l}32.5 \\
48.4\end{array}$ \\
\hline
\end{tabular}

Less than two percent of the duration of stories in the "Tabloid" programs is about Canadian politics. Mirroring the statistics on political stories in general, large increases occur during the second provisional period between the 1950 s newscasts and the 1960 to 1966 period, and during the fourth provisional period during the "CBC News saturday 
Report" and "CBC News sunday Report" programs.

Political stories in the 1950 s tend to be about nonCanadian subjects such as activities at the United Nations. But starting in the 1960s, more political stories are Canadian than non-canadian. The percentage of stories about Canadian politics does not increase markedly during the 1974 to 1979 period, even though television in the House of Commons began in 1977, providing television with a steady supply of visuals of House of Commons proceedings. The pattern of news stories about canada, regardless of subject, shows gradual increase. This helps to explain why newscasts report more stories about Canadian politics over time. Political stories are further subdivided to determine the extent to which they are about the political process itself or about government policy, for example, on the environment, the economy or the arts. stories about elections, political parties, leadership conventions and other elements of the political process constitute the single largest category of political story (see Table 4). 
TABLE 4

POLITICAL STORIES FOCUSED ON THE POLITICAL PROCESS

\begin{tabular}{clccc}
\hline PERIOD/SAMPLE & $\begin{array}{l}\text { \% OF NUMBER } \\
\text { OF STORIES }\end{array}$ & $\begin{array}{l}\text { \% OF TOTAL } \\
\text { DURATION }\end{array}$ & $\begin{array}{l}\text { \% OF ALL } \\
\text { POLITICAL } \\
\text { STORIES }\end{array}$ \\
\hline \multirow{2}{*}{ II } & $1956-57$ & $23.0(3)$ & 7.3 & 17.6 \\
& $1960-66$ & $55.0(68)$ & 28.5 & 52.6 \\
\multirow{2}{*}{ III } & $1969-70 a$ & $43.1(38)$ & 17.6 & 48.5 \\
& $1969-70 b$ & $32.1(9)$ & 18.3 & 40.2 \\
& $1974-79$ & $38.2(18)$ & 21.9 & 44.6 \\
\multirow{2}{*}{ IV } & $1980-88$ & $51.7(44)$ & 26.0 & 56.5 \\
& $1988 c$ & $27.2(6)$ & 34.2 & 44.0 \\
\hline
\end{tabular}

${ }_{1}^{1}$ Percentage of total story duration in each sample period. ${ }^{2}$ Percentage of all political stories in each sample period.

The table indicates some fluctuation over time in terms of the number of stories and percentage of total duration, but the duration of political stories is at least forty percent, tripling between the 1956 to 1957 and 1960 to 1966 periods. The increase during the second provisional period likely occurs because of the 1961 Commonwealth Conference, the 1963 federal election, the Gerda Munsinger scandal and other high-profile political events that take place between 1960 anc 1966.

Following the pattern of story subjects in general, the percentages of political stories about subjects other than the political process are small, seldom constituting more than 15 percent of all political stories in any given time 
period and usually constituting less than 10 percent. Although there are some fluctuations in these sub-categories over time, no pattern of overall increase or decrease is evident.

The 1971 edition of $\mathrm{CBC}^{\prime} \mathrm{s}$ news directives stated that there should be a balance in the types of story subjects reported. It advised news producers "[to] counteract news of crime, accident and disaster, [by watching] for news of a more constructive sort -- developments in the areas of business, industry, economics, culture, education and so on."13 Concerned that television news in the 1960 s was concentrating on political stories, the CBC began to assign reporters specializing in such subject areas as labour and science. BY 1979, the CBC had six television reporters covering Parliament, five foreign correspondents, 10 reporters doing reports for both national and regional CBC newscasts and reporters specializing in news of science and medicine, business, labour and legal issues. However, these administrative changes and the awareness of the need for subject balance indicated by the news directives are not reflected in a substantial change in the content of the newscasts. It is surprising, too, that issues that seem to have increasingly become part of the public discourse, such

13. CBC News Style Book, (1971), 25. 
as the environment and social justice, do not appear to be reported more frequently over time.

Knowlton Nash, long time CBC reporter, administrator and anchor, has said that an attempt to parcel the news by different subjects, to ensure a strict ratio of political news to stories about health, for example, would be a distortion of journalism's function to reflect reality. ${ }^{14}$ John owen, managing editor of the CBC National News, similarly characterizes CBC's news philosophy of the late 19808:

You do the most important stories of the day and for the rest of the program it's got to be a balance of foreign, domestic, regional, national, human interest, specialist topics . . . after all, you have a number of talented people vying for 22 minutes of air time, trying to make a popular program. 1

John Fiske has written thac television news cannot reflect realicy because news workers try to make sure that the stories they select for each newscast represent various subject categories:

Categorization constructs a conceptuai grid within

14. National Archives of Canada/Moving Image and Sound Archives (hereafter NA/MISA). Carleton University Institute of Canadian studies collection, interview with knowlton Nash, 19 February 1988. All interviews cited in this thesis are from the same collection. Dates of interviews are given only in the initial citation, except in the case of two separate interviews of Nash, for which the dates are given in each citation to differentiate between them.

15. Interview with John Owen, 15 February 1988. 
which "raw" events can be instantly located and thus inserted into a familiar set of conceptual relationships. Categories are normalizing agents. They also serve as simple but effective structuring principles for the building of news programs. "Induetrial affalrs" or "foreign affairs" categories are used to group stories and to place them in the conventional sequence of the news flow. These groupings are part of the strategy by which news masks its social process of representation and presents itself 16 objective, as driven by events in "the real". 16

One explanation for the predominance of stories about the political process is that events such as elections and leadership conventions constitute a predictable supply of news. Of the stories about the political process, more than three-quarters are scheduled events for which broadcasters can plan coverage in advance.

A study by Robert Rutherford smith ${ }^{17}$ examined the degree to which television newscasts are a response to unplanned events and the extent to which broadcasters choose the news that goes on the air. His study of 20 American newscasts from 1978 found that 70 percent of the news stories were preplanned. This contradicts the simplistic notion that television news merely reflects a natural, unplanned reality. The characterization of spontaneous

16, John Fiske, Television Culture, (New York: Methuen, 1987), 287.

17. Robert Rutherford Smith, "Mythic Elements in Television News," Journal of Communication, 29 (No. 1, Winter 1979), 75-82. 
versus preplanned stories is significant as a measure of the degree to which the television news organization decides what is news or accepts decisions of newsworthiness made by others, such as interest groups holding news conferences. Smith modelled his analysis of preplanned news stories on the concept of the pseudo-event developed by Daniel Boorstin in his book The Image. According to Boorstin, the pseudo-event occurs because someone has planned it, mainly for the purpose of being reported. ${ }^{18}$ It would perhaps be too cynical to suggest that all preplanned events are planned largely for the purpose of being reported, but this is true of news conferences, tours arranged for the news media and other media events. A tour of Toronto's spadina Expressway held for members of the city council and the news media, and of refurbished apartments in the olympic village in Montreal are examples of stories in which the reporters make it clear that the events reported are media tours. Usually, however, the viewer is not told of the circumstances under which the reporter got the story. Hockey games, prize fights, the opening of the musical Hair, the annual awards ceremony for Canadian films and the

18. Daniel Boorstin, The Image, (New York: Atheneum, 1962), 11. Boorstin originated the term pseudo-event as part of a broader analysis of how society deceives itself by creating pseudo-events and believing them to be real. 
thirtieth anniversary gala of the National Ballet of Canada are certainly events that receive media coverage. But while they seek to attract the public, they are not planned solely for media coverage.

Floods and accidents are examples of spontaneous events. Examples of pre-planned events are news conferences and opening nights. Applying these categories to CBC television news stories presents a problem because it is not always possible to determine from the text of the newscast itself whether the CBC obtained the story from a controlled situation such as a news conference. This study has coded as preplanned such events as news conferences, public announcements and speeches, news originating from regular sittings of legislatures, coverage of election campaigns and results, political leadership conventions and conferences. The events taking place at the conferences are often spontaneous, but the act of covering the event is preplanned. For this reason, such events as the 1961 Commonwealth Conference and the 1960 Paris Summit are coded as preplanned.

spontaneous events include events impossible to predict such as fires, floods and other accidents and disasters. stories about riots and wars are also coded as spontaneous, although the tendency for particular world trouble spots 
such as Lebanon to become fixtures on daily television news programs means that coverage of such continuing stories can seem to become routine and planned. The item is coded as preplanned if it indicates that the minister made the remarks in the House of commons or at a news conference. If technology is the key factor governing television news coverage of spontaneous stories, the statistics should show a dramatic increase in the number of spontaneous stories, in keeping with the development of faster film and video processing and transmission. However, the statistical results show that technology is not the key factor at work here (see Table 5).

\section{TABLE 5}

STORIES ABOUT SPONTANEOUSLY-OCCURRING EVENTS

\begin{tabular}{llcl}
\hline PERIOD/SAMPLE & $\begin{array}{l}\text { \% OF NUMBER } \\
\text { OF STORIES }\end{array}$ & $\begin{array}{l}\text { OF TOTAL } \\
\text { DURATION }\end{array}$ \\
\hline II & $1956-57$ & $53.1(17)$ & 55.7 \\
& $1960-66$ & $41.7(122)$ & 32.1 \\
III & $1969-70 \mathrm{a}$ & $59.3(165)$ & 52.4 \\
& $1969-70 \mathrm{~b}$ & $56.2(36)$ & 49.0 \\
& $1974-79$ & $48.3(43)$ & 51.9 \\
\multirow{2}{*}{ IV } & $1980-88$ & $50.0(103)$ & 45.8 \\
& $1988 \mathrm{C}$ & $54.2(19)$ & 37.2 \\
\hline
\end{tabular}

The percentage of spontaneous stories does not increase as technology improves. Spontaneous news stories tend to decrease somewhat, instead of showing a dramatic increase 
over time. They show a considerable decline during the second provisional period, between the time of the 1956 and 1957 newscasts and the 1960 to 1966 newscasts. ${ }^{19}$

The development of extensive worldwide distribution systems via satellite, electronic news gathering and increasingly-portable equipment, which might be expected to free television news from having to resort to the coverage of pseudo-events, does not in fact have that effect. When television lacked the technology to capture fast-breaking stories on film, as in the 1950s, the medium was more at the mercy of politicians and other people who might have wanted the news to transmit their message. Leslie Jackson, who worked for CBC's television news service in Vancouver in the 19508, recalls that most events covered in the 1950 s and early 1960 s were orchestrated in that the camera equipment was not sufficiently portable to permit on-the-spot news coverage without elaborate set-up. Most stories were

19. The results of this study differ from Smith's findings. smith determined that 70 percent of the stories, all broadcast in 1978, were preplanned. Preplanned stories account for little more than 40 percent of the CBC newscasts for the 1974 to 1978 period as well as the 1980 to 1988 period. The percentage is approximately 10 percent lower for the other time periods, apart from 1960 to 1966, at 54.8 percent. Difjerences in the study time $p_{0}=2=1$, programs and coding definitions may account for the difference but it may also be that CBC's news reporting ability may have lessened its dependence on preplanned news stories. 
structured around interviews in the interviewee's office. 20

The percentage increase in the newscasts sampled between 1960 and 1966 Iikely is because of the Increase in the coverage of political events, such as elections, parliamentary debates, and announcements of government policies. These are coded as preplanned, even though some of the events turn out to be unexpectedly dramatic. Most of the preplanned stories in the sample are political, reflecting the general trend of political stories to increase over time.

Investigative or feature stories that do not focus on an apparently spontaneous event or a stage-managed event such as a news conference do not occur frequently in the sample. In the late 1970s, however, "The National" began an occasional feature called the special Report, consisting of longer in-depth stories, of approximately four to six minutes in length, and not necessarily closely tied to an issue in the news. Examples are a January 11, 1982 report on efforts by Canadian police to stop the illegal drug trade, and a February 26, 1987 report on how viruses cause dementia. Such stories often have no obvious news hook. They are apparently broadcast because a reporter or producer decides that they provide information of interest and 
signiflcance. In that respect, the stories are preplanned by the newe organization itself, but tisey are coded as epontaneous because they do not fit the definition of a pseudo-event.

Journalist Anthony Westell has pointed out another reason why preplanned news stories predominate. There are more institutions and organizations trying to manage the news by the use of pseudo-events and a corresponding willingness on the part of the news media to report those events. He has written, "The press gets really angry only when there is not enough managed news -- as for example, when the Prime Minister declines to hold a news conference. ${ }^{21}$

The 1970 s and 19808 have seen the development of many organizations that have come to view the news media and television in particular as media to be used to advantage rather than to be feared and mistrusted. It is difficult to determine the extent to which the organizers of a political rally or a street demonstration want to be covered by television news cameras. Environmental groups such as Greenpeace, however, rely on media coverage to help them

21. Anthony Westell, "Reporting the Nation's Business," in ed. G. Stuart Adam, Journalism. Communication and the Iaw, (Scarborough, Ontario: Prentice-Hall of Canada Limited, 1976), 65 . 
publicize their work. The decrease in spontaneous events on the news can to some extent be attributed to this growing ability of interest groups and politicians to present their message in a way suited to television. This seeking out of television coverage sometimes fails to get the desired effect.

For example, in a December 17, 1969 item about a bus tour by city councillors of a Toronto expressway, "Weekday" reporter J.J. Richards clearly is annoyed at having wasted his time covering what amounts to a non-story. He signs off by telling viewers, "Nothing new was added or suggested and Information revealed today has been public knowledge for many years." A report on "The National" of August 12, 1984 similarly reveals a reporter's frustration over the management of news. Covering the federal election campaign of Progressive Conservative leader Brian Mulroney, Bill Casey gives viewers a clue as to why his report is confined to clips of the candidate making speeches, one of which ironically criticizes the secrecy of the Liberal Party and emphasizes the public's right to information. Casey reports that, "between events, reporters on the rampaign bus drafted a petition asking Mulroney to answer some of their questions at a one-hour news conference before next week's debate." 
SUIALARY OF RESULTS

Advances in technology have not been accompanied by the opening up of CBC television newscasts to a broader range of story subjects and spontaneous events. The coverage of politics predominates throughout the provisional periods, pointing to a definition of newsworthiness which occurs early in the history of CBC television news. Television's dependence on preplanned events as sources of news, a dependence that seems to increase slightly over time, also indicates that news workers exercise choice in the definition of news. Pseudo-events raise the question of the management of news by governments, institutions and individuals other than the news media, taking a measure of that choice out of the hands of news workers. 
CHAPTER 3: ACCESSING VOICES -- WHO GETS TO SPEAK ON THE NEWS?

The legitimacy of television news as a realistic discourse which communicates a range of society's points of view lies within the extent to which it reflects what John Fiske has called "the multivocality of the real".22 In a study of Canadian television network newscasts broadcast in 1980, Robert A. Hackett found that politicians and government officials speak more frequently on the news than do other groups in society, such as representatives of organized labour, business and other non-government officials, and particularly, ordinary citizens. This is significant, Hackett argued, because the people who get to speak on the news are instrumental in setting the agenda for the public discussion of issues. ${ }^{23}$

This study looks at the frequency and type of interview clips over time, to determine if Hackett's findings are characteristic of Canadian television throughout its history. This study codes all instances of people talking, apart from anchors and reporters and narrators who are reporting the news. speech by anchors and reporters is

22. Fiske, 요. citt., 295.

23. Robert Hackett, "The Depiction of Labour and Business on National Television News," Canadian Journal of Communication, 10 (No. 1, Winter 1983), 5-50. 
coded separately. For the sake of simplicity, this category is called the interview category, but it also includes extracts of speeches, statements made during news conferences, and other actuality sound, such as that of a crowd of protesters shouting at one another. The measurement of the extent to which people other than reporters and news anchors get to speak on the news is significant because television news gives people an opportunity to be seen and heard expressing their own views.

Opinions and statements by different segments of society can also be represented on television news, albeit filtered through the wording of the newscast script, by means of attribution. Attribution is a measure of the degree to which television news acknowledges sources and uses such acknowledgement to present the news impartially. This study examines attribution and interviews in order to determine if there is a difference between categories of speakers merely attributed or given the greater access afforded by interview clips.

The interview category measures the extent to which politicians, government officials, and representatives of non-government organizations such as labour unions, interest groups, and professional associations, speak on CBC television newscasts. The study codes speakers who are not politicians or officials representing government or non- 
government organizations as to whether they are: central figures in a story; experts asked to comment in a story; ordinary citizens asked for their opinions; witnesses to an event; or people who are depicted as typifying a particular segment of society, such as single mothers or senior citizens, and hence serving as archetypes. CBC reporters and reporters from other media organizations are also coded as interviewees when they are interviewed as sources of information in a news story. The vox pop category, reserved for ordinary citizens not representing a particular organization, includes person-on-the street interviews. It also includes comments by factory workers questioned about the effectiveness of wage and price controls, a motorist stranded by a snowstorm, and people protesting a nuclear bomb test. Central figures may be ordinary citizens, but they are also participants in the news story; whereas ordinary citizens coded in the vox pop category are not. Examples of speakers coded as central figures are the relatives of crime victims, the parents of quadruplets, and a film-maker commenting on his winning an award. This category excludes speakers who are politicians or officials. On the basis of improvements in the technology of television news gathering, it might be hypothesized that the percentage of newscasts devoted to clips of people speaking would increase over time. The "Tabloid" and "Newsmagazine" 
programs for the first provistonal period, between 1952 and 1954, are noteworthy because they seldom use interview clips. An 83-second clip of statements by several United Nations officials about a prisoner-of-war exchange constitutes the only interview segment in the "Tabloid" programs. ${ }^{24}$ The development of reliable sound-on-film technology in the second provisional period of 1956 to 1966 should presumably lead to an increase in the number of interviews. Improvements in the portability of recording equipment potentially facilitates the use of more interviews of people from different categories, giving more access to union leaders, for example, or ordinary citizens. Efforts that began at the CBC in the 1960 s to develop reporters specialized in covering news other than politics, might also be expected to result in more interviews and attribution of persons other than politicians.

Interview clips constitute close to one-quarter of the total duration of news stories in this study, showing a general but slight tendency to increase over time (see Table 6).

24. When there are several clips of various government officials in a single story, they are coded as one interview. Interview clips within a single story are coded separately only when the interviewees are in different coding categories. 
TABLE 6

USE OF INTERVIEW CLIPS

\begin{tabular}{|c|c|c|c|}
\hline \multicolumn{2}{|c|}{ PERIOD/SAMPLE } & \multirow[t]{2}{*}{ OF TOTAL } & \multirow{2}{*}{$\begin{array}{l}\text { DURATION OF STORIES } \\
\begin{array}{l}16.3 \\
16.8\end{array}\end{array}$} \\
\hline II & $\begin{array}{l}1956-57 \\
1960-66\end{array}$ & & \\
\hline III & $\begin{array}{l}1969-70 a \\
1969-70 b \\
1974-79\end{array}$ & & $\begin{array}{l}30.1 \\
19.4 \\
23.1\end{array}$ \\
\hline IV & $\begin{array}{l}1980-88 \\
1988 \mathrm{C}\end{array}$ & & $\begin{array}{l}21.6 \\
31.6\end{array}$ \\
\hline
\end{tabular}

$a=$ "Weekday" and "Weekend".

$b=$ "CBC Television News" and "The National".

$c=$ "CBC News Saturday Report" and "CBC News Sunday Report".

The reasons for the increase during the "Weekday" and

"Weekend" programs are not clear. The higher figure during the "CBC News Saturday Report" and "CBC News Sunday Report" in 1988 can be explained by the inclusion of a discussion between the anchor and two reporters on the sunday program.

The increase in the percentage of newscast time devoted to interview clips implies that there is a greater opportunity for representatives of different groups in society to speak on the news, but politicians and officials dominate throughout the provisional time periocs (see Table 7). 
TABLE 7

TYPES OF INTERVIEWS IN NEWSCASTS, 1956-1988

\begin{tabular}{|c|c|c|c|}
\hline $\begin{array}{l}\text { TYPE OF } \\
\text { INTERVIEW }\end{array}$ & $\begin{array}{l}\text { \& OF NUMBER } \\
\text { OF STORIES }\end{array}$ & $\begin{array}{l}\text { * OF TOTAL } \\
\text { DURATION }\end{array}$ & $\begin{array}{l}\text { OF ALL } \\
\text { INTERVIEWS }\end{array}$ \\
\hline $\begin{array}{l}\text { Canadian } \\
\text { Politicians }\end{array}$ & $10.4(104)$ & 7.6 & 33.6 \\
\hline $\begin{array}{l}\text { Other } \\
\text { officials }\end{array}$ & $7.6(76)$ & 3.6 & 15.8 \\
\hline $\begin{array}{l}\text { Non-Canadian } \\
\text { Politicians }\end{array}$ & $4.0(40)$ & 2.9 & 13.1 \\
\hline $\begin{array}{l}\text { Central } \\
\text { Figures }\end{array}$ & 3.1 (31) & 2.1 & 9.4 \\
\hline Experts & $2.0 \quad(20)$ & 1.5 & 6.8 \\
\hline $\begin{array}{l}\text { Government } \\
\text { officials }\end{array}$ & $2.9(29)$ & 1.2 & 5.3 \\
\hline Archetypes & $2.6(26)$ & 1.2 & 5.3 \\
\hline Vox Pop & $3.1(31)$ & 1.1 & 5.0 \\
\hline $\begin{array}{l}\text { CBC } \\
\text { Reporters }\end{array}$ & 0.30 (3) & 0.51 & 2.8 \\
\hline $\begin{array}{l}\text { other } \\
\text { Reporters }\end{array}$ & $0.20 \quad(2)$ & 0.45 & 2.0 \\
\hline Witnesses & $0.60 \quad(6)$ & 0.27 & 1.2 \\
\hline
\end{tabular}

Canadian politicians constitute the largest group of speakers, at close to one-third of the duration of all interviews. Most are federal government politicians. Ontario provincial politicians constitute the next largest 
group, no doubt because of the inclusion of programs in the "Weekday" series, shown only in the Toronto area. Next are non-government officials and non-Canadian politicians. The number of stories using interviews of Canadian politicians increases over time, but there is no consistent change in the percentage of total duration and a slight decline as a percentage of all interviews (see Table 8).

TABLE 8

INTERVIEWS OF CANADIAN POLITICIANS

\begin{tabular}{clccc}
\hline PERIOD/SAMPLE & $\begin{array}{c}\text { \% OF NUMBER } \\
\text { OF STORIES }\end{array}$ & $\begin{array}{l}\text { \& OF TOTAL } \\
\text { DURATION }\end{array}$ & $\begin{array}{c}\text { \% OF ALL } \\
\text { INTERVIEWS }\end{array}$ \\
\hline II & $1956-57$ & $0.0(0)$ & 0.0 & 0.0 \\
& $1960-66$ & $4.4(13)$ & 7.7 & 45.8 \\
III & $1969-70 \mathrm{a}$ & $9.7(27)$ & 11.0 & 36.7 \\
& $1969-70 \mathrm{~b}$ & $3.1(2)$ & 3.1 & 16.1 \\
& $1974-79$ & $23.5(21)$ & 8.8 & 38.4 \\
IV & $1980-88$ & $17.4(36)$ & 6.2 & 28.8 \\
& $1988 \mathrm{C}$ & $14.2(5)$ & 4.7 & 15.1 \\
\hline
\end{tabular}

${ }_{1}^{1}$ Percentage of total story duration in each sample period. 'Percentage of all interviews in each sample period. Numbers in parentheses indicate the number of stories in each sample period.

Politicians from other countries speak on the news for less time than Canadian politicians. The amount of time 
devoted to clips of non-Canadian politicians decreases (see Table 9). 25

TABLE 9

INTERVIEWS OF NON-CANADIAN POLITICIANS

\begin{tabular}{llcccc}
\hline PERIOD/SAMPLE & $\begin{array}{l}\text { \% OF NUMBER } \\
\text { OF STORIES }\end{array}$ & $\begin{array}{l}\text { \& OF TOTAL } \\
\text { DURATION }\end{array}$ & $\begin{array}{l}\text { \& OF ALL } \\
\text { INTERVIEWS }\end{array}$ \\
\hline II & $1956-57$ & $3.1(1)$ & 11.2 & 68.5 \\
& $1960-66$ & $3.7(11)$ & 3.7 & 22.3 \\
III & $1969-70 \mathrm{a}$ & $2.8(8)$ & 1.9 & 6.5 \\
& $1969-70 \mathrm{~b}$ & $1.8(1)$ & 1.6 & 8.6 \\
& $1974-79$ & $5.6(5)$ & 4.5 & 19.6 \\
\multirow{2}{*}{ IV } & $1980-88$ & $4.8(10)$ & 2.0 & 9.5 \\
& $1988 \mathrm{C}$ & $11.4(4)$ & 2.9 & 9.2 \\
\hline
\end{tabular}

The number of stories using interview clips of government officials, both Canadian and foreign, increases over the course of the sample, but the clips do not occupy a significant amount of time. The number of stories using clips of government officials tends to increase by only several percentage points. The clips seldom constitute more than two percent of the total duration of the newscasts or five percent of the duration of all interviews. The change is somewhat greater in the case of clips of non-government officials, which increase by approximately 15 percent. When

25. It is not clear why the percentage of interviews of non-Canadian politicians increases in the 1974 to 1979 period, particularly given that the percentage of news stories about Canada is highest during the period. 
compared to the duration of clips of government officials, clips of non-government officials tend to occupy slightly more newscast time and at least double the amount of interview time.

of the coding categories that measure the access to news time afforded to non-official speakers, the percentages of interviews of witnesses, central figures, experts, archetypes and people on the street are too low to show much change.

While politicians and officials have an advantage over less powerful groups in society in getting on the news, it is questionable whether many of the clips are of sufficient length and are placed in sufficient context to constitute effective communication.

Seldom is the viewer given the opportunity to hear the questions to which an interviewee is responding, although the reporter often paraphrases the question or establishes the context of the interview during an accompanying commentary. This study measures the extent to which reporters and interviewees are heard during a scrum, a news conference, or an interview (see Table 10). The reporter or interviewee may be off-camera during portions of the interview. The duration includes the interviewee's replies as well as the questions. This is not a comparison of total 
interview clips to the time a reporter is shown interviewing, because the overall percentage of people speaking includes such situations as speeches, statements in the House of Commons, and announcements, as well as interviews. The majority of comments do, however, take place during interviews and news conferences.

TABLE 10

STORIES THAT INCLUDE REPORTERS QUESTIONING

INTERVIEWEES

\begin{tabular}{llcc}
\hline \multicolumn{2}{l}{ PERIOD/SAMPLE } & $\begin{array}{c}\text { \% OF NUMBER } \\
\text { OF STORIES }\end{array}$ & $\begin{array}{c}\text { \% OF TOTAL } \\
\text { DURATION }\end{array}$ \\
\hline II & $1956-57$ & $6.2(2)$ & 16.3 \\
& $1960-66$ & $5.4(16)$ & 9.8 \\
III & $1969-70 \mathrm{a}$ & $11.1(31)$ & 18.6 \\
& $1969-70 \mathrm{~b}$ & $4.6(3)$ & 5.8 \\
& $1974-79$ & $13.4(12)$ & 8.7 \\
\multirow{2}{*}{ IV } & $1980-88$ & $4.8(10)$ & 4.1 \\
& $1988 \mathrm{C}$ & $14.2(5)$ & 4.3 \\
\hline
\end{tabular}

Table 10 shows that the story segments which include reporters questioning interviewees tend to constitute less than 10 percent of total newscast duration during each sample period and decrease slightly over time. The higher figure for the 1956 to 1957 period probably can be explained by the relative difficulty with which television news got filmed interviews on the air at that time. It was more difficult to edi. interview questions and replies to the 
extent done nowadays and still get the story onto the air on time. The only cliss of people speaking in the sample of 19508 newscasts are interviews that include audio of the reporter asking questions. The reason for the higher figure for the "Weekend" and "Weekday" programs in 1969 and 1970 is not apparent, although interview clips constitute a higher percentage of newscast time during that sample period than in most others. The overall pattern of decrease suggests a downplaying of the role of the reporter in gathering news. This is in keeping with the tendency for actuality clips on television news to become more tightly edited over time, making for a faster-paced newscast but increasing the degree of editorial intervention and consequently, the mediation of news.

When the percentage of newscast time devoted to interviews (see Table 6) is compared to the duration of interviews that include questions by reporters (see Table 10). It is apparent that most talk on the news does not include the interviewer's questions. Communication in this sense is one-way, denying the viewer the opportunity to assess responses in relation to the questions. The inclusion of reporters' questions is not, however, always a reliable indication of the spontaneity of an interview. This is because of the practice of television reporters to 
repeat their questions after an interview has been conducted. This will not occur in an impromptu iltuation such as a scrum, when reporters shout questions at the interviewee, or a news conference. When an interview is conducted in a more controlled situation, such as a one-onone interview of a politician in an office, reporters may repeat their questions, to make editing easier, providing an editor with cutaway shots of the reporter, and to clean up any questions that are posed awkwardly or inaudibly. The practice does, however, raise the possibility that a question phrased in a slightly different manner changes the context of the interviewee's response.

This study does not attempt to measure the effectiveness of the interviewee's comments, but the duration of clips does provide some indication of the degree to which speakers have an opportunily on CBC television news to give their views in detail. over time, the duration of speech clips per interviewee category declines. The data do not track the length of Individual clips. For axample, if several Canadian politicians speak in a single news report, only the total length of all clips is coded. Nevertheless, the results indicate that the average duration of clips decreases over time. The average duration of clips of Canadian politicians per story is 46 seconds. The 
average is highest for the 1960 to 1966 period, at 95

seconds, dropping to less than 30 seconds during the 1980 to 1988 period. The other interview categories show similar trends. One person-in-the-street interview consists of several clips of no more than five seconds each, making the interviewees' opinions no more than quips. With tighter editing, clips of less than 10 seconds appear more frequently in the 1980 s than in earlier time periods. Between 1985 and 1988 , there are 18 clips of Canadian politicians, none longer than one minute in length, and six under 10 seconds. In the 1950 s and early 1960s, impromptu interviews were rare and interview clips tended to be longer than they are now. The film and sound recording equipment of the era was bulkier and required more set-up time. Film processing and editing also took more time, making it more difficult do complex edits within deadlines. Technology has made it easier to do interviews. It has also made it easier to apply more production values to those interviews, altering the way in which people are given the opportunity to speak on the news.

Attribution of information given in each story is coded as to whether there is general attribution such as "it is reported that", "there are indications that", "sources say" or "observers in Washington are saying". Attribution is also coded according to categcries that parallel the 
interview categories: Canadian and non-Canadian politicians; government officials; non-government officials; experts;

witnesses; central figures; archetypes and ordinary citizens. If a person is quoted and is heard being interviewed in the same story, only the interview is coded. 26

The tende--y for newscasts to acknowledge sources through the increased use of interview clips over time is reflected also in a decline in the number of stories that use neither interviews nor attribution. More than onequarter of the stories in the sample have no attribution or interviews (see Table 11).

TABLE 11

STORIES WITH NO ATTRIBUTION OR INTERVIEWS

\begin{tabular}{llll}
\hline PERIOD/SAMPLE & $\begin{array}{l}\text { \& OF NUMBER } \\
\text { OF STORIES }\end{array}$ & $\begin{array}{l}\text { \& OF TOTAL } \\
\text { DURATION }\end{array}$ \\
\hline \multirow{4}{*}{ II $\quad 1956-57$} & & $40.6(13)$ & 30.2 \\
& $1960-66$ & $31.1(91)$ & 21.9 \\
\multirow{4}{*}{ III $\quad 1969-70 \mathrm{a}$} & $26.9(75)$ & 11.5 \\
& $1969-70 \mathrm{~b}$ & $26.5(17)$ & 13.3 \\
& $1974-79$ & $19.1(17)$ & 6.2 \\
\multirow{3}{*}{ IV } & $1980-88$ & $15.0(31)$ & 4.1 \\
& $1988 \mathrm{c}$ & $25.7(9)$ & 8.7 \\
\hline
\end{tabular}

26. If one story contains more than one attribution of the same sub-category, such as several government officials, only one such attribution is coded for the story. 
In the "Tabloid" series, broadcast at a time when CBC television did not consider itself to be in the news gathering business, close to one-half of the stories have no attribution, representing close to 50 percent of the duration of the newscasts.

The percentage of stories which use neither attribution nor interview clips decreases steadily over the course of the sample. of these seemingly unauthored stories, more than three-quarters are basic reports that report the who, what, when and where of the story, physjcally verifiable events that are not subject to a variety of interpretations. The remainder are stories that place the viewer in the position of eyewitness to an event, attesting to basic details without providing analysis. Because the stories are straightforward accounts of events, it is less important for the viewer to know the source of the information than it is in the case of stories expressing opinions. Excluding source identification from such stories, nonetheless, leaves open the possibility that the viewer will think that the information originates with the network or the anchor. Over time, the percentage of stories that do not indicate sources declines, in keeping with the CBC's development as a gatherer of the stories it reports. Information is not often credited to news organizations, such as other 
broadcasters or the print media, but there appears to be a slight trend toward more on-air acknowledgement of these sources in the 1970 s and 1980 s. The marked decrease in the percentage of stories with no attribution, nevertheless, shows that $C B C$ television news increasingly has come to consider it important to tell its viewers the sources of its information.

The dominance of politicians and officials in the interview category is mirrored in the statistics in the attribution category. Similarly, the attribution of central figures, experts, archetypes, witnesses, reporters, and ordinary citizens accounts for comparatively insignificant percentages of the newscasts (see Table 12). None of the attribution categories show significant or consistent change over time, except for a decrease in the attribution of nonCanadian politicians. 
TABLE 12

TYPES OF ATTRIBUTION IN NEWSCASTS, 1956-1988

\begin{tabular}{ll}
\hline $\begin{array}{l}\text { TYPE OF } \\
\text { ATTRIBUTION }\end{array}$ & $\begin{array}{l}\text { OF TOTAL NUMBER } \\
\text { OF ATTRIBUTIONS }\end{array}$ \\
\hline General & $26.3(261)$ \\
Government officials & $22.0(218)$ \\
Other officials & $15.9(158)$ \\
Canadian Politicians & $14.1(140)$ \\
Non-Canadian Politicians & $9.5(95)$ \\
Central Figures & $3.7(37)$ \\
Media Organizations & $2.8(28)$ \\
Witnesses & $2.2(22)$ \\
Experts & $2.1(21)$ \\
Vox Pop & $0.60(6)$ \\
Archetypes & $0.40(4)$ \\
\hline
\end{tabular}

Numbers in parentheses indicate the number of attributions in each sample period.

Given the common view that politicians have become more aware since the early days of television news of the power of the medium, it is surprising that analysis of the newscasts does not reveal a considerable increase in the percentage of time politicians appear on television news.

Kenneth Brown, the first CBC television reporter assigned to cover events in ottawa, recalls that he once had 
to resort to trickery to get Prime Minister Louis st.

Laurent to make an on-camera comment. ${ }^{27}$ Brown and a

cameraman set up their equipment outside one of the doors of the Parliament Buildings, with the camera lights of to conceal their presence. As soon as the Prime Minister came out, the lights and camera now on, Brown began peppering him with questions about a conflict between Nationalist China and Communist China. Surprised and furious, st. Laurent felt that Brown's tactics had prompted him to say things he did not mean to say. Television coverage of politicians was more likely to take the form of rather stilted film of visiting dignitaries arriving at the ottawa airport, with the Prime Minister waiting to greet them and perhaps giving a short speech of welcome. Brown says that American politicians appeared frequently on canadian television newscasts, but Canadian politicians avoided television. Brown had to obtain special permission to bring a television camera into the centre Block of the House of Commons. Since Brown's tenure as a television reporter from 1954 to 1955 predated the 1959 admission of broadcast journalists to the Parliamentary Press Gallery, he faced further restrictions. Not only were broadcast reporters not allowed to sit in the reporters' gallery in the House of 
Commons, thus forced to find a spot in the public gallery. They were also not allowed to take notes while observing House proceedings. Larry MacDonald, who worked for CBC television in ottawa, recalls that during the controversial 1956 Pipeline Debate, he and fellow reporter Tom Earle could not get seats in the House of Commons galleries to cover the story. ${ }^{28}$

When broadcast reporters did gain admission to the Press Gallery they could take notes like print reporters, but were not permitted to bring their cameras and tape recorders into the Gallery. In order to give broadcasters an upportunity to record clips of politicians after the daily Question Period, an interview room was set up in the basement of the House of Commons. Kenneth Brown points out that within four or five years of his stint as a reporter, Canadian politicians were eager to be on television. close to one-half of the duration of all interview clips for the 1960 to 1966 period is of Canadian politicians.

There is a technological explanation for the absence of ordinary people on television news, particularly in the first decade of television. Reginald Jessup, who worked as a reporter and news director for CBC's television news service in Vancouver, starting in the 1950s, recalls that 
television news became more of a voice of ordinary people in the 19608 than in the $19508 .{ }^{29}$ Film with optical sound was more difficult to edit than the magnetic stripe film that came into use beginning in the late 1950s. This, compounded with the tendency for people to become very nervous during interviews, made it difficult to make interviews even of skilled speakers such as politicians into effective television news stories. CBS experimented with the recording of synchronized sound on film using a thin strip of magnetic tape affixed to the film in the camera. Before this, synchronized sound was recorded optically onto the film, meaning that the sound quality could only be monitored when the film was processed at a $l a b$ and not during the recording process. It was not possible to determine if there was adequate sound before the film was processed at a 1ab. Optical sound was of inferior quality to magnetic sound, subject to more hiss and distortion. When a newscast switched from the anchor in the studio to a film insert with magnetic stripe audio there was less contrast in the sound quality.

In the newscasts of the 1970 s and 1980s, there is a marked increase in production values that allow for more techniques to be used in a single story. There are more

29. Interview with Reginald Jessup, 6 June 1983. 
edits and an interweaving of reporter voiceover and actuality sound clips that make for a faster-paced item. News reports that consist almost entirely of the reporter interviewing someone, with few changes in camera angle, become rare. Such production values reduce the amount of time people other than the anchor or reporter get io speak on the news. This raises the possibility that a clip of a person serves more to document that a news source said something than to allow the person to communicate a message. The politician who has mastered the art of routinely delivering a witty 30-second quip or a member of a mediaconscious interest group who can deliver a trenchant comment in a few seconds might just have, however, as much or more impact on the viewer as an interview several minutes in length.

Unlike interviews, the decision to attribute a piece of information in a news story relies less on the technology needed to record the interview. It is easier for a television reporter to obtain an off-camera quote from an eyewitness to an accident than to film or videotape the eyewitness making the statement. The limited range of people quoted is an indication that news workers make judgements on who is newsworthy. 
The percentage of time allocated to talk by people other than reporters and anchors increases over time. CBC television newscasts have become multivocal, but only in the sense that there are more voices on the news, predominated by politicians and officials. It is clear from the statistical results that television news has not given greater access to more people representing different points of view, even though technological advances have made it easier to incorporate interviews in television newscasts.

The lack of access granted to ordinary citizens in the newscasts is to some extent explained by this elitistsounding passage in the 1971 CBC News Style Book:

It is difficult to report balanced opinion through man-in-the street interviews, Therefore, this reporting technique must be handled with care, especially when the subject is controversial. Experience has shown that a succession of uninformed opinions contributes little or nothing to the understanding of a serious subject. It can be effective and sometimes amusing to give this treatment to a light subject -- for instance, the length of skirts. 30

The tendency for clips to be short suggests that the effective communication of ideas is only part of the role of clips in the presentation of television news. Clips also

30. CBC News style Book, op. cit., 30. Person-on-thestreet interviews are not in fact common in this study, there being only three such interviews in the vox pop category. 
seem to serve to attest that someone has expressed an opinion to a reporter and to increase viewer interest by presenting speakers other than just the anchor or reporter.

As the newscasts move into the third and fourth provisional periods, the $1970 \mathrm{~s}$ and $1980 \mathrm{~s}$, there are more edits and an interweaving of reporter voiceover and actuality sound clips that make for faster-paced stories. News reports that consist almost entirely of the reporter interviewing someone, with few changes in camera angle, become rare. Such production values reduce the amount of time people other than the anchor or reporter get to speak on the news. The practice of television news to show an interviewee speaking while a reporter does voiceover narration indicates the importance television sometimes attaches to the visuals rather than the spoken message of the speaker.

SUMMARY OF RESULTS

This examination of the use of interview clips and attribution in $\mathrm{CBC}$ television newscasts indicates that television's increasing ability to record and transmit film and video of people speaking has not been matched by increased access to the airwaves by speakers representative of aifferent groups in society. The dominance of politicians and officials in the interview category is 
mirrored in the statistics in the attribution category. The use of interview clips tends to increase only slightly over time. Improvements in technology have enabled television news producers to assemble more clips and to edit them more quickly. But technology may actually detract from the messages communicated by interviewees. 
CHAPTER 4: FILY, VIDEO AND GRAPHICS -- SMORY-TELLING TOOLS OR ATTENTION-GETTERS?

One of the prevalent criticisms of television news is that news values are undermined by the need to present visuals, preferably sensational film of events as they occur. This chapter examines the visual content of CBC television newscasts over time in order to assess the extent to which film and graphics are used to make the news visual. ${ }^{31}$ Categories of film and graphics are intended to assess the narrative role of television news visuals and their potential to attract the attention of viewers, two functions that may conflict, in the opinion of critics of television news.

This study uses four classifications of film: talking heads, for film of people speaking whether they are heard or not; stock shots, for film that is marked file footage, library film, or is otherwise identifiable as film taken in the past: illustration, for film that is not of the actual event depicted, but cannot be identified as stock footage; and spontaneous footage. Spontaneous footage includes action footage showing events as they occur as well as

31. For the sake of simplicity, this study uses the term film to refer to both film and videotape. No attempt has been made to differentiate between filmed and videotaped inserts, since this distinction is difficult to make, especially by the audience. 
other, often mundane activities such as people attending meetings and dignitaries getting out $c$ f cars and arriving at airports. The use of spontaneous film is considered a measure of the extent to which television news exploits its visual potential. The degree to which television news uses talking head film, illustrative film and stock shots is interpreted as an indication that the footage is not necessarily or even frequently electrifying.

Graphics are another means by which television news tries to bring a visual dimension to the reporting of news. They can be relatively simple visual aids, such as still photographs of people or maps. They can be more complex, consisting of symbols or combinations of photographs, symbols and other artwork, potentially giving the news stories they accompany latent meaning.

This study codes graphics in the following categcries: still photographs of people; maps; photographs or drawings of things such as buildings and objects; action scenes such as still photographs of rioters or a hockey goalie making a save; and symbols such as corporate logos and flags. Graphics that are primarily composed of words or numbers, such as a dollar sign and the daily rate of the Canadian dollar, are coded as alpha-numeric. The composite category takes into account that some graphics, particularly those 
used in the late 1970 s and 1980s, consist of combinations of various elements: maps; symbols; numbers; words; and pictures of people and things.

CBC newscasts have become increasingly visual. The percentage of stories using no $f: 1 \mathrm{~m}$, video or graphics declines, with the greatest amount of change during the third provisional period, between the 1969 to 1970 period and the 1974 to 1979 period (see Table 13).

TABLE 13

STORIES WITH NO GRAPHICS, FILM OR VIDEO

\begin{tabular}{llcc}
\hline PERIOD/SAMPLE & $\begin{array}{l}\text { \& OF NUMBER } \\
\text { OF STORIES }\end{array}$ & $\begin{array}{l}\text { \& OF TOTAL } \\
\text { DURATION }\end{array}$ \\
\hline \multirow{2}{*}{ II } & $1956-57$ & $40.6(13)$ & 22.2 \\
& $1960-66$ & $29.4(86)$ & 14.0 \\
III & $1969-70 \mathrm{a}$ & $33.4(93)$ & 12.4 \\
& $1969-70 \mathrm{~b}$ & $31.2(20)$ & 11.4 \\
& $1974-79$ & $1.1(1)$ & 0.38 \\
IV & $1980-88$ & $2.9(6)$ & 0.66 \\
& $1988 \mathrm{C}$ & $5.7(2)$ & 1.6 \\
\hline
\end{tabular}

Numbers in parenthesis indicate the number of stories per time period.

Tables 14 and 15 distinguish between the use of moving image and fixed image visuals, confirming that the pattern of increase illustrated in Table 14 is shared by both types of visuals. 
TABLE 14

STORIES WITH NO GRAPHICS

\begin{tabular}{llll}
\hline \multicolumn{2}{l}{ PERIOD/SAMPLE } & $\begin{array}{l}\text { \& OF NUMBER } \\
\text { OF STORIES }\end{array}$ & $\begin{array}{l}\text { \% OF TOTAL } \\
\text { DURATION }\end{array}$ \\
\hline II & $1956-57$ & $62.5(20)$ & 54.4 \\
& $1960-66$ & $60.9(178)$ & 63.2 \\
III & $1969-70 \mathrm{a}$ & $67.6(188)$ & 72.8 \\
& $1969-70 \mathrm{~b}$ & $62.5(40)$ & 71.4 \\
& $1974-79$ & $12.3(11)$ & 12.7 \\
\multirow{2}{*}{ IV } & $1980-88$ & $16.9(9)$ & 5.3 \\
& $1988 \mathrm{C}$ & $10.4(16)$ & 7.0 \\
\hline
\end{tabular}

Both the use of graphics and the use of film and video increase. This suggests that television news graphics do not only serve as substitutes for hard-to-get film.

TABLE 15

USE OF FILM OR VIDEO

\begin{tabular}{llll}
\hline PERIOD/SAMPLE & $\begin{array}{l}\text { \% OF NUMBER } \\
\text { OF STORIES }\end{array}$ & $\begin{array}{l}\text { \& OF TOTAL } \\
\text { DURATION }\end{array}$ \\
\hline II & $1956-57$ & $31.2(10)$ & 41.7 \\
& $1960-66$ & $41.0(120)$ & 53.0 \\
III & $1969-70 \mathrm{a}$ & $42.4(118)$ & 62.0 \\
& $1969-70 \mathrm{~b}$ & $35.9(23)$ & 60.8 \\
& $1974-79$ & $65.1(58)$ & 73.5 \\
IV & $1980-88$ & $66.9(138)$ & 78.5 \\
& $1988 \mathrm{C}$ & $89.0(28)$ & 80.4 \\
\hline
\end{tabular}

The significance of television visuals lies not only in the amount used, but also in their type. News film and 
video can serve to depict the actual events reported, attesting to the veracity of the news report. They can also consist largely of a reporter or an interviewse talking about an event, distancing the viewer somewhat from the actual event. Even further from television's self-styled definition as a window on the world are stock shots from television news archives and other illustrative footage that do not show present-day events as they occur.

This study codes as talking head film any footage that shows a person speaking, whether the person is heard speaking or not. The definition includes reporters giving on-camera reports, apart from the few reports coming from the same studio as the newscast and presented live during the newscast. The film and video coded as spontaneous is defined as depicting events as they occur, ranging from routine events such as the arrivals of dignitaries at airports to the dramatic depiction of disasters and violence. The illustration category is used to measure the use of film that does not show a news event as it occurs. Examples of illustrative film in the sample are scenes of federal public servants coming out of office buildings at. lunchtime during a story on wage demands, oil refinery tanks and smokestacks in a story on industrial pollution, and cattle stockyards in a report on a federal subsidy for 
cattle producers. The use of animated graphics, text and stills during a film story presented by a reporter, posed a coding difficulty, as they are similar to the fixed-image graphics shown alongeide an anchor in the studio. It was decided to code any still photographs and other graphic elements appearing within a film story as illustrative film. Also coded as illustration are clips from other television productions such as an extract from a television interview by David Frost of former United States President Richard Nixon.

The results of this analysis indicate that television's reputation for favouring news stories that have sensational film is undeserved, at least in the case of the CBC. Overall, film of talking heads represents close to one-third of the total duration of the news stories and more than onehalf of the duration of all film used. Spontaneous footage accounts for less than one-quarter of the total duration, and 35.5 percent of the total film duration. Film coded as illustration makes up a comparatively small proportion, 6.4 percent of the total duration of the sample and 10 percent of the film. Stock shots constitute less than two percent of both the total newscast time and the total duration of film used. 
Most talking head footage consists of shots of politicians in news conferences, giving speeches and in other such controlled situations. scrums and other impromptu situations are rare. Throughout the time periods, talking head footage constitutes at least 30 percent of total newscast duration and between 40 and 50 percent of all film or video (see Table 16).

TABLE 16

STORIES USING FILM/VIDEO OF TALKING HEADS

\begin{tabular}{clcccc}
\hline PERIOD/SAMPLE & $\begin{array}{l}\text { \& OF NUMBER } \\
\text { OF STORIES }\end{array}$ & $\begin{array}{l}\text { \& OF TOTAL } \\
\text { DURATION }\end{array}$ & $\begin{array}{l}\text { \& OF ALL } \\
\text { FILM/VIDEO }\end{array}$ \\
\hline \multirow{2}{*}{ II } & $1956-57$ & $9.3(3)$ & 19.3 & 46.4 \\
& $1960-66$ & $19.8(58)$ & 31.7 & 59.9 \\
\multirow{2}{*}{ III } & $1969-70 \mathrm{a}$ & $29.4(82)$ & 37.0 & 59.6 \\
& $1969-70 \mathrm{~b}$ & $25.0(16)$ & 30.4 & 50.0 \\
& $1974-79$ & $46.0(41)$ & 33.3 & 45.2 \\
\multirow{2}{*}{ IV } & $1980-88$ & $53.3(110)$ & 36.0 & 43.8 \\
& $1988 \mathrm{C}$ & $57.1(20)$ & 44.2 & 54.9 \\
\hline
\end{tabular}

Percentage of total story duration per time period.

2Percentage of all film/video used per time period.

There is a small increase in the percentage of total newscast time devoted to spontaneous footage (see Table 17). When expressed as a percentage of all film or video, however, spontaneous footage fluctuates somewhat. It decreases by more than in percent during the 1956 to 1966 period. Table 16 shows that there is a greater use of talking head footage during the same time. By the third 
provisional period, 1969 to 1979 spontaneous footage tends to remain in the 30 percent range of all film and video. It increases for reasons that are unclear during the "CBC National News" in 1969 and "The National" in 1970.

TABLE 17

STORIES USING SPONTANEOUS FILM/VIDEO

\begin{tabular}{clcccc}
\hline \multicolumn{2}{l}{ PERIOD/SAMPLE } & $\begin{array}{l}\text { \& OF NUMBER } \\
\text { OF STORIES }\end{array}$ & $\begin{array}{l}\text { \% OF TOTAL } \\
\text { DURATION }\end{array}$ & $\begin{array}{l}\text { \& OF ALL } \\
\text { FILM/VIDEO }\end{array}$ \\
\hline II & $1956-57$ & $45.7(7)$ & 22.0 & 52.9 \\
& $1960-66$ & 25.0 & $(73)$ & 20.1 & 37.9 \\
III & $1969-70 \mathrm{a}$ & 24.1 & $(67)$ & 19.2 & 30.9 \\
& $1969-70 \mathrm{~b}$ & 25.0 & $(16)$ & 26.4 & 43.4 \\
& $1974-79$ & 44.9 & $(40)$ & 24.3 & 33.0 \\
IV & $1980-88$ & $53.3(110)$ & 27.8 & 29.7 \\
& $1988 \mathrm{C}$ & $65.7(23)$ & 31.3 & 38.9 \\
\hline
\end{tabular}

The increase in spontaneous footage in the "CBC News Saturday Report" and "CBC News sunday Report" is likely due to the role of the saturday program as a review of the week's news events and its consequent use of a number of video inserts of news events.

A 1978 CBC study found that only 10 percent of all of the film depicting events in its samule of newscasts broadcast in 1977 was of spontaneous events. 32 The results of the 1978 study and the present study differ because of Television News. (Ottawa: CBC, 1978), 56-57. 
differences in the sample and coding definitions, but both support the observation that television news film is not predominantly sensational or even spontaneous. Much of the film coded as spontaneous is not of unpredictable, breaking news stories, the coverage of which often depends more on the sheer luck of a cameraman being present than careful planning by the news organization. Spectacular or vivid footage is rare, even in the 1980 s.

The identification of stock footage requires scrutiny on the part of the viewer, who may not have the time, the knowledge, or the inclination to differentiate between stock footage and film more closely tied tc the time frame of the story. There are only 33 stories which appear to use stock shots, between 1969 and 1988. Of these, only 11 are clearly identified as stock shots, by a title on screen identifying them by date or as library or file footage. The highest percentage of stock shots appears in "The National" from 1980 to 1988 , in 23 stories.

The use of film coded as illustration shows a tendency to increase over time (see Table 18). The modest increase in the use of illustrative film comes during the third provisional period, 1969 to 1979, when film stories start to become more complex and production values more apparent. 
stock footage and illustrative film tend to be part of news reports that show other types of film, such as spontaneous footage or talking heads. Eight stcries broadcast between TABLE 18

STORIES USING ILLUSTRATIVE FILY/VIDEO

\begin{tabular}{clcccc}
\hline PERIOD/SAMPLE & $\begin{array}{c}\text { \& OF NUMBER } \\
\text { OF STORIES }\end{array}$ & $\begin{array}{l}\text { \& OF TOTAL } \\
\text { DURATION }\end{array}$ & $\begin{array}{l}\text { \& OF ALL } \\
\text { FILM/VIDEO }\end{array}$ \\
\hline \multirow{2}{*}{ II } & $1956-57$ & $3.1(1)$ & 0.24 & 0.59 \\
& $1960-66$ & $1.7(5)$ & 1.0 & 2.0 \\
III & $1969-70 \mathrm{a}$ & $9.3(26)$ & 5.1 & 8.2 \\
& $1969-70 \mathrm{~b}$ & $6.2(4)$ & 3.9 & 6.4 \\
& $1974-79$ & $21.3(19)$ & 13.6 & 18.5 \\
\multirow{3}{*}{ IV } & $1980-88$ & $27.6(57)$ & 11.3 & 12.1 \\
& $1988 \mathrm{C}$ & $20.0(7)$ & 3.1 & 3.8 \\
\hline
\end{tabular}

1983 and 1988 combine computer-generated images, photographs, and text printed on the screen into a form of presentation that has elements of the experimental tickertape television news formats in use in the United states in the early 1950s. Several stories use printed text of direct quotes from people testifying in parliamentary or court hearings, combined with the reporter's voiceover, still photographs, or actuality film. The text gives the words, in direct quotes, added authority and makes them easier to comprehend. One example is a February 26, 1987 story by David Halton on the report by the Tower Commission investigating a secret American government deal to exchange 
hostages in Lebanon in return for weapons sold to Iran. It uses footage of a news conference by the members of the commission as well as text of key points in the report. The text appears on screen against a background of a photograph of Ronald Reagan and a graphic of the White House. Adding to the visual complexity of the graphic is a small computergenerated graphic representing the Tower Commission in a top corner. The graphic is also used during the anchor's introduction to the story. It consists of a depiction of the pages of a report bearing a stars and stripes design, the cover of which has a label that reads "Ship to Iran," and the silhouettes of missiles. Such illustrative visuals tend to appear in stories for which film footage is difficult to obtain, such as legal proceedings from which cameras are barred, or reports on leaked documents.

This study codes photographs, artwork, and other fixed images as graphics when they appear alongside the anchor or accompany voiceover by the anchor or a narrator. Photographs of people and maps are the types of graphis used most frequently in CBC television newscasts (see Table 19). The tendency for newscasts to use more stills of people than other types of graphics reflects the frequency with which television news is about what individuals do and say, as opposed to long-term social trends or broader issues. Given 
the high percentage of stories about politics in the sample, it is not surprising that the majority of people pictured are politicians. However, the use of graphics of people and of maps declines over time.

TABLE 19

TYPES OF GRAPHICS IN NEWSCASTS, 1956-1988

\begin{tabular}{lr}
$\begin{array}{l}\text { TYPE OF } \\
\text { GRAPHIC }\end{array}$ & $\begin{array}{l}\text { \% OF TOTAL } \\
\text { OF GRAPHIC }\end{array}$ \\
\hline People & $37.2(237)$ \\
Maps & $19.9(127)$ \\
Objects and Buildings & $12.5(80)$ \\
Text and/or sumbers & $9.7(62)$ \\
Composite & $9.1(58)$ \\
Action Shots & $5.8(37)$ \\
Symbols & $5.5(35)$
\end{tabular}

Numbers in parentheses indicate the number of graphics.

Still photographs of people decrease from more than 50 percent of all graphics used in the 1960 to 1966 period to less than 25 percent in the 1980s. The use of maps also declines, from the 30 percent range in the 1950 s and 1960 s to less than 10 percent of "The National" from 1980 to 1988. Graphics of objects and buildings, text and numbers, and 
action shots are used less frequently than photographs and maps and show no pattern of change over time.

The most significant change in the use of graphics in CBC television news is found in the introduction of more complex graphics in the 1970s, when symbols and composite graphics start to appear. Most symbols in the sample are readily recognizable symbols widely in use, such as the logos of the CBC, CBS, Air Canada, Chrysler, and the Canadian Imperial Bank of Commerce. Flags of various nations and the coats of arms of several provinces are also coded as symbols. Symbols constitute 6.4 percent of the graphics shown in the newscasts between 1974 and 1979. In the 1980s, symbols represent between 10 and 12 percent of the graphics used. Most of the symbols require little interpretation by the viewer, as they are intended to embody commonly-held meanings. A few are more complex. One is a depiction of four arrows within a circle, all pointing to the centre. It is used in several stories about the federal government's Anti-Inflation Board. Another is a stylized blue flame inside two circles, illustrating a story aoout negotiations about the choice of a natural gas pipeline route.

The newscasts of the 1980s show a marked trend toward the use of complex graphics combining symbols, maps, text 
and pictures of people and objects. It is these composite graphics that have the most potential to embody a set of latent meanings. All but three of the 58 composite graphics in the sample appear in the fourth provisional period, 1980 to 1988. There are 47 graphics coded as composite in "The National" between 1980 to $1982,22.8$ percent of all graphics for the period. Composite graphics appear in eight stories on the "CBC News Saturday Report" and "CBC News Sunday Report", representing more than one-quarter of the total number of graphics.

The February 8, 1984 edition of "The National" is an example of the increasing visual complexity of $\mathrm{CBC}$ television news. "The National" illustrates its lead stories on fighting in Lebanon with four complex graphics. The first, accompanying a story on that day's shelling of Beirut by an American battleship, shows the silhouette of the guns of a battleship firing on a map of Lebanon. An American flag is in the background. The lead-in to a CBS reporter's item on the withdrawal by British, Italian and French peacekeeping forces from Beirut and the decision by American marines to remain in Beirut is a graphic that shows a map of Lebanon. To the left and right of the map are four silhouettes of soldiers' faces in profile, filled in with the designs of the flags of the four countries. The 
anchor's introduction to a story about various militia groups in Beirut shows large, crumbling letters spelling the word Beirut, in the red-and-white colours of the country's 1lag. The green cedar of Lebanon is also depicted. Other examples of composite graphics found in the sample are a cruise missile swooping around a maple leaf and the figure of a soldier made up of the letters in the words martial law and standing on the flag of Poland.

Improvements in technology help to explain why CBC television newscasts use more visuals over time. One of the challenges facing the news service in the first provisional period, 1952 to 1954 , was the development of a means to obtain film of both national and international events. In 1957, the CBC joined a news film exchange organization, the British Commonwealth International Newsfilm Agency Limited (BCINA). The CBC hoped BCINA footage would supplement the film it obtained from 149 freelance cameramen, including 25 outside Canada, as well as from United Press-Movietone (UPMT) and television networks in Britain, other European countries and the United states. The CBC strove to improve its sources of news on film and the technology to distribute television news across Canada. In November of 1954, the CBC began a project to exchange news film with three private television stations, CFPL in London, ontario, CFQC in 
Saskatoon, Saskatchewan, and CKCW in Moncton, New Brunswick. The CBC supplied the stations with approximately 10 minutes of news film dally, most of it originating with the CBC. In turn, the stations supplied the CBC with copies of nationally significant film stories they shot. ${ }^{33}$

By 1956, CBC newsrooms in Toronto and Montreal were exchanging same-day news film via a closcd-circuit microwave link, adding winnipeg to the closed-circuit network by 1957 . Microwave was an improvement over having to depend on airplanes to transport film. The microwave transmission system relayed signals from the broadcasting station to a costly network of microwave towers, to another broadcasting station, and from there to viewers' homes. The CBC's 19561957 annual report expressed pride in the capacity of the microwave network to get film cif news events onto the air quickly. For example, the CBC was able to send film of a fire in Montreal by air freight to Toronto, by microwave feed to winnipeg and from there to Vancouver by air, arriving in time for the $11 \mathrm{p.m}$. newscast. ${ }^{34}$ when the CBC completed its coast-to-coast microwave natwork in 1958, live

33. "News Co-op: A Perfect Answer," Canadian Television and Yotion Picture Review, 1 (No. 12, August-september 1955), 4.

34. CBC, Annual Report 1956-1957, 15. 

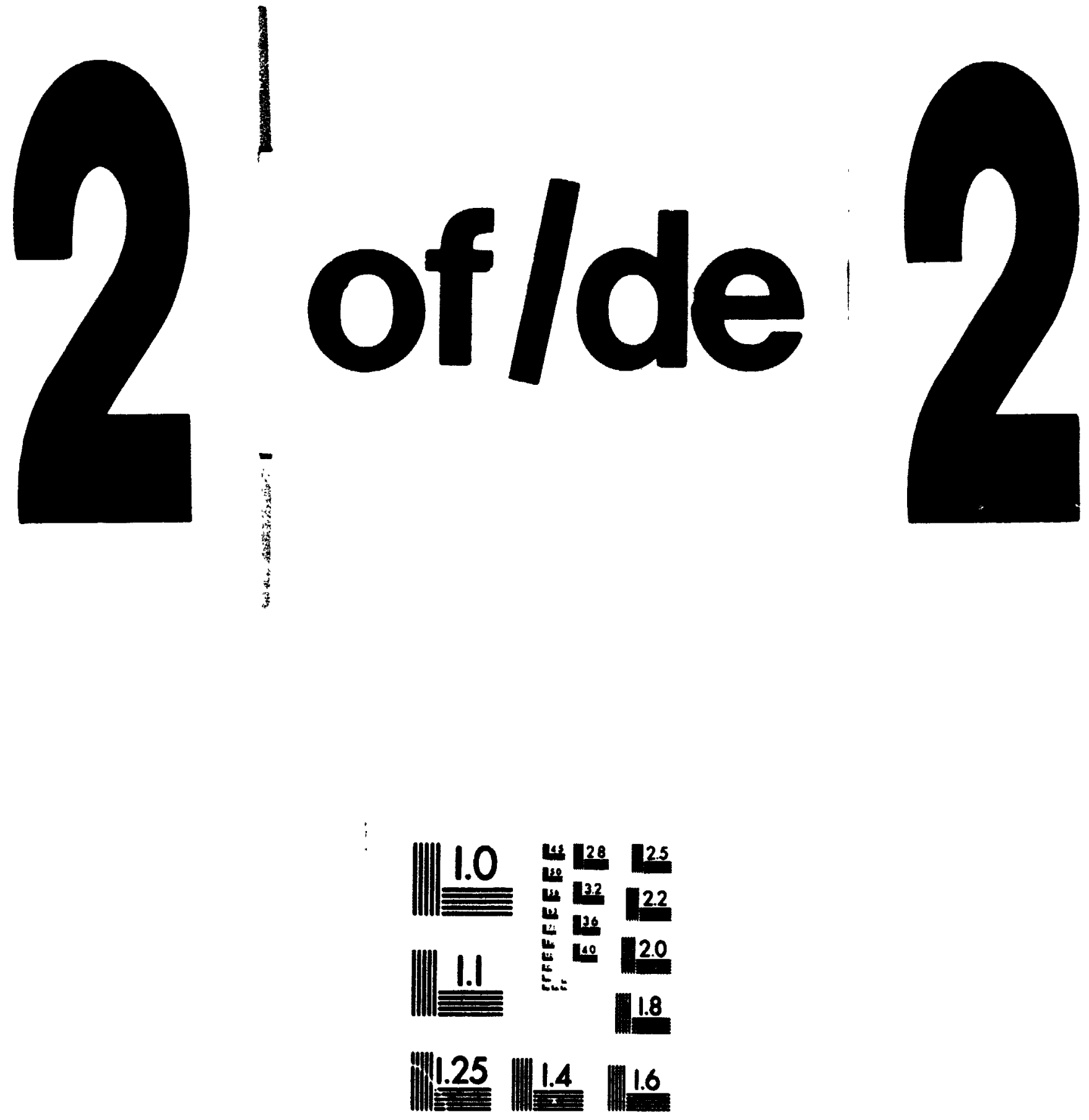

MICROCOPY RESOLUTION TEST CHART

NATIONAL GUREAU OF STANOARDS

STANOAAO AEFERENCE MATERIAL 1010

(ANSI and ISO TEST CHAAT No 2) 
television news was within reach of 80 percent of Canada's population.

The launch of the trans-Atlantic communications satellites Telstar in 1962 and Intelsat I in 1965 apparently did not revolutionize the way $C B C$ television news used film. Before Telstar went into operation, it took news stories at least 24 hours to get to Canada via overseas flights. Telstar did not prove to be of much use in television news, however, because it could only transmit between North America and Europe for little more than 10 minutes each hour. Intelsat I, nicknamed Early Bird, could transmit 24 hours a day, but booking time on it was too expensive for routine use. There are very few film clips in the sample from 1960 to 1966 which are identified as via satellite transmissions.

The CBC improved its ability to report the news visually with the 1972 launch of Anik, Canada's first domestic communications satellite. Anik made it easier to distribute timely news film and video to CBC television stations. Another factor that aided the use of visuals was the introduction of videotape technology. Videotape cut production time because it did not require laboratory processing. It reduced costs because footage shot but not used could be taped over. Videotape had been around since the mid-1950s, but it was not initially considered practical 
for news gathering, one reason being that it was harder to edit than film. By the 1970s, videotape had advanced to the point that it could compete with film, in the crispnisss of its images and the ease wich which it could be edited. There were video cameras and recorders that were lighter than film equipment and did not require as strong a light source as did film. In the late 1970s, the CBC tested the practicality of videotape by equipping its Parliamentary Bureau in Ottawa with electronic news gathering (ENG) cameras, recorders, and editing machires. By 1978, 16 CBC newsrooms across Canada were equipped for ENG. The timesaving capacity of videotape enabled the CBC to say in 1978 that it could get a report on the air in 30 minutes. ${ }^{35}$ "The National" switched its operation from film to videotape in 1982 .

Technological advances also contributed to the increase in the use of graphics of growing complexity, but the manner in which CBC television graphics were prepared underwent little substantial change until the 1980s. Frank stalley, the anchor of the 1956 and 1957 newscasts in this study sample, recalls that CBC's graphics were primitive when he read the "CBC Television News" in the mid-1950s. The title

35. The CBC -- A Perspective, (Ottawa: CBC, May 1978), 163. 
for the newscast consisted of lettering pasted onto a piece of corrugated cardboard. The news department wanted to get away from the static shot of a newsreader seated at a desk. In order to vary the visual presentation and to use more of the studio space, the CBC achieved the effect of a rear screen projection system by using a four by six-foot wooden frame. Grooves in the frame enabled two stagehands to slide in large blowups of still photographs and artwork mounted on cardboard. This was the only method the CBC then had to show the anchor and the graphics in the same shot. 36

In the late 1950s, the American networks began using a rear screen projector that had two light sources on one screen. Rear screen projectors project slides and film from behind a screen. This permits the addition of superimposed titles and other text over the on-air picture and a smoother switch from one graphic to another. The CBC also began using the system, known as cellomatic. Before the CBC switched to showing the in-studio portions of its newscast in colour in 1969, graphics had to be $f_{c}$ irly simple in order to be picked out by the black-and-white cameras. Television news graphics were prepared by hand for rear-screan projection as late as the 1980 .

36. NA/MISA, Moving Image and Sound Archives collection, Beyond the Printed word Symposiun: Then and Now: Presenting and Daliyering the News Report, October 20, 1988 . 
The computerized graphics systems that television news organizations began using during the $1980 \mathrm{~s}$ made the preparation of newscasts faster and more flexible. When the CBC began planning the move of "The National" to $10 \mathrm{p} . \mathrm{m} .$, the producers looked at ways to improve the look of the news. On a visit to the American networks, they saw stateof-the-art computer graphics capable of creating threedimensional shapes and more sophisticated movement of those shapes on the screen. Computer graphics systems enable artists using computer terminals and video monitors to select textures, colours, and styles that create fine lines or the effects of a paintbrush or pencil, using the computer system to store the finished design. Freeze frames can be incorporated into the graphic, from film, videotape, or a live transmission. The resulting electronically-created images are chromakeyed onto the screen. Such systems can also show slides.

The growth in the technological capacity to use film, video, and graphics does not in itself explain the increase in the use of visuals on CBC television newscasts. Fixed images, which might be considered a relatively inexpensive substitute for film and video, do not in fact play that role over time. As film and video use increases, so does the use of graphics. This seems to indicate that attitudes on the 
part of news workers are important factors in the visual presentation of television news. The type of fixed and moving images provides a clue to the purpose news workers and television critics think visuals have in the television newscast.

By the mid-1960s, media critics were finding the CBC's television news visually dull. Writing at a time when the daring and controversial current affairs series "This Hour Has Seven Days" was attracting considerable attention, Peter Gzowski expressed the opinion that CBC news prssentation lacked the inventiveness of the network's current affairs programs. Br the mid-1960s, the CBC had a string of critically-acclaimed current affairs programs, such as "Close Up" and "Inquiry", and the news department's weekly series "Newsmagazine" was more oriented to detailed coverage of breaking news than it had been in the 1950s. By comparison, the daily newscasts seemed lacking. Gzowski criticized the scarcity of actuality reports from reporters out in the field and interviews with people in the news:

Oh, sure there are occasional reports from outlying centres by someone standing peering into the camera, the wind blowing through his hair, and sometimes they even show us pictures of someone they 're been interviewing. But it's always -- 

-... :

always -- just the barebones of what we're going to read in the newspapers tomorrow anyway. ${ }^{3}$

GzowskI acknowledged that a particular strength of television news is its capacity to show film of events as they occur. There are more breaking stories than it is logistically or physically possible to cover, but CBC television news need hardly be restricted to a headline service. Toronto newspaper columnist Dennis Braithwaite wrote that reporters and news readers did too much talking on CBC television news, instead of presenting more visuals. Braithwaite even said that the verbal content itself was not interesting:

If there is an art of TV speaking. . . it has yet to pique the interest of CBC news-writers and announcers. They still follow the old radio ways - . and are usually producing for both media at once, since the audio part of the TV film is generally used for a radio broadcast as well. 30

Some CBC news producers shared the critics' judgement of the network's presentation style, prompting the CBC to revamp its newscast in 1966, adding more visuals and actuality sound.

The CBC was trying to get away from an over-dependence on talking head footage, which often lacks the story-telling

37. Peter Gzowski, "The Sheer Boredom of CBC's News," Kaclean's Magazine, (February 5, 1966), 43.

38. Dennis Braithwaite, "No Visual Vision," The Toronto Globe and Mail, February 2, 1966, 27. 
power of spontaneous footage. But some broadcasters and news workers have cautioned that it should not be discounted as a means of providing accurate, if dull, news reporting. Norman DePoe, whose career as a CBC television reporter spanned almost three decades, wrote in a 1977 article that an on-screen report by an expert reporter makes for better television journalism than does the insertion of film not closely linked to the story. Writing before television cameras were allowed in the House of Commons, television critic Blaik Kirby echoed DePoe's sentiments:

The demand for film is so intense that, on occasion, desperate producers have resorted to using film that is obviously not worthy, simply to get the story into the nightly National News at all. The policy brings out the essential difference between news and television as a means of delivering it. TV is visual, news often is not. The goings on in Parliament, for example, may be vitally important but are often almost impossible to illustrate. Instead, we get the solid, stolid reportage of Ron Collister. ${ }^{39}$

The 1961 CBC News Directives and Style Guide suggests that the CBC mistrusted visuals, fearing that their potential $\ddagger$ s entertain the viewer compromised their value as a journalistic tool:

While every legitimate effort should be made to make visual the news for TV audiences, CBC policy of regarding news as information and not entertainment must be recognized in both 
television and radio. Strict news values -significance, importance, public interest -- must be placed first if the handling of film or other graphic material.

Despite technological advances which have made it easier for television news to obtain film and videotape of events as they occur, CBC television news producers appear to have resisted the temptation to alter the newscast simply to accommodate attention-grabbing film. The tendency for spontaneous footage to constitute a smaller percentage of newscast time than talking head footage in each time period suggests that news producers screen sut much of the spontaneous film which has become more easily available over time. Still, anchor Peter Mansbridge describes the network's commitment to making the news visually interesting in the 1980s:

\footnotetext{
"The National" is a 22-minute broadcast. We like to try and have roughly 15 or 16 minutes of it actual film, tape, plctures of the events. After all, we are television. You don't want to just see a person sitting in a studio reading the news. You want to see it and that's what we've been offering.
}

The use of stock shots and illusirative film is to some extent a measure of the medium's inability to obtain

40. CBC News Directives and Style Guide, (March 1961), Section 1.5 .

41. Interview with Peter Mansbridge, 19 February 1988. 
actuality footage or an unwillingness to allow some stories to be told by a reporter or anchor on screen without visuals. In an article written to mark the twenty-fifth anniversary of television in Canada, Norman DePoe criticized what he considered the over-use of stock footage that was not closely or genuinely related to the story:

If a reporter mentioned wheat, the screen had to show one of those tired old NFB shots of a combine rolling majestically across a golden prairie. Every time the cost-of-living index comes out we get the same tired, tricked-out footage from a supermarket or a department store. 42

The small percentages of stock footage and illustrative film indicates that $C B C$ news producers have not used such footage simply to inject visual content into a news story. The increasing use of illustrative film in the $1970 \mathrm{~s}$ and 1980s, however modest, does indicate that CBC television news is showing a greater willingness to tackle stories that are complex and difficult to tell with pictures. 43

Graphics are also a means of providing viewers with visual information about news stories. The study results indicate that television news graphics are becoming more complex. In her study of television news coverage of the

42. Norman DePoe, "The Failure of TV News," In Search, 4 (No. 3, Summer 1977), 18.

43. The use of stock footage also depends on the existence of stock shot libraries and the ease with which suitable images can be located. 
1980 referendum campaign in Quebec, Gertrude Robinson analyzed the significance of graphic symbols such as the maple leaf and the fleur-de-1is to show how graphics distil points of view, acting, in effect, as "the concentrate of their user's imaginary universe. "14 Increasingly complex graphics on television news add another layer of symbolic content to the news, one that gives the viewer more visual information to interpret. Theorists such as Gertrude Robinson have argued that this is significant insofar as graphics can have latent ideological content, reflecting attitudes about society.

Some graphics are quite clever and elaborate. A graphic shown during the anchor's introduction to a story about a meeting of the Liberal Party's Ontario caucus depicts the Party's symbol of a large red letter I with a maple leaf. An extension of the letter curls around the western part of a map of canada. If this were accompanying a story on the Liberal Party's inability to win seats in Western Canada, the graphic could be seen as symbolizing this. Since the story focuses on ontario Liberals, the curling of the letter around the map seems to be simply an

44. Gertrude Joch Robinson, "Television News and the Claim to Facticity: Quebec's Referendum Coverage," in eds. Willard D. Rowland and Bruce Watkins, Interpreting Television: Current Research Perspectives, (Beverly Hills, California: Sage Publications, 1984), 211. 
artistic flourish. Another imaginative graphic accompanies a report on a Toronto butcher who refuses to use metric measurement in his shop. A meat cleaver cuts into beef in the shape of the logo of the federal Metric Commission, a large letter $\mathrm{H}$.

Together with computer-generated combinations of text, photographs, film and drawings that appear within stories presented by reporters, the detailed graphics that appear next to the anchor on the screen are indicators that CBC television news is trying to look as visually interesting as other television programs, particularly American network newscasts. Bill Morgan, director of CBC's office of journalistic policy and practice, says that the American networks use too many graphics, overemphasizing news as entertainment. Graphics should have a journalistic purpose rather than simply an aesthetic use. ${ }^{45}$

Knowlton Nash says that CBC television news has changed over time because increased use of visuals makes the newscasts seem faster-paced. In the past, newscasts typically showed reports that consisted solely of the talking head of the reporter, but now viewers see less of the face of the reporter and more visuals to illustrate the story. The purpose of the technology, in Nash's view, is to 
Improve television's ability to report news, particularly in the case cif such complex stories as the economy, which do not readily translate into visuals. He explains that the television graphic is "not there to make it (the newsj look prettier. It's not there to speed up things so much as it is there to make a complicated story comprehensible to an average audience. "166 SUMLYARY OF RESULTS

The use of graphics, film and videotape has increased on CBC television newscasts. Technological developments making it easier to use film, video, and graphics help to explain the ircrease in the use of visuals. It appears, however, that $C B C$ television news has not used attentiongrabbing, sensational footage to the extent made possible by technology, thus maintaining the importance of the information function of the news over entertainment values. Film of talking heads, which tends to be unsensational, accounts for more than one-half the duration of all film used. Spontaneous footage of news events as they occur accounts for less than one-quarter and it is seldom spectacular. Illustrative and stock footage constitute a very small percentage of the film and videotape. Only 
spontaneous and illustrative footage show a tendency to increase over time, but the increase is small.

Maps and photographs of people are the types of graphic used most frequently in CBC television newscasts, but their use decreases over time. More complex graphics start to appear in the 1970s, becoming common in the 19808 with the introduction of computer-generated graphics. Ihere is a risk that the attractiveness of intricate graphics might conflict with their journalistic purpose to render points of a story more easily understandable. 
CHAPTER 5: THE ROLES OF THE ANCHOR AND REPORTER

According to many theories of television news, the anchor is at the top of the hierarchy of voices in the television newscast -- a seemingly all-knowing controller of the news. The anchor's role is paramount because the reporters, film, graphlcs, and other devices are "amplifications of the basic account offered by the presenter and never contradict his account; their function is to legitimize his authority." ${ }^{67}$ Reporters located in the fisld, where the stories are occurring, serve as witnesses to the events and conclude each story. After a reporter signs off, the anchor usually moves on to the next story, rarely continuing with the same subject, except co provide newer information or, in the case of human interest stories, an occasional chuckle. Robert stam has described the tendency of television news anchors to deliver the news with little facial expression or gestures as "minimalist acting" in keeping with the aim of television news to appear neutral. ${ }^{48}$

This analysis hagins with an examination of the amount

47. Richard Collins, Television News, (London: British Film Institute, 1975), 33 .

48. Robert Stam, "Television News and its spectator," in ed. E. Ann Kaplan, Regarding Television: Critical Approaches An Anthology, (Los Angeles: University Publications of America/The American Film Institute, 1983), 28. 
of time devoted to the on-air reading of the news by the anchor and anchor voiceover. This is a rudimentary measure of the anchor's authoritative role in the television newscast. Almost never does CBC television present the news so that the anchor is explicitly depicted as its author. This is apt because the anchor's role has largely been confined to on-air presentation, but the anchor remains the one person seen the most on news broadcasts. There are only 12 stories in the sample that are not presented by anchors. They tend to be stories grouped in the newscast because of a common subject, presented by reporters and given a common introduction by the anchor. The percentage of time devoted to news presentation by the anchor has declined over time (see Table 20). 
TABLE 20

STORIES SHOWING ANCHORS ON SCREEN OR DOING VOICEOVER

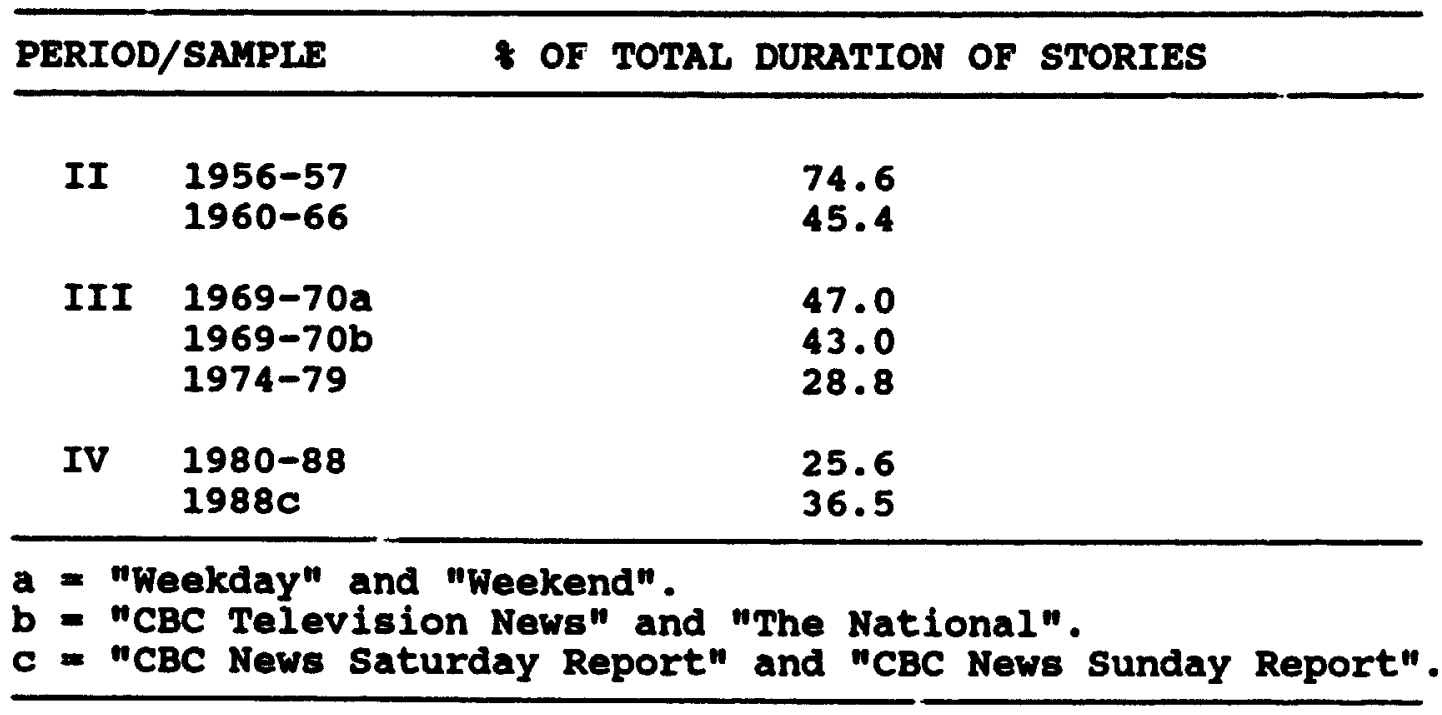

The extent to which the news anchor is the dominant oncamera news presenter in the early days of CBC television is also indicated in the "Tabloid" newscasts, which use the anchor on screen reading news stories or doing voiceover narration for approximately 90 percent of the time. There is a similar decrease in on-screen appearances by anchors (see Table 21). 
TABLE 21

STORIES WITH ANCHOR ON SCREEN FOR AT LEAST PART OF THE STORY

\begin{tabular}{|c|c|c|c|}
\hline \multicolumn{2}{|c|}{ PERIOD/SAMPLE } & $\begin{array}{l}\text { \& OF NUMBER } \\
\text { OF STORIES }\end{array}$ & \multirow{2}{*}{$\begin{array}{c}\text { \& OF TOTAL } \\
\text { DURATION } \\
\begin{array}{l}49.1 \\
44.4\end{array}\end{array}$} \\
\hline II & $\begin{array}{l}1956-57 \\
1960-66\end{array}$ & $\begin{aligned} 96.8 & (31) \\
100.0 & (292)\end{aligned}$ & \\
\hline III & $\begin{array}{l}1969-70 a \\
1969-70 b \\
1974-79\end{array}$ & $\begin{aligned} 96.7 & (269) \\
100.0 & (64) \\
97.7 & (87)\end{aligned}$ & $\begin{array}{l}36.0 \\
38.5 \\
25.7\end{array}$ \\
\hline IV & $\begin{array}{l}1980-88 \\
1988 \mathrm{C}\end{array}$ & $\begin{array}{ll}93.2 & (192) \\
77.1 & (27)\end{array}$ & $\begin{array}{l}21.2 \\
20.0\end{array}$ \\
\hline
\end{tabular}

The percentage of time devoted to voiceover by the anchor tends to be quite low and also decreases, particuiarly during the second provisional period (see Table 22).

TABLE 22

STORIES WITH VOICEOVER BY ANCHOR

\begin{tabular}{llrl}
\hline PERIOD/SAYPLE & $\begin{array}{l}\text { \% OF NUMBER } \\
\text { OF STORIES }\end{array}$ & $\begin{array}{l}\text { \& OF TOTAL } \\
\text { DURATION }\end{array}$ \\
\hline \multirow{3}{*}{ II $\quad 1956-57$} & $50.0(16)$ & 25.4 \\
& $1960-66$ & $2.7(8)$ & 0.9 \\
III & $1969-70 \mathrm{a}$ & $19.0(52)$ & 11.3 \\
& $1969-70 \mathrm{~b}$ & $10.9(7)$ & 4.4 \\
& $1974-79$ & $14.6(13)$ & 3.1 \\
\multirow{2}{*}{ IV } & $1980-88$ & $60.3(32)$ & 4.3 \\
& $1988 \mathrm{C}$ & $45.7(16)$ & 16.5 \\
\hline
\end{tabular}


During the 1960 to 1966 period, the CBC most often uses an unidentified CBC annourcer to do the volceover for reports introduced by the anchor, but not filed by reporters. There are 65 stories that use unidentified announcers to do voiceovers, all in the second provisional period. Two are in the 1956 and 1957 newscasts, representing less than 10 percent of the total duration. The remaining stories read by unidentified narrators are in the 1960 to 1966 peri.od, comprising approximately 20 percent of the duration of the newscasts. Most of the film narrated by the announcers is of foreign events from sources other than the CBC. Most of the stories are of disasters and human interest subjects, making the anonymity of the announcers not as important to the credibility of the newscasts. 49

One of the most noticeable characteristics of newscasts of the 19508 and 19608 is the degree to which news anchors are on screen for entire stories, seemingly justifying the complaint by critics that the newscasts provided no different content than radio news broadcasts. The percentage of time for which the anchor is seen for an

49. The reason for the increase in the percentage of anchor volceover in the "Weekend" and "Weekday" programs is not clear. The higher figure for the "CBC News Saturday Report" and "CBC News Sunday Report" probably is because the Saturday program regularly features a review of the past week's top stories, most with narration by the anchor. 
entire story drops sharply during the third provisional period, 1969 to 1979 (see Table 23).

TABLE 23

STORIES WITH ANCHOR ON SCREEN

FOR ENTIRE STORY

\begin{tabular}{llll}
\hline PERIOD/SAMPLE & $\begin{array}{l}\text { f OF NUMBER } \\
\text { OF STORIES }\end{array}$ & $\begin{array}{l}\text { f OF TOTAL } \\
\text { DURATION }\end{array}$ \\
\hline \multirow{3}{*}{ II } & $1956-57$ & & \\
& $1960-66$ & $40.6(13)$ & 21.9 \\
III & $1969-70 \mathrm{a}$ & $57.5(168)$ & 29.9 \\
& $1969-70 \mathrm{~b}$ & $56.1(156)$ & 21.9 \\
& $1974-79$ & $62.5(40)$ & 26.7 \\
\multirow{2}{*}{ IV } & $1980-88$ & $33.7(30)$ & 8.2 \\
& $1988 c$ & $29.6(61)$ & 6.8 \\
\hline
\end{tabular}

Two factors accounting for this are improvements in film technology and the development of a team of on-air reporters. For the "CBC Television News" broadcasts in 1956 and 1957, half the stories are script-only stories read by anchor Frank Stalley. On-screen appearances by the anchor drop dramatically by the 1974 to 1980 period, with additional, but small decreases thereafter.

The depiction of the anchor as a neutral deliverer of the news is characteristic of even the earliest CBC television newscasts. In the "Tabloid" newscasts from 1953, news announcer Gil Christie is serious and professional as 
he reacis the news, using little movement, gesture, facial expression or changes lil tone. There are no storles in the sample that feature the anchor in a locstion other than the studio. The need for the 1950 s anchor to remain within range of the boom microphone and the studio camera, neither of which were easy to move, also restricted the movements of the anchor.

There are few exceptions to the anchor's neutral mode of presentation, and only then at the end of light-hearted human interest stories that usually conclude the newscast. Rex Loring, anchor of the 6:45 p.m. "CBC Television News Evening Edition" of March 13, 1961, departs from the usual staid demeanour of the $C B C$ news anchor near the end of the newscast. The story is about a British officer whose regiment is being transferred to Malaya. The officer advertised for a Chinese woman to teach his men to speak Chinese and use chopsticks. He turned down the applican Hollywood actress Nancy Kwan, because he felt the attractive star would be too much of a distraction for the regiment. In keeping with the lighthearted nature of this human interest story, Loring turns and looks at the large still photograph behind him of kwan in a cheesecake pose, as he introduces the story. Loring's gesture makes $\mathrm{him}$ seem to share a moment of gentle humour with the viewer. 
On the "Weekday" programs, the end of the news portion of the program is signalled by banter between the two anchors and, often, the weather forecaster, Percy saltzman. On the December 17, 1969 "Weekday" program, co-anchor Rex Loring introduces the weather forecast by telling viewers, "If you're expectant about the weather, Percy's been doing your pacing for you for the last 20 minutes." Saltzman then pokes fun at the image of the news anchor with these comments to co-anchors Rex Loring and Earl Cameron:

I wasn't, you know, acting like an expectant father or anything. The only exerclse I get is walking up and down while you fellows rattle off the news. [Here the camera curs away to anchor Rex Loring laughing.] I'm constantly amazed with these two men, you know. The behind-the-scenes hassle that goes on. Rex Loring appears 30 seconds before he's due on air [here the camera cuts again to Loring laughing, while Cameron stands up and leaves the set] and they tie his mike on and neither of them really have seen the copy much in advance and they're really flying blind, and it's a tribute to their professionalism.

Saltzman's comments reflect the findings of this analysis that the role of the anchor in the presentation of television news has been most apparent in terms of air time. Although anchors are shown in almost every story, if only to provide a brief introduction, the amount of time they are shown or do volceover decreases over time. There is a corresponding increase in the amount of time reporters 
are seen or heard. Anchors appear on screen or do volceovers for a greater percentage of newscast time than all reporters, unt1l the 1974 to 1979 period, when reporters begin to predominate (see Table 24).

TABLE 24

STORIES SHOWING CBC REPORTERS ON SCREEN OR DOING VOICEOVER

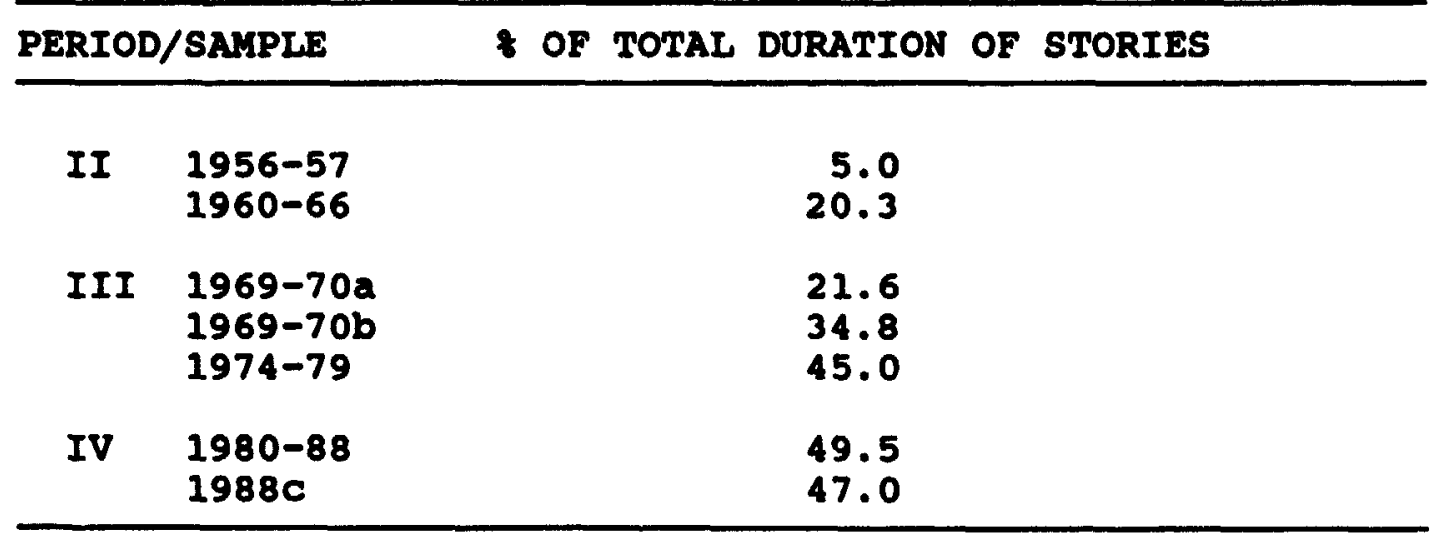

The results for the 1974 to 1979 period are comparable to those in a study of Canadian television newscasts from 1977. That analysis indicated that correspondents' reports account for almost one-half of airtime. ${ }^{50}$

Reporters appear in an increasing number of stories over time, but the percentage duration fluctuates (see Table 25). The lengthy interviews of $C B C$ reporters during the

50. Hapny Medium, on. cit., 40. 
TABLE 25

\begin{tabular}{|c|c|c|c|}
\hline & STORIES & SHOWING CBC REPORTERS & ON SCREEN \\
\hline \multicolumn{2}{|c|}{ PERIOD/SAHPLE } & $\begin{array}{l}\text { \& OF NUMBER } \\
\text { OF STORIES }\end{array}$ & $\begin{array}{l}\text { * OF TOTAL } \\
\text { DURATION }\end{array}$ \\
\hline II & $\begin{array}{l}1956-57 \\
1960-66\end{array}$ & $\begin{aligned} 3.1 & (1) \\
11.3 & (33)\end{aligned}$ & $\begin{array}{r}5.0 \\
15.8\end{array}$ \\
\hline III & $\begin{array}{l}1969-70 a \\
1969-70 b \\
1974-79\end{array}$ & $\begin{aligned} 7.5 & (21) \\
10.9 & (7) \\
29.2 & (26)\end{aligned}$ & $\begin{array}{r}7.9 \\
14.1 \\
9.6\end{array}$ \\
\hline IV & $\begin{array}{l}1980-88 \\
1988 C\end{array}$ & $\begin{array}{ll}32.5 & (67) \\
25.7 & (9)\end{array}$ & $\begin{array}{r}8.7 \\
23.3\end{array}$ \\
\hline
\end{tabular}

"CBC News Saturday Report" and "CBC News Sunday Report" account for the increase in 1988. There is a steady rise in the percentage cf reporter voiceover, accounting for the greater overall percentage of stories presented by reporters (see Table 26 ). 
TABLE 26

STORIES WITH VOICEOVER BY CBC REPORTERS

\begin{tabular}{llll}
\hline PERIOD/SAMPLE & $\begin{array}{l}\text { \& OF NUMBER } \\
\text { OF STORIES }\end{array}$ & $\begin{array}{l}\text { OF TOTAL } \\
\text { DURATION }\end{array}$ \\
\hline \multirow{4}{*}{ II $\quad 1956-57$} & $0.0(0)$ & 0.0 \\
& $1960-66$ & $4.7(14)$ & 4.5 \\
\multirow{4}{*}{ III $\quad 1969-70 a$} & $10.0(28)$ & 13.6 \\
& $1969-70 \mathrm{~b}$ & $17.1(11)$ & 20.7 \\
& $1974-79$ & $42.6(38)$ & 35.3 \\
\multirow{4}{*}{ IV } & $1980-88$ & $47.0(96)$ & 40.8 \\
& $1988 \mathrm{c}$ & $28.5(10)$ & 23.6 \\
\hline
\end{tabular}

There are no examples of reporters from other networks before the 1980s. Non-CBC reporters appear on screen or do voiceover for relatively small proportions of the total newscast duration, less than 12 percent in the 1980s. NonCBC reporters are on screen for only 2.8 percent of the duration of "The National" sample between 1980 and 1988 and 5.6 percent of the "CBC News saturday Report" and "CBC News Sunday Report". For the same time periods, they do voiceovers for approximately $\mathbf{s i x}$ percent of the total duration.

The absence of non-CBC reporters from the newscasts before the 19808 suggests that the CBC has only recently begun to acknowledge its use of non-CBC sturies. The small number of reports credited to non-CBC reporters in the 19808 
Implies that the CBC prefers to use its own reporters whenever possible.

The acknowledgement of non-CBC sources is significant, from a theoretical point of view, because it serves to demyetify the television news process. Peter Dahlgren has interpreted the way in which television news reveals or conceals the sources of its knowledge as a social relationship between the audience and television news, structuring the way a viewer perceives the news. In Dahlgren's analysis, television news does not provide enough indicators of the people and institutions from which television news organizations get the information they report:

- TV news reiterates the division between
producers and consumers of prolitical information.
The viewer is separated not only from the event
portrayed, but also from the history of how that
event became news-knowledge. Thus, the viewer can
never learn to be anything but a viewer of TV
news. The world is offered as a fragmented
inventory of events, which never permits the
viewer to formulate the rules of such knowledge
acquisition; these are monopolized by the news.

Dahlgren bases his interpretation on an analysis of the news anchor as in authoritative figure, the apparent source of much of the information on the news. By restricting the extent to which the viewer is told if the CBC or another culture, and society, 3 (No. 3, July 1981), 301. 
media organization is the originator of the story, television news simliarly structures the relationship between the nows and the viewer. It reduces the opportunity for the viewer to evaluate a television news story in the same way that an observant newspaper reader might evaluate a story on Washington politics bearing a Southam News byline differently from one with an Associated Press byline. This study also codes news stories according to the broadcasting organization apparently originating the story, to measure the extent to which television news makes clear the authorship of news stories. Stories that do not credit the CBC or other news organizations or are not presented by CBC reporters or reporters from other news organizations are coded as having no source indicated. At least one-half of the stories make no reference to a source, in the way that a newspaper story has a byline listing a reporter's name or the name of a wire service (see Table 27). 
TABLE 27

STORIES FOR WHICH NO SOURCE INDICATED

PERIOD/SAMPLE OF TOTAL NUMBER OF STORIES

\begin{tabular}{lll}
\hline & & \\
II $\quad 1956-57$ & 87.5 & $(28)$ \\
& $1960-66$ & $86.6(253)$ \\
III & $1969-70 a$ & $82.0(228)$ \\
$1969-701$ & $75.0(48)$ \\
& $1974-79$ & $51.6(46)$ \\
IV & $1980-88$ & $49.0(101)$ \\
& $1988 c$ & $65.7(23)$ \\
\hline
\end{tabular}

There are fewer such stories over time, the decrease coinciding with the increase in the number of stories presented by reporters. The rise in the percentage during the "CBC News Saturday Report" and "CBC News Suncay Report" can be explained by the format of the saturday program, which includes anchor volceover to video of a package of primarily international news stories of the past week.

The presentation of reports without crediting an originating news organization seems to be more a matter of style than any attempt to conceal sources, although for the viewer this omission may create the impression that all such stories originate with the CBC and furthermore, with the anchor. It would hardly be practical for the network to 
identify every story as a CBC story, particularly a brief script-only story read by the anchor.

Stories are coded as CBC stories through the use of

such phrases as "CBC News has learned", but more often

because a CBC reporter presents the story. In keeping with

the development of a network of CBC reporters, the number of stories for which the CBC is named as the source has increased steadily (see Table 28).

TABLE 28

STORIES IDENTIFIED IN NEWSCASTS AS CBC STORIES

PERIOD/SAMPLE $\quad$ OF TOTAL NUMBER OF STORIES

\begin{tabular}{lll} 
& & \\
II & $1956-57$ & 12.5 \\
& $1960-66$ & $13.3(39)$ \\
III & $1969-70 \mathrm{a}$ & $16.5(46)$ \\
& $1969-70 \mathrm{~b}$ & $21.8(14)$ \\
& $1974-79$ & $47.1(42)$ \\
IV & $1980-88$ & $46.6(96)$ \\
& $1988 \mathrm{c}$ & $31.4(11)$ \\
\hline
\end{tabular}

Given the CBC's aim to provide Canadians with international news as interpreted through Canadian eyes, the rebroadcast of stories originating from foreign television networks is significant. Analysis of scripts for 115 stories broadcast between 1963 and 1966 indicates that the CBC carried 23 stories with visuals from NBC, CBS, BCINA, 
and UPMT, but the sources are not identified during the programs. ${ }^{52}$ Non-CBC sources are seldom apparent to the viewer. Only 17 stories are identified during the entire sample as stories by other media organizations, primarily other television networks. There are seven stories from the 1969 to 1979 period and the remaining 10 from the 1980s. This indicates that the CBC now feels it more important to identify non-CBC stories than it did in the 1950 s and 19608. Political and military subjects are the most frequently treated in this manner.

It might prove stylistically awkward for broadcasters to identify the various sources of film during the newscast, given the requirement to compress a lot of information into a short period of time. John Owen maintains that the same standards should be applied to television news and the print media:

At the same time a newspaper doesn't tell you how much copy in a story is blended in from Reuters or Agence France-Presse or CP. You never know what the blended story is unless it's a byline. 53

52. It is not possible to code the originating news organizations for all stories in the sample because scripts and other production documents providing such information do not seem to exist for all time periods.

53. Interview with John owen. 
Nevertheless, Owen says that the CBC has become more conscious of the need to provide the viewer with more information on sources. He explains, "Whenever something is controversial or of questionable origin we certainly label it. We always label a report run by another network." In a study of viewers of British television news, Justin Lewis found that the audience did not identify anchors as the authors of stories, pointing out that broadcasters are not trying to pretend that they are the originators of all stories. Lewis stated, "Broadcasters do not expect, for example, the viewer to understand a news reader or reporter as the author of his/her statements, since he/she is, theoretically, a neutral communicator of "the news". 54

A CBC survey of viewers of "The National" in 1977 indicated that the personalities of the anchors are wellknown to the viewers. 55 A 1972 audience survey found, however, that viewers were not able to identify many CBC reporters by name. Only 25 percent of all people surveyed could identify names on a list as being CBC correspondents. In the case of regular viewers of "The National", the figure

54. Lewis, op. cit., 224.

55. The tate-Night Newscasts of the CBC, CTV and TVA Networks: Whe Watches Them and How are They Perceived?, (Ottawa: CBC, August 1977), 65. 
did not exceed 45 percent. ${ }^{56}$ The same survey found, however, that 80 percent of the respondents felt that the use of correspondents from the location of the news story makes the news seem more real. 57

The percentage of time during which a reporter is shown In a studio or a newsroom does not account for a large percentage of story time and it tends to decrease over time (see Table 29). Similarly, the CBC study of Canadian

TABLE 29

STORIES SHOWING CBC REPORTERS IN THE STUDIO

\begin{tabular}{|c|c|c|c|}
\hline \multicolumn{2}{|c|}{ PERIOD/SAMPLE } & $\begin{array}{l}\text { OF NUMAER } \\
\text { OF STORIES }\end{array}$ & \multirow{2}{*}{$\begin{array}{l}\text { OF TOTAL } \\
\text { DURATION } \\
\begin{array}{l}0.0 \\
8.5\end{array}\end{array}$} \\
\hline II & $\begin{array}{l}1956-57 \\
1960-66\end{array}$ & $\begin{array}{ll}0.0 & (0) \\
6.1 & (18)\end{array}$ & \\
\hline III & $\begin{array}{l}1969-70 a \\
1969-70 b \\
1974-79\end{array}$ & $\begin{array}{ll}2.5 & (7) \\
6.2 & (4) \\
7.8 & (7)\end{array}$ & $\begin{array}{r}4.0 \\
12.7 \\
2.9\end{array}$ \\
\hline IV & $\begin{array}{l}1980-88 \\
1988 C\end{array}$ & $\begin{array}{l}4.3(9) \\
8.5(3)\end{array}$ & $\begin{array}{r}1.8 \\
19.7\end{array}$ \\
\hline
\end{tabular}

56. Audience Attitudes and Reactions to the late Night National Newscasts on the CBC Fnglish TV Network and CTV Network, (Toronto: CBC, May 1972), 65.

57. Ibid. . 63. 
television newscasts broadcast in 1977 found that correspondents reading a story on-camera account for only eight percent of the total duration of the newscasts. 58

The percentage of reporters shown giving at least part of their reports from a news studio is higher during the sample of the "CBC National News" and "The National" in 1969 and 1970, apparently because of a number of reports filed from ottawa by parliamentary correspondent Ron collister and a story of more than five minutes in length presented from a newsroom during the time of the kidnapping of Quebec labour minister Pierre Laporte. The in-studio panel discussion on the "CBC News sunday Report" helps to explain the increase in the 1988 period.

The percentage of time during which CBC reporters are actually shown in the field does not change substantially over the time of the sample, but there is an increase in the number of stories using in-the-field reports (see Table 30 ). This study defines in-the-field reports as those which take place in a c.cation, often outdoors, other than a studio, a newsroom or a reporter's office. 
TABLE 30

STORIES SHOWING CBC REPORTERS IN THE FIELD

\begin{tabular}{|c|c|c|c|}
\hline \multicolumn{2}{|c|}{ PERIOD/SAMPLE } & $\begin{array}{l}\text { \& OF NUMBER } \\
\text { OF STORIES }\end{array}$ & $\begin{array}{l}\text { \& OF TOTAL } \\
\text { DURATION }\end{array}$ \\
\hline II & $\begin{array}{l}1956-57 \\
1960-66\end{array}$ & $\begin{array}{ll}3.1 & (1) \\
5.1 & (15)\end{array}$ & $\begin{array}{l}5.0 \\
7.2\end{array}$ \\
\hline III & $\begin{array}{l}1969-70 a \\
1969-70 b \\
1974-79\end{array}$ & $\begin{aligned} 5.0 & (14) \\
4.6 & (3) \\
21.3 & (19)\end{aligned}$ & $\begin{array}{l}3.8 \\
1.3 \\
6.6\end{array}$ \\
\hline IV & $\begin{array}{l}1980-88 \\
1988 \mathrm{C}\end{array}$ & $\begin{array}{l}28.1(58) \\
17.1 \text { (5) }\end{array}$ & $\begin{array}{l}6.8 \\
3.5\end{array}$ \\
\hline
\end{tabular}

In-the-field segments are usually only a small percentage of the total report. When a reporter is shown in the field, the sequence tends to be approximately 20 percent of the total story duration. studio reports, in comparison, account for more than 50 percent of the total duration of stories in which they appear.

Gaye Tuchman has written that the shot of the reporter doing a standup report in the field shows the viewer where the news is happening. This qualifies the reporter to talk about the event, without compromising his or her neutral stance:

In general, news film's adaptations of social roles stress neutrality. . Reporters filmed at the scene of 
a story aro clearly portrayed as being removed from, and uninvolved in, the action sequences. 59

Although the 1972 viewer survey found that on-location reports heightened the realism of television news, more than 16 percent of the stories in the present study with such reports show reporters in an unidentifiable location. Field segments, therefore, do not always aim to situate a reporter at the scene of the story, and may in some cases, only provide an uncluttered background visual, without any particular significance in telling the story.

Seldom does the in-the-field report show the reporter doing more than talking to the camera. The reporter may be at the scene of the news event, but is rarely shown as part of the event being reported. There are a few exceptions. During a 1978 report for "The National", reporter John Blackstone emphasizes the tragedy of pine forests dying of disease by snapping a brittle branch from a tree. On the March 8, 1970 edition of "Weekend", correspondent Michael Maclear stands outside Spandau Prison, the home of Nazi war criminal Rudolf Hess. Maclear puts himself into the story and sets the tone for his report with these words:

The absurdity of this place is as standing here before the cameras I'm likely quickly to become the only inmate of this prison. Photographs and journalists are strictly forbidden, although

59. Gaye Tuchman, Yaking News: A study in the Construction of Reality, (New York: Free Press, 197f), 116. 
there's nothing or no one currently at spandau to hide, except perhaps the embarrassment of the four great powers.

It is similarly rare for an anchor to interview a reporter during the newscast. There are only three interviews by anchors of CBC reporters, from 1987 and 1988. Sateliftes have made it easier to incorporate live interviews by the anchor during newscasts, a format little used before the 1980 s because of the dependence on direct land line connections. Knowlton Nash describes the CBC's attitude about such interviews, a change occasioned partly by improvements in technology:

[Essentially] the talkback, as it's called is there to elaborate on a point or two points that would have been made in his report itself. You could do it in the studio before, but couldn't have done it in the field without enormous expense and elaborate effort. ${ }^{60}$

In the 1980s, it is considered editorially acceptable and is technically practical to have the anchor interview a reporter during the newscast. The CBC's 1961 style guide provides another explanation for the infrequent use of anchor-reporter interviews during newscasts:

Negatively, the techniques that seem to invite expressions of personal opinion -- particularly reporters interviewing other reporters (except in a case where the reporter himseif is an undoubted and recognized authority, or has an eyewitness

60. Interview with Knowlton Nash, February 19, 1988. 
story to tell) -- should be avolded. ${ }^{61}$

The history of CBC television news has been

characterized by labour-management discussions and comment by media critics about the role of the news anchor. There has, however, been little change in the on-air role of the anchor.

The debate about the role of the anchor focused on the union-defined jurisdictional differences between the $\mathrm{CBC}$ news reporters and announcers. The dispute began early in the history of the television news service. In 1954, the CBC adopted the practice of having one announcer read the "CBC Television News". Larry Henderson became news anchor in that year, when Mavor Moore, then the program director for CBC television, concluded that the newscast would be more cohesive with a single anchor, rather than various ones. Moore felt that it was important to use an announcer who could combine a sufficiently neutral manner to maintain objectivity, while displaying an individuality that would be strong enough to hold the program together without distracting the viewers. ${ }^{62}$ Henderson encountered opposition

61. CBC News Directives and style Guide, op. cit., section 2.44 .

62. Christina McCall, "The Man Behind Canadian TV's Most Famous Face," Maclean's Magazine, (September 27, 1958), 60. 
when he wanted to file occasional film reports about international news events.

Among the changes made to the television news service in 1966 was the hiring of stanley Burke as the first news anchor with experience as a television reporter. The move was controversial. CBC stafe announcers felt only they had the proper training to read the news properly. Lamont Tilden, a CBC staff announcer, has bluntly expressed the animosity CBC announcers felt toward reporters who began doing on-camera reports during newscasts. He remembers that reporters were jealous of announcers who got on-air assignments reading the news. When reporters did standups, the announcers felt they did not present themselves on camera as well as CBC staff announcers did. ${ }^{63}$

viewers complained about the removal of popular anchor Earl Cameron, who had been reading the 11 p.m. national network news since 1959. Nevertheless, Burke's appointment was touted by Bill Cunningham, the executive producer of the news, because he felt a journalist would have more credibility as an anchor, being capable of doing more than just reading the news. Because of union squabbles, Burke did not get the opportunity to do his own stories on the 
newscast, but he did appear on CBC nows specials, along with other CBC reporters.

On "Weekend" Lloyd Robertson was permitted to participate in production meetings, prepare reports, and interviow guests in addition to reading the news, but interviews did not take place as part of the news portion of the program. None of the "Weekend" programs in the sample include a report credited to Robertson. Only once during a "Weekend" newscast in the sample does Robertson refer to his role as an interviewer. In an introduction to a December 21, 1969 report on the prescribing of drugs to drug addicts, Robertson mentions that he interviewed John Lennon on the previous evening's edition of "Weekend".

In December of 1976, the Canadian wire Services Guild announced that it was dropping its long-standing grievance against the use of CBC reporters as news anchors. But when Knowlton Nash, was appointed news anchor in 1978, the Canadian Union of Public Employees launched a grievance. The grievance, later dropped, stated that Nash's appointment violated staff agreements that the anchor had to be an announcer.

The appointment of CBC reporters Peter Kent, Knowlton Nash and Peter Mansbridge as anchors of "The National" demonstrated acceptance of the principle that the anchors 
should be capable of reporting as well as reading the news. Neverthelese, the newecasts indicate that the anchors rarely participate in the gathering of news. On "The National" of December 18, 1982, anchor Peter Mansbridge introduces a report by political correspondent David Halton of extracts of an interview of Prime Minister Pierre Trudeau, scheduled for broadcast the next day. The report shows Mansbridge and Halton interviewing Trudeau. By the late 19708, CBC publicity was referring to the anchor of "The National", Knowlton Nash, as CBC's chief correspondent, emphasizing his credentials as a reporter.

Knowlton Nash says that the contribution the anchor now makes to the newscast takes place mainly off-camera, in the form of copy editing and getting background information on storles from reporters, rather than preparing the presentation itself. He says, "I prefer to write very little and edit everything. It just gives a better imprint on the whole broadcast, rather than a footprint on a small part of it. 164

John Owen explains CBC's present-day definition of the on-camera role of trie anchor:

At the CBC I think the anchor is more active. The anchor still is somewhere in the middle between the very old-fashioned BBC reader tradition, which has also changed, and the different American

64. Interview with Knowlton Nash, 19 February 1988. 
superstar anchor, but in 1988, because television is the way it 1s, you must have an anchor who has the ablilty to break format, to conduct interviews on quite short notice, who has the ablilty to be advised that the story line is changing or storles are changing and basically be able to abanion the line-up of the program and go with the flow.65

The role of the CBC television reporter has changed much more than that of the anchor. The change can be attributed partly to technological developments that have made it easier to obtain and transmit stories by reporters. It also has come about as a result of a shift in the CBC's concept of itself as a news organization.

When television news was in its infancy, the CBC envisioned that cameramen, in the tradition of the theatrical newsreels, would be the principal recorciers of on-the-spot news. Writer-editors took the film and wrote a script for 1t, but did not at first accompany the cameramen to get the story and did not appear on screen. When Reginald Jessup switched from being a newspaper reporter to working for the CBC television news service in Vancouver in 1954, it was rare for CBC reporters to leave the newsroom in order to cover stories in the field. CBC television and radio atill depended on the news service of Canadian Press, rewriting it to suit broadcast style. Cameramen shot news

65. Interview with John Owen. 
Iilm that assignment editors asked them to shoot, providing notes on the names of people shown and other deta1ls of what they filmed. As with radio, actualities were rare in CBC television news reports. The outside broadcast department at the CBC was responsible for actuality programs. As film inserts came to be used more frequently in television newscasts, Jessup felt his job as a local assignment editor was becoming more complicated. He had to work with film aditors and with a team of freelance cameramen. The c)-meramen reported to the assignment editor and often knew more about how to use visuals to tell a story than did the reporters. 66

Kenneth Brown, the first CBC reporter appointed to work for CBC television in ottawa, recalls that in 1954 he was not permitted to do any on-camera reports. The CBC used freelancers to do reports, particularly about politics, a potentially-sensitive area for the government-owned network. Accompanied by a sound man and a cameraman, Brown mainly did interviews of politicians and covered routine stories such as the arrival of VIPs at the ottawa airport. Brown explains that it was too expensive to film an entire news conference. The CBC television news crew would ask the person giving the news conference to respond to some

66. Interview with Reginald Jessup. 
questions after the news conference. In the mid-1950s, he recalls that hand-held film cameras were only used for silent footage. 67 Filming an interview was an awkward process, requiring the interview subject to wait while the camera was set up on a tripod. This meant that politicians reluctant to face the television camera could easily evade the interview.

Primitive technology was not the only impediment to reporters in the 1950s. Jean Pouliot recalls that he wanted to gather the news rather than simply rewrite stories as reported by Canadian Press and other print sources. The first time this happened, the news had been on the air for only six months. Pouliot decided to record a telephone interview with a person who was in the news. He discussed the matter with his boss, Gunnar Rugheimer, who conferred with the head of CBC News, Dan McArthur. Rugheimer refused Pouliot permission, with the statement that the CBC was "not in the news gathering business." Pouliot remembers another incident, in which the Canadian Press reported that two people had been killed in a fire. The CBC had film showing three stretchers bearing the victims, but because CBC management considered Canadian Press to be the most accurate source, Pouliot was oblj.ged to report that two people were

67. Interview with Kenneth Ban. 
dead. 68 Knowlton Nash recalls that the CBC's team of foreign correspondents were gathering news instead of just reporting stories from sources such as Canadian Press long before domestic reporters did. ${ }^{69}$

There are few reporters seen or heard on the 1956 and 1957 newscasts in the sample. It miny, however, be misleading to conclude that there were few reporters on the air during the decade. During the 1950s, the CBC began to develop a team of reporters and to allow them to deliver their reports on camera. The CBC expanded its team of foreign correspondents, assigning reporters to London, the Far East and Paris.

Other CBC television news programs of the 1950 s provide evidence that the $C B C$ was indeed using reporters on air. The weekly news program "Newsmagazine" primarily used voiceover narration by CBC announcers until 1957, when most stories began to be presented by reporters. Individual film clips held at the CBC's National News Library also indicate that the $C B C$ was beginning to use more stories presented by reporters. Nevertheless, news frograms of the $1950 \mathrm{~s}$ used fewer reporters on-air than did programs of later years.

68. Interview with Jean Pouliot, 27 May 1983.

69. Interview with Knowlton Nash, 17 and 18 May 1983. 
One of the reasons why television news of the $1950 \mathrm{~s}$ was largely confined to film with voiceover narration and reporters seldom appeared on camera was that it was difficult to record and edit sound-on-film before magnetic stripe sound recording was developed in the late 1950s. In the 1950 s and 1960s, CBC television reporters also did reports for CBC radio, but most had started their journalism careers in the print media. This is likely one of the reasons for the higher profile of $\mathrm{CBC}$ reporters on television, starting in the late 1950s. Reporters accustomed to getting out of the newsroom and gathering their own stories would not be satisfied with the practice of CBC television news in the early 1950 s of relegating the reporter to the newsroom to rewrite wire copy and prepare stories from the visuals provided by cameramen.

Technology has contributed to the greater use of oncamera presentation by reporters. Reports from ottawa showing a reporter in a studio with a large photograph of the Parliament Buildings as a backdrop begin to be used frequently in the 1960 to 1966 period. Norman DePoe, Ken Mason and other CBC correspondents, sometimes did live feeds of news reports from ottawa to the national newscast in Toronto. They used a remote control studio in the Chateau Laurier hotel, near the Parliament Buildings. Studio 750, 
which went into operation in the early 1960s, gave the CBC the capacity to feed reports quickly to the network. Reporters could see how they would appear on screen by looking at a studio output monitor at the front of the room. They were also able to receive cues from the monitor or an incoming telephone line. SUMRYARY OF RESULTS

The anchor is shown in most news stories, if only to provide a brief introduction. The on-air role of the anchor has not changed very much, despite disputes between unions representing anchors and reporters. The percentage of time devoted to on-screen appearances or volceovers by anchors has decreased over time. This corresponds to an increase in the amount of time devoted to news presentation by reporters. The change can be attributed partly to technological developments that have made it easier to obtain and transmit stories by reporters. It also has come about as a result of a shift in the CBC's concept of itself as a news organization, which prompted it to begin sending reporters out into the field to gather news and to put them on the air to report their stories.

There appears to be a trend to identify the news organizations and reporters providing news reports. The number of stories that do not indicate a source decrease. 
The number of stories for which the CBC is named as the source has increased steadily.

Reporters are not often shown in a studio or a newsroom and this tends to decrease over time. The percentage of time during which CBC reporters are actually shown in the fleld does not change substantially over the time of the sample, but there is an increase in the number of stories using in-the-field reports.

Television news has remained a disparate set of bits of information linked by the anchor, but seldom featuring any on-air communication between the reporter and anchor or between reporters. Reporters are seldom shown doing more than talking to the camera. There are few interviews of anchors and reporters, even in the 1980s, when they have become more feasible from a technical standpoint. 
CHAPTER 6: THE NEWS STORY AS A GENRE -- FROM MIRROR TO MEDIATION

This thesis has examined presentation styles in terms of categories designed to measure the degree of mediation between the information that is the raw material for news and the final news product. Presentation elements mediate in the sense that they create an indirect Iink between reality and the depiction of reality on television news. This mediation can be intentional or unintentional, but there is nonetheless the risk that the means by which television news presents informatior can distort that information.

Analysis :f the way news has been presented on CBC television indicates that mediation has increased. CBC television news has changed from being predominated by basic chronicles of events to a form of journalism that increasingly tries to explain them. In a comparison of present-day television news and styles of political reporting in the American press of the nineteenth and early twentieth centuries, Michael schudson argued that the evolution of print styles mirrors changes in television news stories. ${ }^{70}$

70. Michael Schudson, "The Politics of Narrative Form: The Emergence of News Conventions in Print and Television," Daedalus, 3 (No. 4, Fall 1982), 97-112. 
Schudson identifled several conventions of present-day journalism that are not typical of the way newspapers depicted politics before this century. It is now conventional for news reports, whether in print or on radio or television, to summarize the main points of a event, placing the most important facts at the beginning rather than providing a chronological account. They also tend to depict a single event rather than continuous events. Speeches and documents are reported by means of highlights and quotation. Reporters covering an event place it in a context larger than the immediate time frame of the event.

There are parallels between Schudson's work and a study by Stephen Kline of British, American and Canadian television news. Kline's study serves as the analytical model used in the present study of CBC television news. Kline used a set of "genres of journalistic story telling"71 to measure the extent to which news in the three countries is free of bias. He defined four genres: the basic report; the you-are-there as eyewitness story; the story that attempts to balance views; and the inferential, analytical report. These are differentiated by the degree of mediation placed between the information and the viewer, the basic Comparison of National News Broadcasts," Canadian Journal of Communication, 7 (No. 4, March 1981), 54. 
report having the least amount of mediation and the inferential report the most.

This study does not use Kline's categories in exactly the same manner as he defined them. In particular, it does not restrict basic reports to short narratives of approximately 15 seconds in length. Basic reports are sometimes no more than brief headlines. They can be longer, but are restricted to the basic, physically verifiable facts of a story, with no analysis. Basic reports concentrate on chronicling the who, what, when and where of a story, instead of discussing the analytical why. The incidence of such basic reports on CBC newscasts shows a steady decrease (see Table 31). 
TABLE 31

BASIC REPORTS

\begin{tabular}{llll}
\hline PERIOD/SAMPLE & $\begin{array}{l}\text { \& OF NUMBER } \\
\text { OF STORIES }\end{array}$ & $\begin{array}{l}\text { \& OF TOTAL } \\
\text { DURATION }\end{array}$ \\
\hline \multirow{4}{*}{ II } & $1956-57$ & $75.0(24)$ & 63.6 \\
& $1960-66$ & $69.8(204)$ & 48.6 \\
III & $1969-70 a$ & $73.0(203)$ & 48.0 \\
& $1969-70 \mathrm{~b}$ & $68.7(44)$ & 44.6 \\
& $1974-79$ & $40.4(36)$ & 15.4 \\
\multirow{2}{*}{ IV } & $1980-88$ & $37.3(77)$ & 11.0 \\
& $1988 \mathrm{C}$ & $34.2(12)$ & 15.1 \\
\hline
\end{tabular}

$a=$ "Weekday" and "Weekend".

$b=$ "CBC Television News" and "The National".

$c$ = "CBC News Saturday Report" and "CBC News Sunday Report". Numbers in parenthesis refer to number of stories.

Basic reports decline sharply by the 1974 to 1979 period. At that time the television news service started to use more backgrounders and special reports. When basic reports are coded according to story subject, the pattern is similar to the overall percentage distribution of stories by subject in the sample. Political stories account for the majority of basic reports, followed by cxime stories, military stories, and human interest stories.

Kline characterized some stories by their "ability to generate a sense of the viewer-as-witness to the event by 
displaying or describing circumstances surrounding $1 t . n^{72}$ V1suals of events as they happen have been valued by the news media from the earliest days of the theatrical newsreels, when the novelty of brief scenes of a rushing locomotive or grainy lmages of Klondike gold-seekers pushing wheelbarrows of rock could enthral audiences despite few changes of scene or camera angle. At the very least, they seem to attest that an event has indeed occurred, even if the film is too fragmentary to tell the whole story. By definition, viewer-as-witness stories basically provide viewers with the kind of perspective they would have if they themselves were on the scene. There is no accompanying analysis or explanation of the significance of the event. The significance of this genre for Kline is that it embodies an ideal of television news -- the supposedly unmediated and spontaneous reflection of events as they occur. As he has explained:

Impartiality derives both from the sense of direct observation and the invisibility of the editorial control exerted in visuals production. It is... [this] format which most fluidly reflects the compatibility between the impartiality of objective observation and the immediacy of exciting news coverage.

72. Ibid., 57 .

73. Ibjd., 57 . 
The percentage of newscast time occupled by eyewitness reports remains fairly stakle over time, tending to constitute only 20 percent. This is surprising given improvements in microwave and satellite transmission systems that have provided a greater supply of film and videotape. The number of eyewitness stories in each time period shows lictle change until the late 1980s. The recent increase can to some extent be explained by the format of the "CBC News Saturday Report", which includes videotaped reports of news highlights of the previous week (see Table 32).

TABLE 32

EYEWITNESS REPORTS

\begin{tabular}{llll}
\hline PERIOD/SAMPLE & $\begin{array}{l}\text { \% OF NUMBER } \\
\text { OF STORIES }\end{array}$ & $\begin{array}{l}\text { OF TOTAL } \\
\text { DURATION }\end{array}$ \\
\hline \multirow{2}{*}{ II $\quad 1956-57$} & $15.6(5)$ & 20.4 \\
& $1960-66$ & $17.4(51)$ & 21.0 \\
\multirow{2}{*}{ III $\quad 1969-70 \mathrm{a}$} & $12.2(34)$ & 17.9 \\
& $1969-70 \mathrm{~b}$ & $14.0(9)$ & 21.8 \\
& $1974-79$ & $17.9(16)$ & 13.8 \\
\multirow{2}{*}{ IV $\quad 1980-88$} & $21.8(45)$ & 20.0 \\
& $1988 \mathrm{C}$ & $34.2(12)$ & 22.9 \\
\hline
\end{tabular}

When the eyewitness format is correlated with subject categories, disasters and accidents are the story subjects most frequently reported, at more than 35 percent. There is 
no apparent 1 ink between the eyewitnese format and other subject categories.

The eyewitness stories of the $1950 \mathrm{~s}$ and $1960 \mathrm{~s}$ are noteworthy for their detached character, because of the lack of actuality sound, the often poor quality of the visuals, and the absence of an on-site reporter. Anchors are the sole presenters of more than 40 percent of all eyewitness stories. Reporters are in approximately 30 percent, approximately the same number as presented by combinations of the anchor and an unseen narrator. This suggests that reporters are not important to this genre, but the analysis of story duration indicates that reporter-presented stories account for close to half of the total duration of eyewitness reports. Anchor-only stories and reports using both anchors and unseen narrators each account for approximately one-quarter of the total duration.

Eyewitness in-the-field sequences constitute another layer in the set of reality-effects in television news. The CBC reporter shown briefly aboard a helicopter as it flies over snowy fields adds credibility to the story, for example, because the viewer is given the information about a blizzard by soneone who is actually :... the scene. However, the reporter-as-eyewitness does not appear to be an important aspect of the eyewitness genre. Only 12 percent 
of the eyewitness stories show a reporter on location, constituting one-fifth of the total duration of such reporte. The depiction of the act of nowe gathering. which acts as a narrative device confirming the role of the reporter as an eyewitness, is 1 imited to an occasional cutaway shot of a reporter scribbling notes during an interview or of a camera trained on the speaker at a news conference.

The concept of the balanced news report poses analytical problems. Balance is not necessarily best measured by examining balance within stories, during the newscast as a whole, or a number of newscasts over a longer time period. It may not be accurately measured by the number of attributions in a story or sound clips. Kline did not define how his study used the concept of balance.

The CBC's news directives outline the network's interpretation of the concept of the balanced news story. The CBC News Directives and Style Guide for 1961 advised journalists that both sides of a story should be given, preferably within the same news story newscast. To give equal weight to the opposing points of view, the guide told reporters to use interview clips of representatives of the two sides, Instead of using a clip of one representative and citing the other in the script. The guide also stated that 
particular care should be taken to achieve balance in reports about domestic political controveray and labour disputes. ${ }^{76}$ In the introduction to the CBC's 1982 guidebook for reporters, Journalifetic Pollay, CBC president Al Johnson wrote, "[it] is obvious that fairness is not to be achleved by a rigid neutrality or mathematical balance. Otherwise, the lie could be made to appear true, the trivial could seem significant. 175

The difference between stories coded as balanced and stories coded as inference is that balanced stories quote or explain opposing sides of a problem or dispute. The inferential story often presents opposing sidee, but the story directs the viewer to a particular conclusion. Many of the balanced stories simply state opinions, without explanation. Stories coded as balanced represent less than 10 percent of the total story time, the lowest percentage of stories coded by genre. No trend is apparent in the percentages of balanced stories over time. Some balanced reports are no more than a simple statement of the positions of both sides and do not provide the viewer with enough information to weigh both sides of the argument. Of the

74. CBC News Directives and Style Guide, op. cit., Section 1.6.10.

75. Journalistic Policy, (Ottawa: CBC, July 1982), iii. 
stories coded as balanced, close to 40 percent are succinct statements of opposing views. Clips of people speaking, apart from reporters or anchors, account for 31.7 percent of the duration of balanced stories, but this does not necessarily mean that there are clips of people on opposing sides of an issue. There may only be a clip of a representative of one side of the story, while the reporter or anchor quotes a representative of the other. It is rare to see speakers on different sides of an issue speaking to each other, in a debate or dialogue, within the context of a newscast.

Most balanced stories are about subjects likely to be sensitive. Political stories account for 60.1 percent of all balanced stories, followed by 13.9 percent about military subjects, 6.3 percent on the subject of labour, and 5.1 percent about crime. There are no balanced stories about industry, science, sports, religion, education or the arts.

An example of a news story that presents different sides of an issue but does not give them equal time is a report by Craig Oliver on the March 15, 1970 edition of "Weekend". The story is about a small forest in Saskatchewan razed by the federal government to make 
farmland for a nearby Indian community. The ludicrous nature of the government's action is emphasized by anchor George Finstad's introduction:

Another case of man fighting to save his environment. This time it has pitted a whole community and provincial government officials against the federal government and a band of Indians. A federal department has wiped out a complete forest in one of the flattest, driest parts of the Saskatchewan dustbowl and conservationists are angered and concerned. Craig oliver reports.

This critical tone continues with opening shots of deer in a forest and oliver's introduction:

This, believe it or not, is southeastern saskatchewan. In the driest part of a dry province, this freak park is an oasis in a dustbowl. The tourist business it attracts is crucial to the economic life of nearby Carlisle, whose residents along with provincial politicians are dismayed at a move they fear may upset the ecological balance of the small parkland.

oliver uses clips of a provincial government politician and a conservationist criticizing the destruction of the forest, but gives the last word to the Indians. The report concludes with comments by the chief of the Indian band that the move will be financially beneficial to the Indians, who are quoted as saying that "as soon as they try to help themselves, everyone jumps on them."

The news story on the apparently wasteful and unjustified destruction of a fragile and rare forest is classified as an inference story, because it directs the viewer to a particular conclusion. John Hartley and Justin 
Lewis have considered this kind of news story as typical of television news, because its narrative structure favours one interpretation over another. Lewis has linked this to a convention of structuring news stories to tie up loose ends. News stories "are almost never presented as resolutions or developments or enigmas/questions". 76 This is not to say that television news reports do not acknowledge ambiguities, but the anchor's introduction to a report and the ways in which the reporter points out the significance of an event obscure the ambiguity that is part of the real world. This closing off of alternate interpretations is apparent in the way that Finstad's introduction sets the tone for the story about the Saskatchewan forest.

In his study of bias in television news, Kline used the term inference to describe news stories that go beyond the who, what, where and when of the basic report, the graphic descriptiveness of the eyewitness story and the presentation of opposing aspects of an issues. The inferential story has the greatest degree of mediation of the four genres identified by Kline.

Kline's concept of the inferential story is not entirely satisfactory because it tends to create a catch-all category for all news stories that have some analysis or

76. Lewis, 요. cit., 215. 
interpretation. The broad definition of the inferential category risks overemphasizing the degree to which bias is obviously present. The identification of the parts of a news story that incorporate inference is difficult because it requires the coding of subtle nuances in a reporter's tone or gesture. Sometimes inference is in the ironic juxtaposition of facts and images. This study interprets Kline's concept of the inferential news story as any news story in which there is speculation, however informed, about the outcome of a story and its implications or significance. Inferential stories, by their juxtaposition of various opinions, develop a logic that directs the viewer toward a particular interpretation of the story. The inferential category also includes stories that provide a context or background for issues in the news. It is important to note that stories are coded as inferential even if references to long-term implications, for example, only come in the reporter's closing statement. Inferential news stories increase almost steadily to more than 50 percent of the news stories between 1974 and 1988 (see Table 33). Such stories take up less than 10 percent of the newscasts in the $1950 \mathrm{~s}$ and at least 20 percent of the newscasts in the $1960 \mathrm{~s}$. 
TABLE 33

INFERENTIAL REPORTS

\begin{tabular}{|c|c|c|c|}
\hline \multicolumn{2}{|c|}{ PERIOD/SAMPLE } & $\begin{array}{l}\text { OF NUMBER } \\
\text { OF STORIES }\end{array}$ & \multirow{2}{*}{$\begin{array}{c}\text { \& OF TOTAL } \\
\text { DURATION } \\
\\
5.6 \\
21.1\end{array}$} \\
\hline II & $\begin{array}{l}1956-57 \\
1960-66\end{array}$ & $\begin{array}{ll}3.1 & (1) \\
7.1 & (21)\end{array}$ & \\
\hline III & $\begin{array}{l}1969-70 a \\
1969-70 b \\
1974-79\end{array}$ & $\begin{aligned} 8.2 & (23) \\
10.9 & (7) \\
35.9 & (32)\end{aligned}$ & $\begin{array}{l}22.9 \\
25.6 \\
64.6\end{array}$ \\
\hline IV & $\begin{array}{l}1980-88 \\
1988 c\end{array}$ & $\begin{array}{ll}31.5 & (65) \\
22.8 & (8)\end{array}$ & $\begin{array}{l}57.2 \\
53.7\end{array}$ \\
\hline
\end{tabular}

This study analyzes the inference stories as to the degree of interpretation they present. It subdivides the inferential category into: slanted reports that establish a strongly-worded point of view from the outset; stories in which the interpretations or analysis by reporters come only at the conclusion; backgrounders that give detailed information but little or no criticism; and reports that contain some analysis throughout, but leave room for various interpretations.

A story for the January 14, 1977 edition of "The National" is an example of a pointedly slanted inferential story. CBC reporter Jason Moscovitz shows how a reporter can point out issues and concerns to the viewer in a way that seems like editorializing, without any overt expression of personal feelings by the reporter. Moscovitz was part of 
a team of reporters invited to tour eight luxury apartments refurbished by the Quebec provincial jovernment in the residences constructed for the athletes competing in the 1976 Montreal Olympic Games. Moscovitz' critical tone is unistakable:

The good life, well, it's a matter of opinion. No one would dispute the apartments are small, especially the bedrooms. Indications are that if the Liberals stayed in power it would have cost a lot of money to be a viliage tenant.

Moscovitz is careful to use general attribution, such as in the words "it's a matter of opinion", "no one would dispute" and "indications are". He continues in what in the $1970 \mathrm{~s}$ and 1980s, especially, has become the television reporter's often crusading role to point out flaws in a government's policy or loopholes in a particular project:

The PQ [Parti Quebecois] government could quite legitimately ask who would pay $\$ 1000$ a month to live there. But that's not the only question. Another question: would it pay to remodel the other 892 apartment units? Question after question, problem after problem. While the olympic stadium is functional without its roof and tower, the olympic village is nothing until something is done.

Without making reference to anyone who might support the remodelling plan, Moscovitz concludes his report with a damning quote from an unnamed member of the committee set: up by the government to draw up plans for the olympic facilities. He says, "When pressed, one committee member 
suggested that perhaps the best thing to do would be to take out a multi-million dollar insurance policy and burn the place down."

The slanted news story is nonetheless rare. Its use does not increase markedly. Slanted stories, backgrounders and stories that are mainly descriptive until their conclusion each constitute less than 10 percent of inferential stories. Approximately 70 percent of the stories coded as inferential point out the significance or implications of an event, speculate on future developments, or provide background information in more depth than a basic report.

of the 160 inference stories, only three, all during the 1980s, are presented entirely by an anchor. This is in keeping with the 1978 CBC study, which found a marked difference between the type of information anchors present and that given by reporters. The anchor presents more facts. The reporter plays a greater role in interpreting the news. The CBC study found little expression by either the anchor or the reporter of "emotional favour or disfavour for people or things." 77 In the present analysis, 63.4 percent of inferential stories are about politics. No other single subject category accounts for more than seven percent

77. Happy Medium, op . cit., 82. 
of inferential stories and nine of the 15 subjects account for less than three percent.

The increase in the percentage of inferential news stories and the tendency for these stories to be presented by reporters indicates a change in the role of the television journalist. In his comparison of changing styles in the print media and television, schudson has written:

[The] journalist, no longer merely the relayer of documents and messages, has become the interpreter of the news. This new role allows the reporter to write about what he hears and sees, and what is unheard, unseen or intentionally omitted as well.70

Instead of being confined to the role of eyewitness, the reporter is permitted to refer authoritatively to aspects of a story that are not immediately apparent. One form this takes is that of the correspondent's assessment of what will likely happen at a meeting or other upcoming political event.

Analysis of the newscasts screened for this study indicate that some CBC reporters have been doing this kind of report since the $C B C$ began developing a team of foreign and domestic correspondents in the late 1950 s and early 1960s. Norman DePoe, the first staff reporter specializing in the reporting of federal politics as a member of the

78. Schudson, op. cit., 104. 
Parliamentary Press Gallery, characteristically filed reports that did more than simply tell viewers what had occurred in Parliament. In this March 15, 1961 report broadcast on the 11 p.m. edition of the "CBC Television News", DePoe points out the likely significance of the Progressive Conservative Party national convention:

In some respects this convention is a counterpart of the Liberal rally held in January, but observers here have noted one point where it will be different. This is the party in power. Much of its policy is made from day to day in cabinet meetings. It's not expected, then, that this convention will produce any resolutions widely at variance with that policy, although "the grass" are invited to voice their criticisms freely. The meeting does mark, though, as the Liberal rally did, a new trend in major party politics in this country, regular nationwide meetings to keep the leadership in touch with the rank-and-file.

The tone of the reporter is one of assurance and informed speculation rather than personal opinion. The story nonetheless marks the beginning of the role of the specialist reporter free to interpret the apparent significance of the news. The CBC's 1982 policy on broadcast journalism sanctions a broader role for its reporters:

In the interests of comprehensiveness, it is legitimate for reporters to place news events in a valid context. To this end, they may present an explanation of the background of the news based on careful research. They must not, however, express or reflect their personal opinion or bias. In other words, they must be able to abstract themselves from their personal views. The 
objective in providing explanation and analysis is to ensure that the audience, which relies on broadcast journalism as the primary source of information, is given as clear as possible an explanation of news events and issues and their

SUMALARY OF RESULTS

Changes in the conventional form of the news story over time seem to illustrate not only changes in societal attitudes toward politics, but also changes in the accepted role of the reporter. No longer is the reporter confined to presenting only the information that another on-the-scene observer would be able to observe. The style of inferential reports has not changed much since the CBC's first team of domestic and foreign correspondents began doing them. Inference has become more apparent in CBC television newscasts in that most reporters seem to inject some interpretation or analysis into their reports. The CBC's 1982 news policy indicates that the network not only permits reporters to do this but also expects it of them.

Basic reports that describe news events only in terms of the who, what, where and when predominated until the 1970s, when inferential reports became common. Despite the ability of television news film and video to situate the viewer as eyewitness in a way unsurpassed by radio and the 
print media, the eyewitness story has not been a dominant genre. Stories that do not attempt to do more than present a balance of opposing views similarly constitute only a small proportion of CBC television news stories. 
CONCLUSION: MAPPING PERIODS OF DEVELOPMENT IN THE PRESENTATION STYLE OF CBC TELEVISION NEWS The data in this study have been presented in the framework of a set of provisional periods. The provisional periodization was intended to track trends in the presentation of CBC television newscasts. It was expected that analysis of the statistical results of coding news stories by category within the provisional framework would assist in identifying causes of change (see Figure 1).

FIGURE 1

PROVISIONAL PERIODIZATION

$\begin{array}{lll}\text { Period I } & 1952-1954 & \text { Gestation } \\ \text { Period II } & 1954-1966 & \text { Legitimation and } \\ & & \text { Experimentation } \\ \text { Period III } & 1966-1980 & \text { Expansion } \\ \text { Period IV } & 1980-1988 & \text { Maturation }\end{array}$

However, several problems have emerged with the provisional model of development. The provisional periodization assumed that there would be more change between certain periods than aciually turned out to be the case, at least on the basis of the statistical results. 
First, tl.3 period from 1952 to 1954 was provisionally identified as the gestation period because the news programs were expected to reflect uncertainty about how news should be presented on television. Although there are some differences between the statistical patterns for the three "Tabloid" newscasts from 1953 and the other newscasts from the 1950s, there are enough similarities to indicate that the scheduling of news in its cwn program format in 1954 seems to have had less impact on television news presentation styles than originally anticipated. 80

Secondly, the designation of 1966 as the boundary between the second and third provisional periods presents a difficulty. Some changes that occurred in 1966 in the structure of CBC's television news appear to have had no measurable effect on the presentation of the news. The naming of a CBC reporter as news anchor and the establishment of a team of reporters specializing in a range of subject areas suggest that the CBC saw a need for experimenting with the news format. However, these changes did not result in a change in the on-air role of the anchor

80. The newscasts broadcast as part of the "Tabloid" series were coded using the same categories as the other newscasts in this study. The results were not included in the statistical tables as it was initially felt that the three programs, provisionally placed in their own period, would not constitute a large enough sample. 
or an expansion of the range of story subjec;cs reported. For that matter, the role of the anchor and the subject matter of news stories in the 19808 do not seem to have greatly changed since the 1950s. Most of the presentation elements characteristic of the newscasts produced between 1956 and 1966, during the second provisional period, are also attributes of the newscasts from the early part of the next provisional period, as indicated in the newscasts of 1969 and 1970.

Thirdly, the provisional grouping of newscasts from 1966 to 1980 did not take into account the abrupt change that occurred in presentation styles in the early 19708. In most coding categories, the programs from the 1974 to 1979 period appear to belong to the period of dsvelopment characteristic of the 19808 .

With these points in mind, a more workable perlodization would be as follows (see Figure 2): 
FIGURE 2

REVISED PERIODIZATION

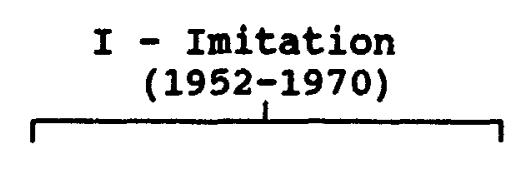

(A)

iegitimation (1952-1959)
(B)

Expansion $(1960-1970)$

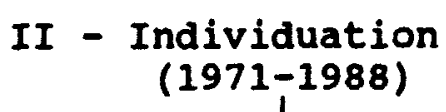

(A) Visualiz. n (19?1-?
(B)

Sophistication (1982-1988)

This revised periodization operates at two levels. First, it identifies two main periods of development: one from 1952 to 1970 and the second covering the 1970 s and the 1980 s. Each of these periods is then divided into two sub-periods in order to reflect certain changes that. occurred within them which were significant, but not as fundamental as those between the two main reriods.

Period I -- Imitation (1952-1970)

The revised periodization identifies 1952 to 1970 as the first main period of development. It was a period in which the dominant feature of CBC television news presentation was its imitation of the style of other media. In this period, CBC television news used visuals largely as a mere accompaniment to verbal information. The visuals were grafted onto the news story and subordinated to the words spoken by the anchor or reporter. Not surprisingly, 
television critics of the period complained that CBC television news was little better than "radio with pictures." In fact, CBC television adopted many of the practices of the $C B C$ radio news service, including the presentation of much of the newscast, made up of a number of brief script-only stories, by a staff announcer.

The influence of the theatrical newsreel was quite apparent in this period, in the style of the relatively small number of filmed stories in the 1950s. Like the newsreels, CBC television news presented its filmed stories with voiceover narration by the anchor and music. Despite this, it seems that radio, rather than the newsreel, was the dominant influence on the presentation of news on CBC television in the Imitation Period. Even in the 1950s, politics constituted the predominant subject matter, rather than the human interest, disaster and crime stories characteristic of the theatrical newsreel.

within this period, however, certain changes did occur. The revised periodization divides the Imitation Period into the sub-periods Legitimation and Expansion.

\section{IA - Iegitimation (1952-1959)}

The 1950s is considered a period of legitimation because during that time $C B C$ television was trying to establish news on the program schedule. News had to compete 
for air time with other types of television programs. It also had to prove itself as a legitimate means of news dissemination in the shadow of the well-respected and established $C B C$ radio news service. The use of film was one way television could gain an advantage over other print media and radio. The newscasts of the 1950 s looked as if the $C B C$ was trying to establish a presence over the airwaves, without doing much to explore the story-telling potential of $€$ ilm. Film of events and interview clips, used less frequently in this period than later, tended to have fewer edits.

In this early period, moreover, the $\mathrm{CBC}$ and its journalists did not yet agree on the role of the reporter. The CBC envisioned that the cameraman would be the principal gatherer of news in the field, in the tradition of the newsreel cameraman. Reporters would gather information by telephone in the newsroom and rewrite wire copy. By the end of the 1950s, the emergence of a small group of television reporters who went out into the field to do original reporting suggests that the $C B C$ was beginning to see its role as an originator of television news reports. IB - Expansj on (1960-1970) The decade of the $1960 \mathrm{~s}$ is characterized as one of expansion because of the increase in the number of reporters 
and the apparent expansion of their role. The greatest difference between the "CBC Television News" programs of the $1950 \mathrm{~s}$ and the newscasts of the $1960 \mathrm{~s}$ is the more frequent appearance by CBC reporters on newscasts of the 1960 . Accompanying the greater presence of reporters in the $1960 \mathrm{~s}$ newscasts is an decrease in the number of basic "who, what, why, where and when" descriptive stories. There is a jump in the number of inferential stories, indicating that the role of the reporter was evolving from an on-camera witness to that of an analyst. The degree to which news stories are inferential is approximately the same in the 1960 to 1966 newscasts and the 1969 to 1970 programs.

Expansion is also true of the use of film. During this period, the $C B C$ continued efforts begun in the 1950 s to improve the means by which it obtained film footage of news events. The increase in the use of film was likely spurred by the establishment in the CBC trans-Canada microwave network in 1958. Given that there were few sequences of film in the sample that could be identified as transmissions from trans-Atlantic satellite, the launch of the communications satellites in 1962 and 1965 apparently had little impact. Nor did CBC's efforts to improve its means of reporting the news visually seem to have boosted the network's ability to cover spontaneous news events. The 
percentage of news stories about spontaneous events is highest in the three Tabloid programs. This suggests that news values and the logistics of booking camera crews and reporters' assignments outweighed technologica? capability in favour of preplanned news stories. Similarly, film footage of spontaneous events is highest in the sample of newscasts from 1953, dropping steadily thereafter.

The provisional periodization anticipated that the 1954 to 1966 period would be characterized by more experimentation than the other developmental periods. It was expected that experimentation would be revealed by attempts to use different formats. "Tabloid" newscasts show some evidence of experimentation. On one program, anchor Gil Christie reads the news while standing up. The other programs show him seated at a desk, in more typical newscast style. The earliest program, apparently a rehearsal show, alternates shots of the anchor reading the story in the studio with snippets of voiceover that accompany several slides. Another program actually shows Christie answering the telephone on his desk and his subsequent passing on to the viewers of the breaking story thus relayed to $\mathrm{him}$. The "Weekend" programs of 1969 and 1970 also played with the standard television news format, having anchor Lloyd Robertson read the news while standing behind a desk 
that slid out from a wall. The "Weekday" programs provide evidence of experimentation in that they are the only newscasts in the sample to use a two-anchor team. The revised periodization does not, however, characterize any of the developmental periods as experimental. There is evidence of format variations throughout the periods, but no single period is typified by an experimental spirit.

Period II -- Individuation (1971-1988)

In contrast with the period of imitation, the second main period of development was characterized by individuation, or the process of forming into a distinct entity. During this period, CBC television news changed from being news broadcast on television to a form of news presentation that was more in tune with the nature and capabilities of television as a medium. Newscasts of the individuation period made more use of television's capacity to visualize news. The pace and visual quality of the newscasts of the individuation period increased noticeably. By 1974, "The National" looked very much like a present-day newscast, with a format that illustrated almost every story with a graphic. CBC Television had by this time acquired the technical capacity to combine the anchor's introduction, stand-up reports by reporters in the field, reporter voiceover, film or videotaped images and interview clips 
into complex narratives which were much more sophisticated than the "radio with pictures" style of the $1950 \mathrm{~s}$ and $1960 \mathrm{~s}$. News stories of the 1950 s and early 1960 s tended to use fewer kinds of visuals, and their illustrations often consisted exclusively of talking head footage. By the 1970s, it was customary for a news story to combine talking head footage with sequences of events as they occurred and more general illustrative footage.

The individuation period is also characterized by a greater attempt to expand television news reporting from the basic report format of news stories. The longer, in-depth "Special Report", introduced on "The National" in the late 1970 s and continued in the 1980s, indicated that the CBC wanted news to be more than an electronic headline service secondary to print or radio news.

Additional changes occurred within the individuation period. To reflect this, the revised periodization is subdivided into the visualization and Sophistication periods.

\section{IIA - - Visualization (1971-1981)}

The statistics for most of the coding categories show the sharpest degree of change by the 1974 to 1979 period, making the newscasts look considerably different from previous programs. There are marked increases in the number of on-screen appearances by reporters in the field, 
inferential reports, and the use of film and videotape. There are abrupt decreases in the number of stories for which no source is indicated, basic reports, stories without any graphics, and the percentage of time for which anchors are shown on screen. During this period, CBC television newscasts begin to look most like present-day programs. IIB - Sophistication (1982-1988)

The decade of the $1980 \mathrm{~s}$ is characterized as a period of growing sophistication because the newscasts continued to explore the unique qualities of videotape and computer graphics to tell stories visually. The main difference between the newscasts of the 1970 s and those of the 1980s is the sophistication of the graphic elements, both in terms of more detailed still images that accompany the shot of the anchor and of animated sequences incorporated into videotaped reports. Computer-generated animation and detailed still-image graphics made it easier to depict economic stories and other abstract subjects visually.

This increasing sophistication seems to have occurred around the time that CBC started broadcasting its weeknight current affairs program "The Journal" in 1982. The use of the term sophistication to characterize the style of CBC television news presentation in the 1980 s should not be construed to suggest that this decade's newscasts are 
superior to earlier programs. The newscasts are termed sophisticated because they are faster-paced and visually more attractive than their predecessors. The tendency to use frequent edits in interviews and visuals increases the degree to which there is mediation between the raw information and the news as packaged to attract and keep viewer attention.

Television, with its ability to show people and events in the news, has the potential to be more direct than print or radio, which channel information through the printed or spoken word. Nevertheless, newscasts that predate the widespread management of news by interest groups in society as well as the technology that makes it easier to edit visuals and sound, may often constitute a more immediate, if less visually exciting means of broadcasting information. Mediation, then, refers to a progression in the reporting of news as a unique form of television program. It does not necessarily imply unqualified progress in the broadcasting of news on television.

The statistical results have been reported according to individual news program formats, to permit the tracking of differences attributable to format variations. This has allowed some statistics to be isolated and the reasons for their variance from a pattern to be explained. For example, the review of events of the previous week on the "CBC News 
Saturday Report" and the panel discussion during the "CBC News Sunday Report", both broadcast in 1988, heip to explain why the coding results for some categories differ somewhat from the trends displayed in the results for "The National" from 1980 to 1988 .

Most of the results for the different coding categories show consistent patterns of increase, decrease or stasis, regardless of different program formats. This suggests that CBC television has produced news programs that tend to be homogeneous in presentation style, within particular time periods.

The value of the methodology of this study, content analysis, resides in its ability to provide observable data on the presentation of television news. It is limited in that it cannot provide detailed explanations for the reasons behind television news presentation style. This study uses analysis of newscasts over time in order use the concept of change to compensate for the tendency of content analysis to become too narrowly focused. In addition, oral histories and published documents have been consulted as guides to the analysis of the data. The data is intended to be useful in further studies on the economic, institutional and ideological factors shaping television news. 


\section{BIBLIOGRAPHY}

\section{Books and Periodicals}

"News Co-op: A Perfect Answer," Canadian Television and yotion picture Reyiew, 1 (No. 12, August-September 1955), 4 .

Adams, Williams and Fay Schriebman, eds. Television Network News: Issues in Content Research, (Washington D.C.: School of Public and International Affairs, George Washington University, 1978).

Aitken, John and Norman Hartley, "Made to Measure," Heekend Magarine, (May 10, 1975), 2-9.

Allen, Rod, "Images Generated Through Electronics," EBU Review, 32 (No. 4, July 1981), 22-26.

Batten, Jack, "The Overdue Overhaul That's Going on in CBC News," Canadian Magazine, (April 16, 1966), 24-25.

Beaudry, Roger, "CBS News and Magnetic Sound," Vision, 3 (No. 3, January 1957), 11, 14.

Boorstin, Daniel, The Image, (New York: Atheneum, 1962).

Braithwaite, Dennis, "CBC News Hit," The Toronto Globe and Mail, March 24, 1967, 25.

Braithwaite, Dennis, "Czar of the News," The Toronto Globe and Mail, March 8, 1966, 31.

Braithwaite, Dennis, "Glimpsed New Look," The Toronto Globe and Mail, March 14, 1966, 21.

Braithwaite, Dennis, "News Without Earl," The Toronto Globe and Mail, December 14, 1966, 29.

Braithwaite, Dennis, "No Visual Vision," The Toronto Globe and Mail, February 2, 1966, 27.

Braithwaite, Dennis, "Radio with Pictures," The Toronto

Globe and Mail, September 8, 1964, 27.

CBC. Annual Reports, (1952 -- ). 
Audience Attitudes and Reactions to the rate Night National Newscasts on the CBC Fnglish TV Network and CTV Network, (Toronto: CBC, May 1972).

The CBC -- A Perspective, (Ottawa: CBC, May 1978).

CBC News style Book, (CBC, 1971).

CBC News Directives and style Guide, (CBC, March 1961), n.p.

Journalistic Policy, (Ottawa: CBC, July 1982).

The Late-Night Newscasts of the CBC, CTV and TVA

Networks: Who Watches Them and How are They Perceived?, (Ottawa: CBC, August 1977).

"A New Agency to speed World Coverage for the CBC-TV News Service," CBC Times, (March 31-April 6, 1957), 12.

"Tabloid: Daily Actualities on CBC-TV," CBC Times, (July 5-11, 1953), 3-4.

Cayer, Jacques, "studio 750 the First of its Kind," TVRadio, 19 (No. 10, November-December 1963), 17-19.

Collins, Richard, Television News, (London: British Film Institute, 1975).

Dahlgren, Peter, "TV News as a social Relation," Media, culture, and Society, 3 (No. 3, July 1981), 291-302.

Dahlgren, Peter, "The Modes of Reception: For a Hermeneutics of TV News," in eds. P. Drummond and R. Paterson, Television in Transition, (London: British Film Institute, 1985), 235-249.

DePoe, Norman, "The Failure of TV News," In Fescch, 4 (No. 3, Summer 1977), 14-18.

Duckworth, Frank, "For Canadians: Fast Coverage of world on Television," TV News Weekly, (May 4, 1957), 44-46.

Eaman, Ross A, The Media Society: Basic Issues and Controversies, (Toror: Lo: Butterworths, 1987).

Epstein, Edward Jay, News from Nowhere Television and the Nerks, (New York: Vintage Books, 1974). 
Fiske, John, Television Culture, (New York: Methuen, 1987).

Fiske, John and John Hartley, Reading Televigion, (London: Methuen, 1978).

Glasgow University Media Group, Bad News, (Boston: Routledge and Kegan Paul, 1976).

Glasgow University Media Group, Yore Bad News, (Boston: Routledge and Kegan Paul, 1980).

Gzowski, Peter, "The Sheer Boredom of SBC's News," Maclean's Magazine, (February 5, 1966), 43.

Hackett, Robert, "The Depiction of Labour and Business on National Television News," Canadian Journal of Communication, 10 (No. 1, winter 1983), 5-50.

Hartley, John, Understanding News, (London: Methuen, 1983).

Heath, Harry E. Jr., "News by Television: A Review of Practices and Possibilities," Journalism Quarterly, 27 (Fall 1950), 404-418.

Kiefl, Barry, Happy Medium A Content Analysis of Network Television News, (Ottawa: CBC, 1978).

Kirby, Blaik, "Grumblings in the CBC TV News," The Toronto Globe and Mail, August 27, 1973, 15.

Sline, stephen, "National Perspective and News Bias: A Comparison of National News Broadcasts," Canadian Journal of Communication, 7 (No. 4, March 1981), 47-70.

Knight, Graham, "News and Ideology," Canadian Journal of communication, 8 (No. 4, September 1982), 15-41.

Lewis, Justin, "Decoding Television News," in eds. P. Drummond and $R$. Paterson, Television in Transition, (London: British Film Institute, 1985), 205-333.

McCall, Christina, "The Man Behind Canadian TV's Most Famous Face," Maclean's Magazine, (September 27, 1958), 15, 56-60.

McEwen, Daniel, "Twenty Years Behind the Screens," Broadcaster, 37 (No. 10, October 1978), 14-16. 
Mickelson, Sig, "Growth of Television News, 1946-1957," Journalism Quarterly, 34 (Summer 1957), 304-310.

Nash, Knowlton, History on the Run: The Trenchcoat Komoirs of a Foreign Correspondent, (Toronto: McClelland and stewart, 1984).

Nash, Knowlton, Prime Time at Ten: Behind-the Camera Battles of Canadian TV Journalism, (Toronto: McClelland and stewart, 1987).

National Archives of Canada (hereafter NA), Beyond the Printed jord Newsreel and Broadcast Reporting in Canada, (Ottawa: Minister of Supply and Services Canada, 1988).

Robinson, Gertrude Joch, "Television News and the Claim to Facticity: Quebec's Referendum Coverage," in eds. Willard D. Rowland $\mathrm{Jr}$. and Bruce Watkins, Interpreting Television: current Research Perspectives, (Beverly Hills, California: Sage Publications, 1984), 199-221.

Schudson, Michael, "The Politics of Narrative Form: The Emergence of News Conventions in Print and Television," Daedalus, 3 (No. 4, Fall 1982), 97-112.

Sinclair, Gordon, "Radio and Television," The Toronto star, February 28, 1953, 5 .

Smith, Robert Rutherford, "Mythic Elements in Television News," Journal of communication, 29 (No. 1, winter 1979), 75-82.

Sperry, Sharon Lynn, "Television News as Narrative," in eds. Richard Adler and Douglass Cater, Television as a Cultural Force, (New York: Praeger Publishers, 1976), 129-146.

Stam, Robert, "Television News and its spectator," in ed. E. Ann Kaplan. Regarding Television: Critical Approaches An Anthology, (Los Angeles: University Publications of America Inc./The American Film Institute, 1983), 23-43.

steinberg, Ned, "Television Graphics in CBS News," EBU Review, 32 (No. 4, July 1981), 27-28.

Sutton, Bruce, "They are Building a New Canadian Industry," Radio, (February 1954), 4-7, 19. 
Troyer, Warner, The Sound and the Fury: An Anecdotal History of Canadian Broadcasting, (Toronto, Personal Library, 1982).

Trueman, Peter, smoke and Mirrors: The Inside story of Television News in Canada, (Toronto, McClelland and stewart, 1980).

Tuchman, Gaye, Making News: A study in the construction of Reality, (New York: Free Press, 1978).

Weir, E. Austin, The struggle for National Broadcasting in Canada, (Toronto: Mccleliand and Stewart, 1965).

Westell, Anthony, "Reporting the Nation's Business," in ed. G. Stuart Adam, Journalism, Communication and the Law, (Scarborough, Ontario: Prentice-Hall of Canada Limited, 1976).

\section{Audio-Visual sources}

All recordings 1 isted as follows are in the Moving Image and Sound Archives (MISA) of the National Archives of Canada (NA) :

\section{f.udiotape}

Moving Image and Sound Archives Collection:

Beyond the Printed Word Symposium: Then and Now: Presenting and Delivering the News Report, October 20, 1988 .

\section{Videotape}

Canadian Broadcasting Corporation Collection:

CBC News Saturday Report, March 26, 1988.

CBC News Sunday Report, March 27, 1988.

CBC Teleyision News Evening Edition, March 13, 14, 15, 16 and 17,1961 .

CBC Television News National Edition, March 31 and May 16, 1960; March 12, 13, 14, 15, 16, and 17, 1961; January 31 and April 4, 1963; April 25, 1964; July 27, August 9, and October 26, 1965; January 20 and March 13, 1966. 
The National, October 11 and 25, 1970; March 19, 1974 ; November 20, 1975; January 14, 1977; June 16, 1978 ; November 13, 1979; Apri1 22 and December 23, 1980; March 6, 1981; January 11 and December 18, 1982; January 19 and May 5, 1983; February 8 and August 12, 1984; January 14 and December 12, 1985; February 5, 1986; February 26, 1987; October 4, 1988.

Tabloid, February 27, March 18, and March 31, 1953.

Weekday, October 1 and December 17, 1969: January 12, 13 and 14, 1970: June 4, 1970.

Weekend, November 23, 29, December 21 and 28, 1969 ; January 25, February 15, March 1, 8, 15 and 22, April 5 and 12, Kay 3, June 7, August 16, September 27 and October 4, 1970.

Carleton University collection:

The National, May 19, 1977.

Frank stalley collection:

CBC Television News Evening Edition, September 19, 1956; May $10,1957$.

Société Radio-Canada Collection:

CBC Evening News, October 1, 1963.

Stanley Burke Collection:

CBC National News, Algust 8, 1969.

Audiotape Interviews:

All interviews are from the carleton University Institute of Canadian studies Collection at MISA:

Kenneth Brown by Ron Hallam, 9 December 1981.

Bill Cunningham by Ross Eaman, 19 May 1983.

Tom Earle by Paul Follis, 25 February anc 2 March 1982.

Gordon Glynn by Ron Hallam, 10 and 15 April 1982.

Ray Hazzan by Paul Follis, 31 May 1982. 
Leslie Jackson by Ross Eaman, 6 June 1983.

Reginald Jessup by Ross Eaman, 6 June 1983.

Larry MacDonald by Paul Follis, 15 February 1982.

Peter Mansbridge by Caroline Jondahl, 19 February 1988.

Bill Morgan by Caroline Jondahl, 19 February 1988.

Knowlton Nash by Ross Eamar, 17 and 18 May 1383.

Knowlton Nash by Caroline Jondahl, 19 February 1988.

John Owen by Caroline Jondahl, 15 February 1988.

Jean Pouliot by Ross Eaman, 27 May 1983.

Lamont Tilden by Ross Eaman, 4 August 1982. 

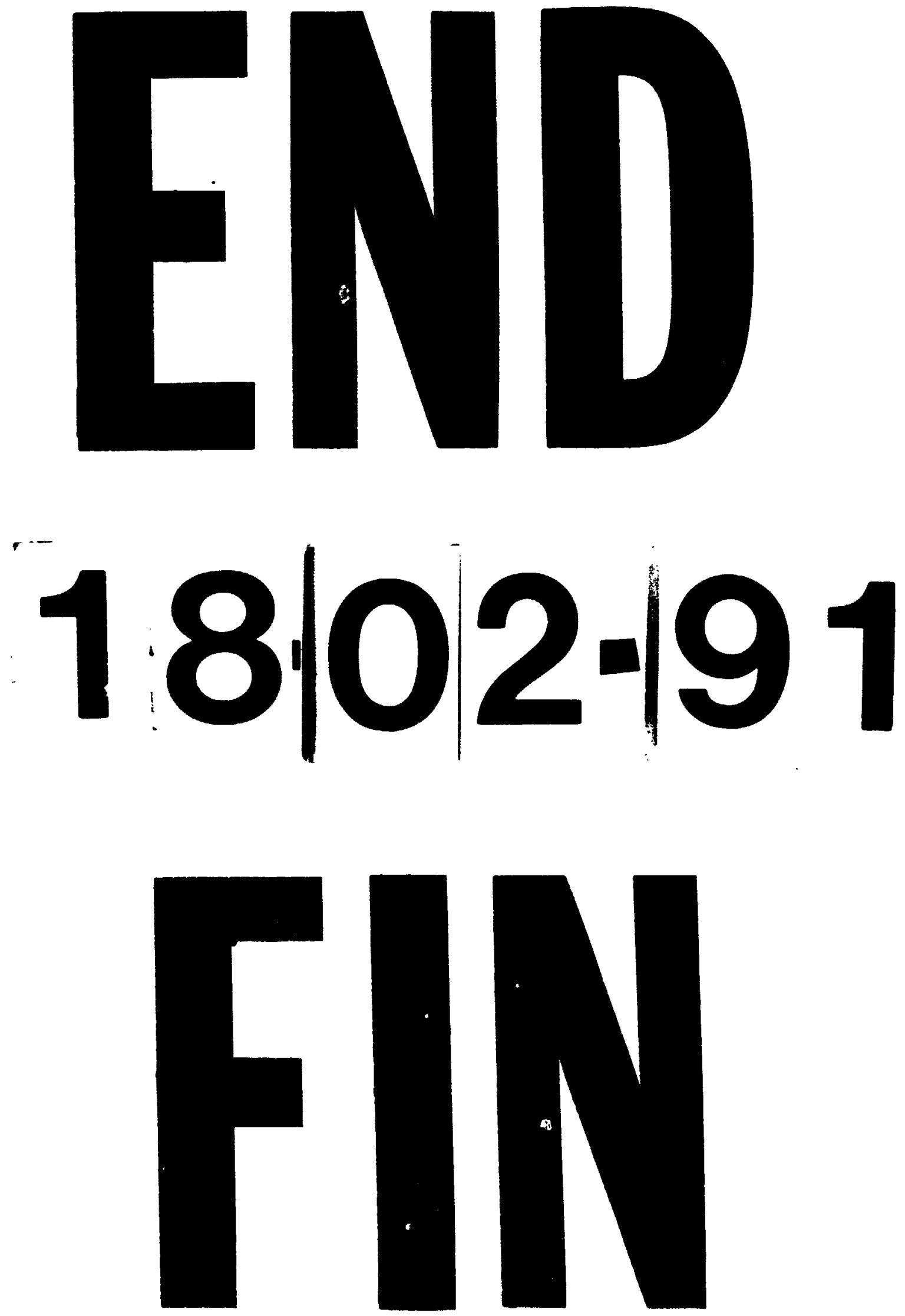